\title{
Review of the Early and Middle Jurassic erymid lobsters (Crustacea: Decapoda)
}

\author{
Julien Devillez ${ }^{1,2, *}$ and Sylvain Charbonnier ${ }^{1,2}$ \\ ${ }^{1}$ Muséum national d'Histoire naturelle, Paris, France \\ ${ }^{2}$ Centre de Recherche en Paléontologie-Paris (CR2P, UMR 7207), Sorbonne Université, MNHN, UPMC, CNRS, 57 rue Cuvier F-75005 \\ Paris, France
}

Received: 28 February 2019 / Accepted: 9 April 2019

\begin{abstract}
Erymid lobsters (Crustacea, Decapoda, Erymidae) are an important component of Mesozoic crustacean faunas in Europe, especially during the Jurassic. The 29 species reported from the Early and Middle Jurassic are the oldest found in Western Europe and North America, and constitute an important part of the evolutionary history of these lobsters. After the review presented here, 24 species are maintained within the genera Eryma Meyer, 1840 ( 7 species), Palaeastacus Bell, 1850 ( 5 species), Pustulina Quenstedt, 1858 ( 2 species) and Stenodactylina Beurlen, 1928 ( 9 species). All these species, with the exception of Eryma ventrosum (Meyer, 1835), have a new description and the diagnoses of the genera Eryma, Palaeastacus and Stenodactylina are emended. Four species are transferred to another genus: Palaeastacus numismalis (Oppel, 1862) n. comb., Palaeastacus foersteri (Feldmann, 1979) n. comb. and Stenodactylina guisei (Wright, 1881) were previously assigned to Eryma, and Stenodactylina spinosa (Étallon, 1861) n. comb. was previously assigned to Palaeastacus. Our study shows that Stenodactylina was the most diversified genus in Early-Middle Jurassic, but the fossils of Eryma are more common. Furthermore, Eryma compressum (Eudes-Deslongchamps, 1842) is the emblematic species of Erymidae Van Straelen, 1925 during the end of Early Jurassic and Middle Jurassic in Western Europe (Toarcian - Bathonian). This species includes now Eryma bedeltum (Quenstedt, 1858) in its synonymy. The genus Pustulina is very rare and the specimens show some characteristics on their carapace recalling other erymid genera (an almost sinuous hepatic groove for example), that are absent in more recent species. Finally, we point out that only E.compressum, P.foersteri and Stenodactylina walkerae (Feldmann and Haggart, 2008) are reported outside Europe.
\end{abstract}

Keywords: Erymidae / lobster / Mesozoic / North America / palaeobiodiversity / Western Europe

Résumé - Révision des Érymides (Crustacea: Decapoda) du Jurassique inférieur et moyen. Les érymides (Crustacea, Decapoda, Erymidae) sont une composante importante des faunes de crustacés au Mésozoïque en Europe, et tout particulièrement au Jurassique. Les 29 espèces d'érymides recensées au Jurassique inférieur et moyen sont les plus anciennes d'Europe occidentale et d'Amérique du Nord, et représentent donc un important volet de l'histoire évolutive du groupe. Le travail de révision présenté ici maintient la validité de 24 espèces appartenant aux genres Eryma Meyer, 1840 (7 espèces), Palaeastacus Bell, 1850 (5 espèces), Pustulina Quenstedt, 1858 (2 espèces) et Stenodactylina Beurlen, 1928 (9 espèces). Toutes ces espèces, à part Eryma ventrosum (Meyer, 1835), bénéficient d'une nouvelle description et les diagnoses des genres Eryma, Palaeastacus et Stenodactylina sont émendées. Quatre espèces ont été transférées au sein d'un autre genre: Palaeastacus numismalis (Oppel, 1862) n. comb., Palaeastacus foersteri (Feldmann, 1979) n. comb. et Stenodactylina guisei (Wright, 1881) étaient auparavant des représentants d'Eryma, et Stenodactylina spinosa (Étallon, 1861) n. comb. appartenait au genre Palaeastacus. Nous constatons que Stenodactylina est le genre le plus diversifié au Jurassique inférieur et moyen, mais Eryma est celui pour lequel le plus de fossiles sont connus. Eryma compressum (EudesDeslongchamps, 1842) est d'ailleurs l'espèce d'Erymidae Van Straelen, 1925 emblématique de la fin du Jurassique inférieur et du Jurassique moyen d'Europe occidentale (Toarcien-Bathonien), et inclut

\footnotetext{
*Corresponding author: julien.devillez@edu.mnhn.fr
} 
désormais Eryma bedeltum (Quenstedt, 1858) dans sa synonymie. Le genre Pustulina est quant à lui très rare et les spécimens ont une carapace qui présente des caractéristiques que l'on n'observe pas sur les formes plus récentes, qui évoquent les autres genres d'érymides (un sillon hépatique presque sinueux par exemple). Enfin, nous constatons que seuls E.compressum, P.foersteri et Stenodactylina walkerae (Feldmann et Haggart, 2008) sont présents en dehors de l'Europe.

Mots clés : Erymidae / homard / Amérique du Nord / Europe occidentale / Mésozoïque / paléobiodiversité

\section{Introduction}

Erymid lobsters are an important component of the decapod faunas during the Mesozoic. They are reported in Europe (e.g., Mantell, 1833; Bell, 1850, 1863; Oppel, 1861, 1862; Lahusen, 1894; Van Straelen, 1925; Beurlen, 1928; Glaessner, 1931; Reuss, 1854; Bachmayer, 1959; Förster and Rieber, 1982; Garassino, 1996; Jagt and Fraaije, 2002; Garassino and Krobicki, 2002; Bravi et al., 2014), in the Middle East (Roger, 1946; Förster and Seyed-Emami, 1982; Garassino, 1994; Charbonnier et al., 2017), in Africa (Beurlen, 1933; Joleaud and Hsu, 1935; Secrétan, 1964, 1984; Charbonnier et al., 2012), in North America (Rathbun, 1923, 1926; Stenzel, 1945; Feldmann and McPherson, 1980; Aguirre-Urreta and Ramos, 1981; Aguirre-Urreta, 1982, 1989; Schweitzer and Feldmann, 2001; Feldmann and Titus, 2006; Feldmann and Haggart, 2008; Vega et al., 2013; J. Luque, pers. com.), in Japan (Karasawa et al., 2008; Kato et al., 2010), in Australia (Woodward, 1877; Etheridge, 1914; Woods, 1957), and in Antarctica (Taylor, 1979; AguirreUrreta, 1989). Despite this worldwide distribution, the fossil record of erymid lobsters remains sparse and fragmentary and the representatives from the Jurassic were not revised since the study of Förster (1966), so the history of this group of lobsters is difficult to reconstruct.

Currently, twenty-nine species are reported in the Early and Middle Jurassic. This is the oldest erymid fauna of the Mesozoic, so it is important to have a clear idea of the diversity of these lobsters during this period to improve our understanding of the evolutionary history of the group. Considering the recent studies which tried to clarify the concepts of erymid genera and proposed new diagnoses (Hyžný et al., 2015; Devillez et al., 2016, 2017; Devillez and Charbonnier, 2017), the present contribution aims to give a new look on Early and Middle Jurassic erymid species, which benefit of new descriptions.

\section{Material and methods}

The studied material includes 114 specimens from the Early and Middle Jurassic, mainly from the palaeontological collections of some European institutions (Tab. 1). Most of them consist of isolated and incomplete carapaces or first chelipeds. However, there are some cases of preservation in compression of specimens more or less complete, from 1) the Sinemurian of Osteno, Italy; 2) the Bajocian-Bathonian of Monte Fallano, Italy; and 3) the Callovian of Brush Canyon, United States.

Most of the characters used in generic and specific identifications of the erymid lobsters are located on the carapace. Indeed, the grooves, their trajectories and their connections, and the ornamentation are the most useful characters used in the recent works on these lobsters (Devillez et al., 2016, 2017; Devillez and Charbonnier, 2017; Fig. 1A). Moreover, the relative extension and the eventual inflation of the some regions, mapped on Figure 1B, are also considered in this study.

In extant lobsters, P1 chelae are laterally inclined, so the palms are almost in the horizontal plan. Thus, in this configuration the occlusal openings are in the horizontal plane. In this paper we follow this natural configuration for the description of the chelae: the palms are the widest sides and correspond to the ventral and dorsal surfaces of the chelae; similarly, the longitudinal margins correspond to inner and outer margins with dactylus located on the inner margin and index on the outer margin (Fig. 1C). Most of the time in erymid lobsters, the fingers are curved downside in lateral view.

\section{Systematic palaeontology}

\author{
Malacostraca Latreille, 1802 \\ Decapoda Latreille, 1802 \\ Erymida sensu Schram and Dixon, 2004 \\ Superfamily Erymoidea Van Straelen, 1925 \\ Family Erymidae Van Straelen, 1925
}

\subsection{Genus Eryma Meyer, 1840a}

(Fig. 2A-C)

Eryma Meyer, 1840a: 587.-Oppel, 1862: 20.-Zittel, 1885: 693.-Méchin, 1901: 74.-Van Straelen, 1925: 233. -Rathbun, 1926: 127.-Secrétan, 1964: 61.-Förster, 1966: 88. - Glaessner, 1969: 455. - Aguirre-Urreta and Ramos, 1981: 610.-Secrétan, 1984: 516.-Aguirre-Urreta, 1989: 513.-Crônier and Courville, 2004: 1004.-Feldmann and Titus, 2006: 63. - Feldmann and Haggart, 2008: 1792. - Hyžný et al., 2015: 375. - Feldmann et al., 2015: 1. - Devillez et al., 2016: 518. - Devillez and Charbonnier, 2017: 3.

Bolina Münster, 1839 sensu Étallon (1859: 192; non Mertens, 1833).

Klytia Meyer, 1840b: 19.-Glaessner, 1969: 456.

Protoclytiopsis Birshtein, 1958: 477.-Förster, 1966: 86. - Feldmann et al., 2015: 10.

Galicia Garassino and Krobicki, 2002: 55.-Feldmann et al., 2015: 3.

Clytia-Beurlen, 1928: 165.

Type species.-Macrourites modestiformis Schlotheim, 1822, by subsequent designation of Glaessner (1929). 


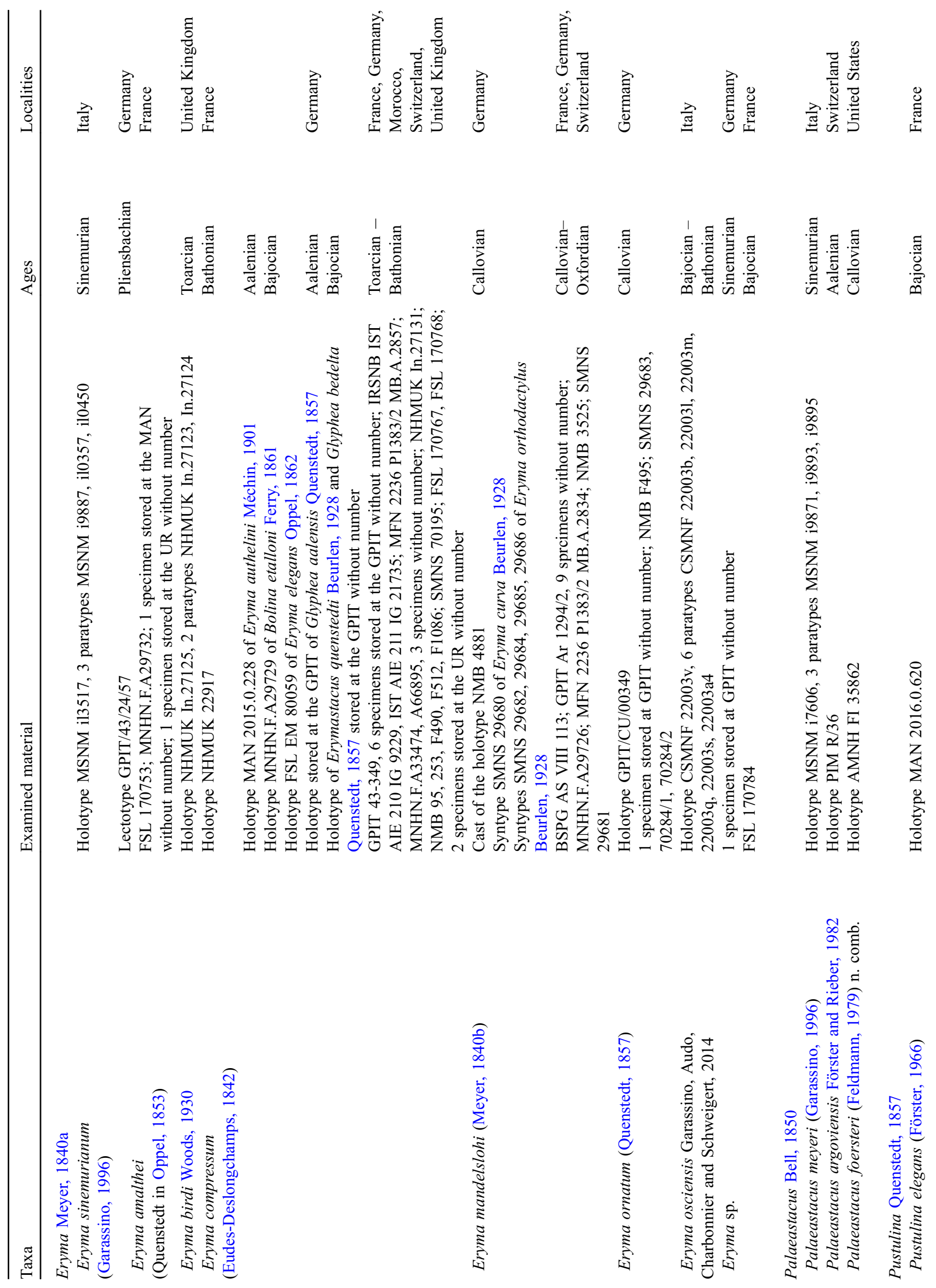




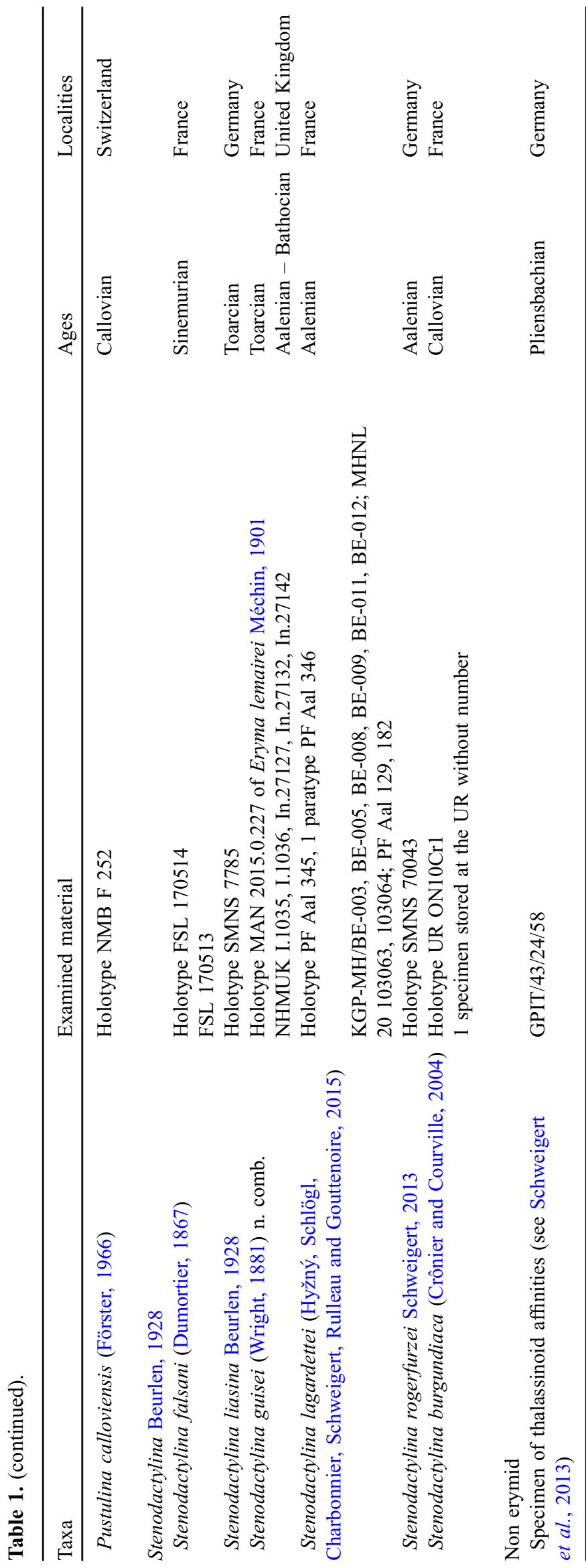

Emended diagnosis. - Fusiform intercalated plate; deep cervical groove, strongly inclined dorsally, joined to dorsal margin and to antennal groove; short gastro-orbital groove, originating as a slight median inflexion of the cervical groove; postcervical groove joined to branchiocardiac groove at carapace mid-height; branchiocardiac groove usually strongly inclined, joined to the posterior extremity of hepatic groove; hepatic groove concavo-convex, joined to cervical groove; inferior groove convex posteriorly, joined to hepatic groove and to ventral margin; $\omega$ area usually inflated; cephalic region usually with an orbital row and with strong orbital and antennal spines; chelate P1-P3; P1 chelae without prominent spines and with an homogeneous ornamentation; $\mathrm{P} 1$ propodus compressed dorso-ventrally with narrow inner and outer margins, with a narrow dactylar bulge; P1 fingers usually longer than propodus, equal in length, progressively narrowing to their distal extremity; index wider than dactylus; P1 chelae (form I; Fig. 2B) with a short rectangular propodus, straight fingers, slightly longer than propodus; P1 chelae (form II; Fig. 2C) with an elongated subrectangular or trapezoidal propodus, bearing fingers quite longer than propodus, usually curved inward.

Discussion.-In the literature, some fossils found in Western Europe and North America were wrongly assigned to Eryma. Indeed, as suggested by Förster (1966), Eryma bordenensis (Copeland, 1960) from the Sinemurian of Canada has a carapace groove pattern typical of Pseudoglyphea Oppel, 1861: gastro-orbital groove with two long and divergent branches, postcervical and branchiocardiac grooves very close, postcervical groove inflected towards its ventral extremity, convergent with the branchiocardiac groove, hepatic groove biconcave. Later, Feldmann and Copeland (1988) described Eryma ollerenshawi on the basis of a fossil found in the Upper Pliensbachian of Canada (Schweigert et al., 2003). The carapace is not preserved on the specimen, but the morphology of the P1 chelae, exhibiting very wide fingers strongly rounded in shape and an elongated subrectangular propodus, does not correspond to an Erymoidea. In a complete study of the lobster genus Uncina Quenstedt, 1851, Schweigert et al. (2003) clearly established the strong similarities between the P1 chelae of Feldmann and Copeland's species and those of Uncina posidoniae Quenstedt, 1851. So, they righteously assigned E. ollerenshawi to Uncina. From the Early Jurassic of United Kingdom, Glyphea macromuscula Feldmann and Schweitzer, 2013 was transferred to Eryma in Charbonnier et al. (2013) because of its truly chelate P1. However, the presence of cephalic carina, the sinuous antennal groove and the hepatic groove biconcave are not features found in Erymoidea, so it is not an erymid lobster. Eryma squalidum Étallon, 1861 (Callovian, France) was described on the basis of an isolated P1 chela currently lost. The trapezoidal propodus is almost twice as long than wide and is slightly globose. This shape is not characteristic of that of the P1 of any erymid lobster. This species is then considered as incertae sedis. Finally, Eryma romani Oppel, 1861 (Callovian, Germany) is known by a carapace preserved in connection with the pléon and a $\mathrm{P} 1$. The $\mathrm{P} 1$ propodus is very stout, as wide as carapace height and very short. The carapace grooves are weakly marked and the pleonal pleurites are wide and rounded. According to Förster (1966), 


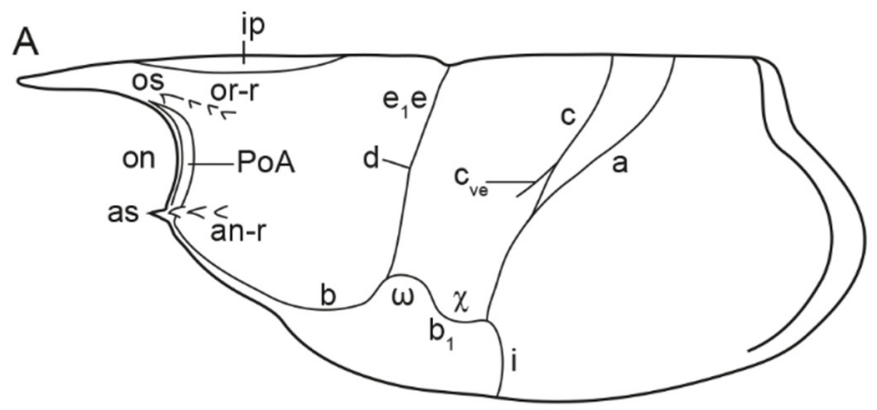

B

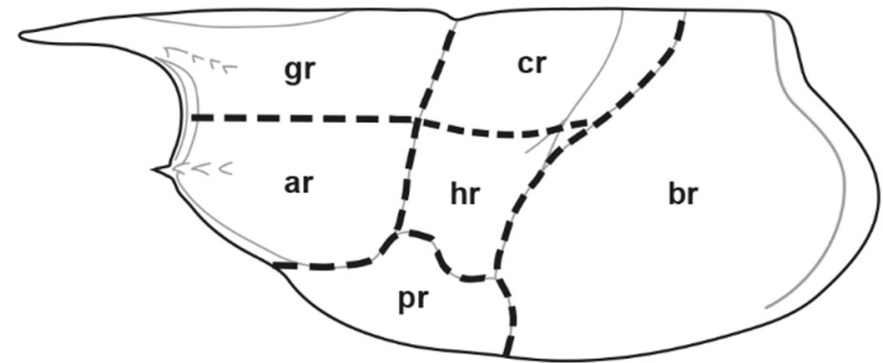

C

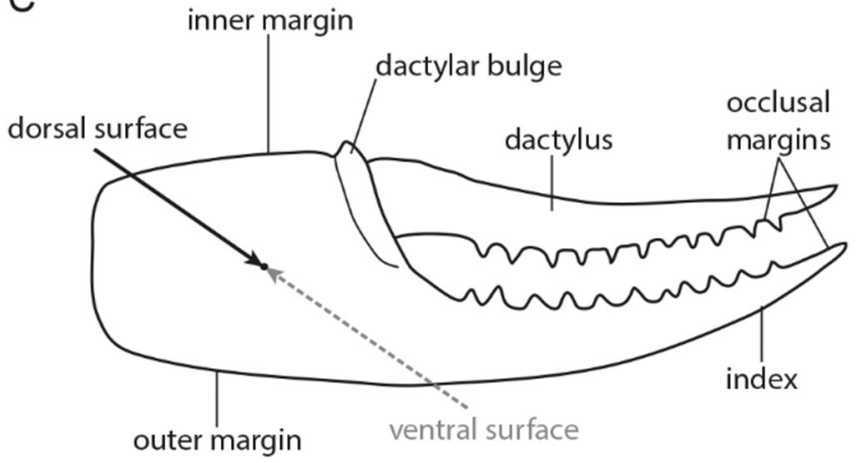

Fig. 1. Terminology applied to the carapace and chela of the first pair of pereiopods. A: grooves, ornamentation and structures commonly found in erymid lobsters; $\mathrm{B}$ : regions of the carapace; $\mathrm{C}$ : morphology of a chela of the first pair of pereiopods. Abbreviations: a: branchiocardiac groove; an-r: antennal row; ar: antennal region; as: antennal spine; $b$ : antennal groove; $b_{1}$ : hepatic groove; br: branchial region; c: postcervical groove; $\mathrm{c}_{\mathrm{ve}}$ : ventral extension of the postcervical groove; cr: cardiac region; d: gastro- orbital groove; $\mathrm{e}_{1} \mathrm{e}$ : cervical groove; gr: gastric region; hr: hepatic region; i: inferior groove; ip: intercalated plate; on: orbital notch; or-r: orbital row; os: orbital spine; PoA: post-orbital area; pr: pterygostomial region; $\chi$ : attachment site of adductor testis muscle; $\omega$ : attachement site of mandibular muscle. Line drawings: J. Devillez.

such characteristics correspond to the representatives of Magila Münster, 1839.

\subsection{Eryma sinemurianum (Garassino, 1996)}

Fig. 2D-G

Phlyctisoma sinemuriana Garassino, 1996: 338, fig. 145 $\mathrm{n}^{\mathrm{o}}$ 18-21.-Monaco and Garassino, 2000: fig. 4.

Pustulina sinemuriana-Schweitzer et al., 2010: 26.
Eryma sinemuriana-Devillez and Charbonnier, 2017: 6, tab. 1, fig. 3c-d.-Devillez et al., 2018: 146.

Type material. - Holotype MSNM i13517; three paratypes MSNM i9887, i10357, i10450.

Type locality. - Osteno, Lombardy, Italy.

Type age. - Sinemurian, Early Jurassic.

Description.

Carapace.-Sub-cylindrical carapace; elongated rostrum, without spines; deep, wide cervical groove, almost straight, joined to dorsal margin; short, shallow gastro-orbital groove, joined to cervical groove at carapace mid-height; postcervical and branchiocardiac grooves convergent, joined at the level of gastro-orbital groove, not joined to dorsal margin; postcervical groove almost straight and subvertical; branchiocardiac groove strongly inclined.

Pleon and uropods. - Somites with subtriangular pleurites, with a slightly inflated and elongated bulge on their basis; rounded telson, with two longitudinal crests along lateral margins; wide, rounded uropods, as long as telson; uropodal endopods with a longitudinal carina; uropodal exopods with a diaeresis, and with a longitudinal carina.

Cephalic appendages. - Small eyes; wide antennal basipodite; wide, trapezoidal scaphocerite.

Thoracic appendages. - Elongated Mxp3; chelate P1; P1 propodus subrectangular; elongated $\mathrm{P} 1$ fingers, equal in length, progressively narrowing to their distal extremity, curved inward; P1 carpus short, subtriangular; elongated P1 merus; thin P2-P4; P2 chelate.

Ornamentation.-Carapace densely covered by small depressions; pleonal tergites and pleurites covered by small depressions; telson covered by small depressions, and with a strong tubercle in proximal part of longitudinal crests; uropods covered by small depressions; $\mathrm{P} 1$ propodus and carpus covered by small depressions; P2-P5 covered by small and widely spaced depressions.

Discussion. - Eryma sinemurianum is only known by a few number of specimens. Their preservation in compression makes difficult the observation of the carapace grooves. Initially assigned to Pustulina Quenstedt, 1858, Devillez and Charbonnier (2017) have integrated E. sinemurianum to Eryma. This new generic assignation is supported by the presence of a junction between postcervical and branchiocardiac grooves, a short gastro-orbital groove, and by the shape of P1 chelae (subrectangular propodus, elongated and thin fingers, progressively narrowing to their distal extremity, curved inward).

The compression of the specimens of Eryma sinemurianum makes difficult the comparisons with the other species of Eryma. The curved fingers of E. sinemurianum are distinct from the straight fingers of E. mandelslohi and E. osciensis. The ornamentation of E. sinemurianum is only made of depressions contrary to E. birdi, E. compressum, E. ornatum, E. osciensis and E. ventrosum which are ornamented by tubercles.

\subsection{Eryma amalthei (Quenstedt in Oppel, 1853)}

Fig. 3A-B, E-H

Glyphea amalthei Quenstedt, 1854: 196.-Étallon, 1861: 170, pl. 8, fig. 3 . 


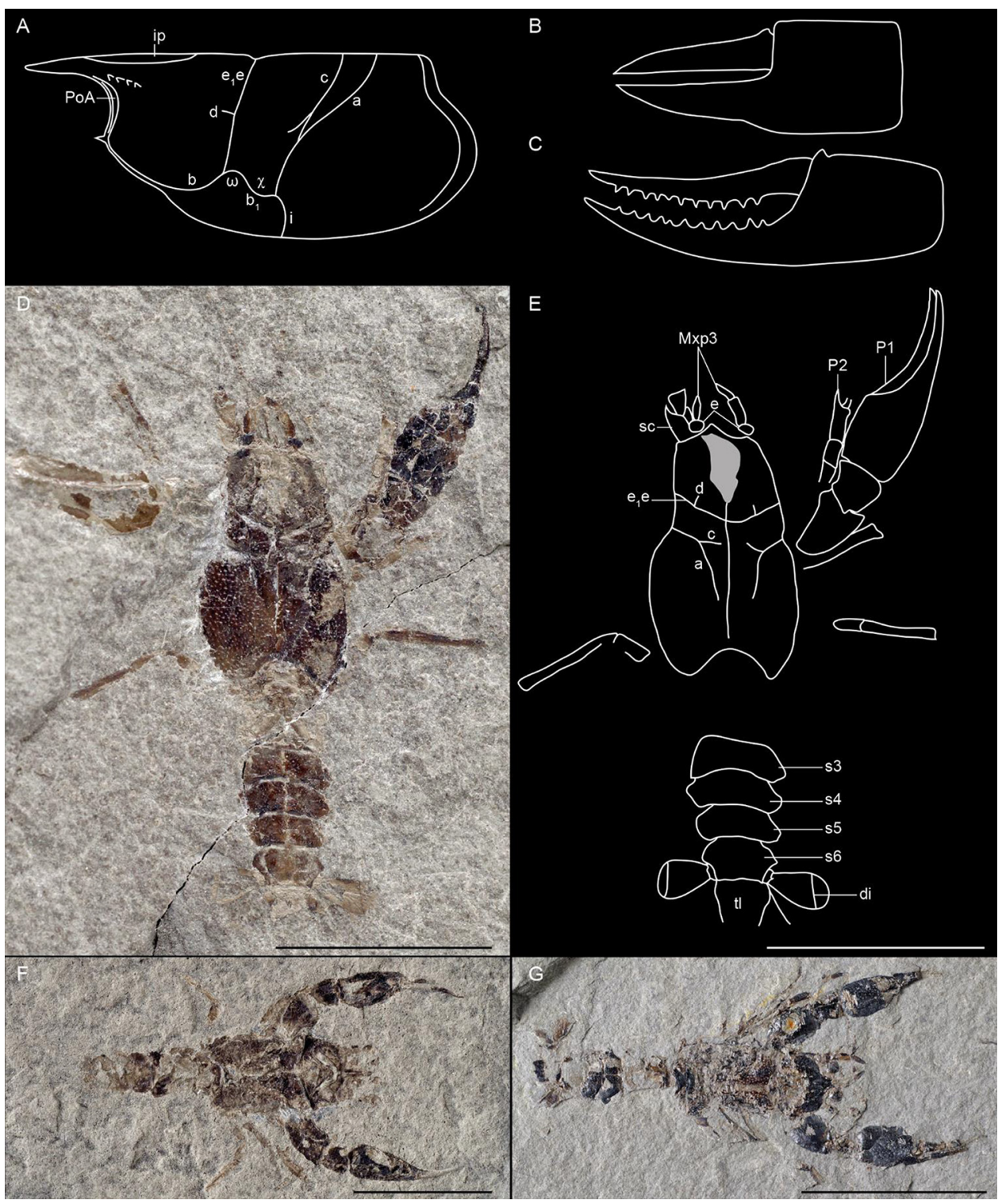

Fig. 2. Morphology of the carapace and of the chela of the first pair of pereiopods of Eryma Meyer, 1840a and Eryma sinemurianum (Garassino, 1996). A: typical carapace groove pattern of Eryma; B: form I of chela of the first pair of pereiopods of Eryma; C: form II of chela of the first pair of pereiopods of Eryma; D-E: holotype MSNM 13517 of Eryma sinemurianum from the Sinemurian of Osteno (Italy): general view (D), line drawing (E); F: paratype MSNM il7608 of E. sinemurianum, G: paratype MSNM i10450. Scale bars: $1 \mathrm{~cm}$. Abbreviations: a: branchiocardiac groove; $b$ : antennal groove; $b_{1}$ : hepatic groove; $c$ : postcervical groove; d: gastro-orbital groove; di: diaeresis; e: eyes; $e_{1} e$ : cervical groove; i: inferior groove; ip: intercalated plate; Mxp3: third maxillipeds; P1-2: pereiopods; PoA: post-orbital area; s3-6: pleonal somites; sc: scaphocerite; tl: telson; $\chi$ : attachment site of adductor testis muscle; $\omega$ : attachement site of mandibular muscle. Photographs: A. Garassino. Line drawings: J. Devillez.

Eryma laedonensis Étallon, 1861: 169. - Oppel, 1861: 356; 1862: 25.-Morière, 1888: 143.-Van Straelen, 1925: 235.-Glaessner, 1929: 162.-Schweitzer et al., 2010: 23.

Eryma propinqua Oppel, 1862: 24, pl.4, fig. 6.-Carter, 1886: 549.-Méchin, 1901: 79, fig. 1.-Van Straelen, 1925: 234, fig. 110.-Secrétan, 1964: 69.-Schweitzer et al., 2010: 23.

Eryma amalthea-Oppel, 1862: 24.-Förster, 1966: 91, fig. 13, pl. 13, figs. 4-6.-Feldmann, 1979: 4.-Crônier and Courville, 2004: 1006, 1007.-Etter, 2004: 384.
Eryma amalthei-Van Straelen, 1925: 236.-Secrétan, 1964: 69.-Schweitzer et al., 2010: 23.-Schweigert et al., 2013: 806, 809, Fig. 8A-B.

Clytia propinqua-Beurlen, 1928: 165, 166, 167.-Glaessner, 1929: 117.

Clytia amalthea-Beurlen, 1928: 167, 168, pl. 7, figs $15-17$.

Clytia amalthei-Glaessner, 1929: 114.

Eryma cf. amalthea (pars.)-Förster, 1966: 94, pl. 13, fig. 3 . 
Type material. - Lectotype GPIT/43/24/57, designated by Förster (1966) .

Type locality.-Holzmaden, Baden- Württemberg, Germany.

Type age. - Late Pliensbachian, Early Jurassic.

Description.

Carapace.-Sub-cylindrical carapace; fusiform intercalated plate; branchial region short dorsally; deep, wide cervical groove, curved dorsally, strongly inflected at carapace midheight, joined to dorsal margin and to antennal groove; deep, narrow antennal groove; short, deep gastro-orbital groove, originating as a median inflexion of cervical groove; shallow narrow postcervical groove, slightly curved, not joined to dorsal margin and joined to branchiocardiac groove at the level of gastro-orbital groove; shallow branchiocardiac groove, becoming deeper toward its junction to hepatic groove, subparallel to postcervical groove, strongly inflected at carapace mid-height, not joined to dorsal margin and joined to hepatic groove; shallow, narrow hepatic groove, concavoconvex, joined to cervical groove; flat $\omega$ and $\chi$ areas; deep, wide inferior groove.

Pleon and uropods. - Somites with subtriangular pleurites.

Thoracic appendages.-Chelate P1; P1 propodus subrectangular, compressed dorso-ventrally; narrow, slightly inflated dactylar bulge, posteriorly delimited by a narrow groove; thin P1 fingers.

Ornamentation.-Carapace densely covered by very small depressions; intercalated plate with a row of small tubercles; gastric region with a row of tubercles parallel to intercalated plate; oblique orbital row of tubercles ended by an orbital spine; $\mathrm{P} 1$ propodus and fingers densely covered by depressions wider than those of the carapace.

Discussion. - This species has a complex nomenclatorial history previously exposed and explained in details by Schweigert et al. (2013). Originally, the name Glyphea amalthei was informally used by Quenstedt. It should has been published in the sixth issue of the "Jahreshefte des Vereins für vaterländische Naturkunde in Württemberg" in 1850, but the publication of this issue was delayed in 1854 . So, the first formal description of this taxon appeared in Oppel's thesis, published in 1853, with Quenstedt's authorship. However, the two specimens figured by Oppel (a chela now assigned to Schobertella simonsenetlangi Schweigert, Fraaije, Havlik and Nützel, 2013 and a carapace of Pseudoglyphea amalthea Oppel, 1861) were not Quenstedt's specimens. Förster (1966) have designated as lectotype of Eryma amalthei a fragment of P1 chela figured by Quenstedt (1858: pl. 24, fig. 57; Fig. 3AB). This fragment shows a subrectangular propodus, compressed dorso- ventrally, with a narrow dactylar bulge and thin fingers. These characteristics support the assignation of the species to Eryma. Contrary to the indications in the legend, Förster (1966: pl. 13, fig. 5) does not figured the lectotype previously figured by Quenstedt (1858: pl. 24, fig. 57), but another specimen (Quenstedt, 1858: pl. 24, fig. 58; Fig. 3C-D). According to Schweigert et al. (2013), the later specimen is quite different from the lectotype of E. amalthei in shape (less wide and more elongated, slightly inflated medially) and ornamentation (smaller depressions which are more widely spaced). We concur with Schweigert et al. (2013) and recognised the thalassinoid anomuran affinities of this fragment of $\mathrm{P} 1$ chela.
Eryma laedonensis Étallon, 1861 from the mid-Early Jurassic of Lons-le-Saunier (France) is based on a lost specimen which has its carapace preserved in connection with a P1 (Förster, 1966). Étallon noticed the proximity between the P1 chela of E. laedonensis and that of Erymaamalthei (subrectangular propodus, ornamentation made of depressions), and Förster (1966) decided to consider E. laedonensis as a junior synonym of E. amalthei. Eryma propinqua Oppel, 1862, based on a carapace from the middle of the Early Jurassic from Metz (France; Fig. 3E), has a carapace and an ornamentation identical to those of E. laedonensis. The careful examination of the original figure of Étallon (1861: pl. 8, fig. 6) reveal the strong similarities between the two species: the convergence of the postcervical and branchiocardiac grooves, their strong curvature, the absence of ventral extension for the postcervical groove, and the carapace ornamentation made of very small punctuations. These characteristics support the integration of E. laedonensis and E. propinqua into the synonymy of $E$. amalthei.

The strong sinuosity of the cervical groove and the ornamentation of the $\mathrm{P} 1$ propodus made of well-marked depressions are characteristics of Eryma amalthei, and such combination is not found in other species of Eryma. Furthermore, the strong convergence of postcervical and branchiocardiac grooves of E. amalthei is distinct from E. birdi, E. compressum, E. ornatum, E. ventrosum. Contrary to E. birdi, E. mandelslohi and E. ventrosum, the postcervical groove of E. amalthei lacks of ventral extension. Moreover, the strong curvature of the postcervical and branchiocardiac grooves distinguishes E. amalthei from E.birdi, E.compressum, E. mandelslohi, E. ornatum, E. sinemurianum and E. ventrosum.

\subsection{Eryma birdi Woods, 1930}

Fig. 4

Astacus birdii Bean, 1839: 58 (nomen nudum).-Schweitzer et al., 2010: 23.

Eryma birdi Woods, 1930: 74, pl. 20, figs 1-2, pl. 21, fig.1. Glyphea birdii-Wright, 1860: 4 (nomen nudum).Glaessner, 1929: 184 (nomen nudum).

Eryma birdii-Phillips, 1875: 241 (nomen nudum). - FoxStrangeways, 1892: 147 (nomen nudum).

Type material. - Holotype NHMUK In.27125; two paratypes NHMUK In.27123, In.27124.

Type locality.-Peak, Yorkshire, United- Kingdom.

Type age. - Toarcian, Early Jurassic.

Description.

Carapace.-Sub-cylindrical carapace; short, spineless rostrum; dorsal margin of cephalic region curved downward; fusiform intercalated plate; narrow post-orbital area; elongated cardiac region; deep, wide cervical groove, joined to dorsal margin and to antennal groove; deep, narrow antennal groove; short, deep gastro-orbital groove, originating as a slight median inflexion of cervical groove; deep postcervical groove, almost straight, strongly inclined, not joined to dorsal margin and joined to branchiocardiac groove at carapace mid-height, with a short ventral extension; deep branchiocardiac groove, subparallel to postcervical groove, almost straight dorsally, slightly curved towards its junction with hepatic groove, strongly inclined, not joined to dorsal margin and to hepatic groove; deep, wide hepatic groove, concavo-convex, joined to cervical groove; inflated $\omega$ and $\chi$ areas, strongly rounded in shape; deep, wide inferior groove. 


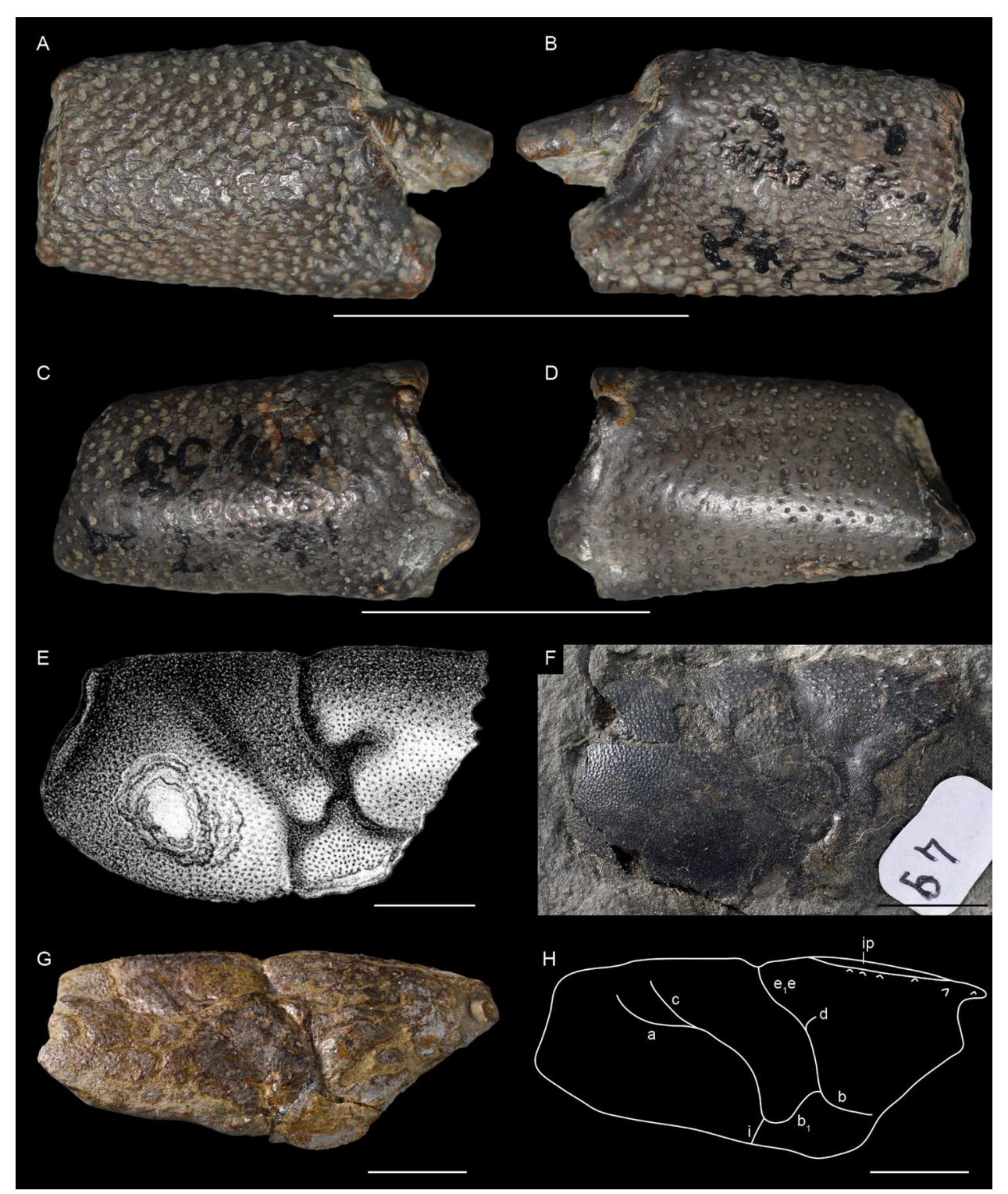

Fig. 3. Eryma amalthei (Quenstedt, 1850) and thalassinoid specimen from the Pliensbachian. A-D: lectotype GPIT/43/24/57 from Holzmaden (Germany): dorsal view (A), ventral view (B); C-D: specimen of thalassinoid affinities GPIT/43/24/58 originally assigned to Glyphea amalthea from Holzmaden (Germany): dorsal view (C), ventral view (D); E: original figure of Oppel (1862: pl. 4; fig. 6) of the holotype of Eryma propinqua Oppel, 1862; F: specimen MAN without number from Nancy (France); G-H: specimen FSL 170753 from Auxon (France): lateral view $(\mathrm{J})$, line drawing $(\mathrm{K})$. Scale bars: $1 \mathrm{~cm}$. Abbreviations: a: branchiocardiac groove; $b$ : antennal groove; $b_{1}$ : hepatic groove; c: postcervical groove; d: gastro-orbital groove; $\mathrm{e}_{1}$ e: cervical groove; i: inferior groove; ip: intercalated plate. Photographs: J. Devillez (A-D), P. Loubry (F-G). Line drawing: J. Devillez.

Pleon and uropods.-Somites with subtriangular pleurites, with a longitudinal bulge on their basis; $s 2$ pleurites wider than that of other somites.

Thoracic appendages.-Chelate $\mathrm{P} 1$; P1 propodus subrectangular, wide, compressed dorso-ventrally; narrow, slightly inflated dactylar bulge, posteriorly delimited by a wide groove; elongated, thin P1 fingers, curved inward; occlusal margin with thin, sharp conical teeth, widely spaced; P1 carpus short, subtriangular; elongated P1 merus, triangular in section.

Ornamentation. - Carapace ornamentation heterogeneous; cephalic, cardiac, hepatic and pterygostomial regions covered by tubercles preceded by shallow depressions; oblique orbital row of tubercles in gastric region; branchial region densely covered by deep rounded depression; pleonal tergites and pleurites covered by small, widely spaced tubercles; P1 propodus and fingers densely covered by small tubercles.

Discussion. - Bean (1839) has firstly attributed the specific epithet "birdii" to a new crustacean species assigned to the genus Astacus J.C. Fabricius, 1775. However, the absence of description, illustration and reference to a collection or to a specimen in a collection made of Astacus birdii a nomen nudum. This nomen nudum has been mentioned or figured, but 


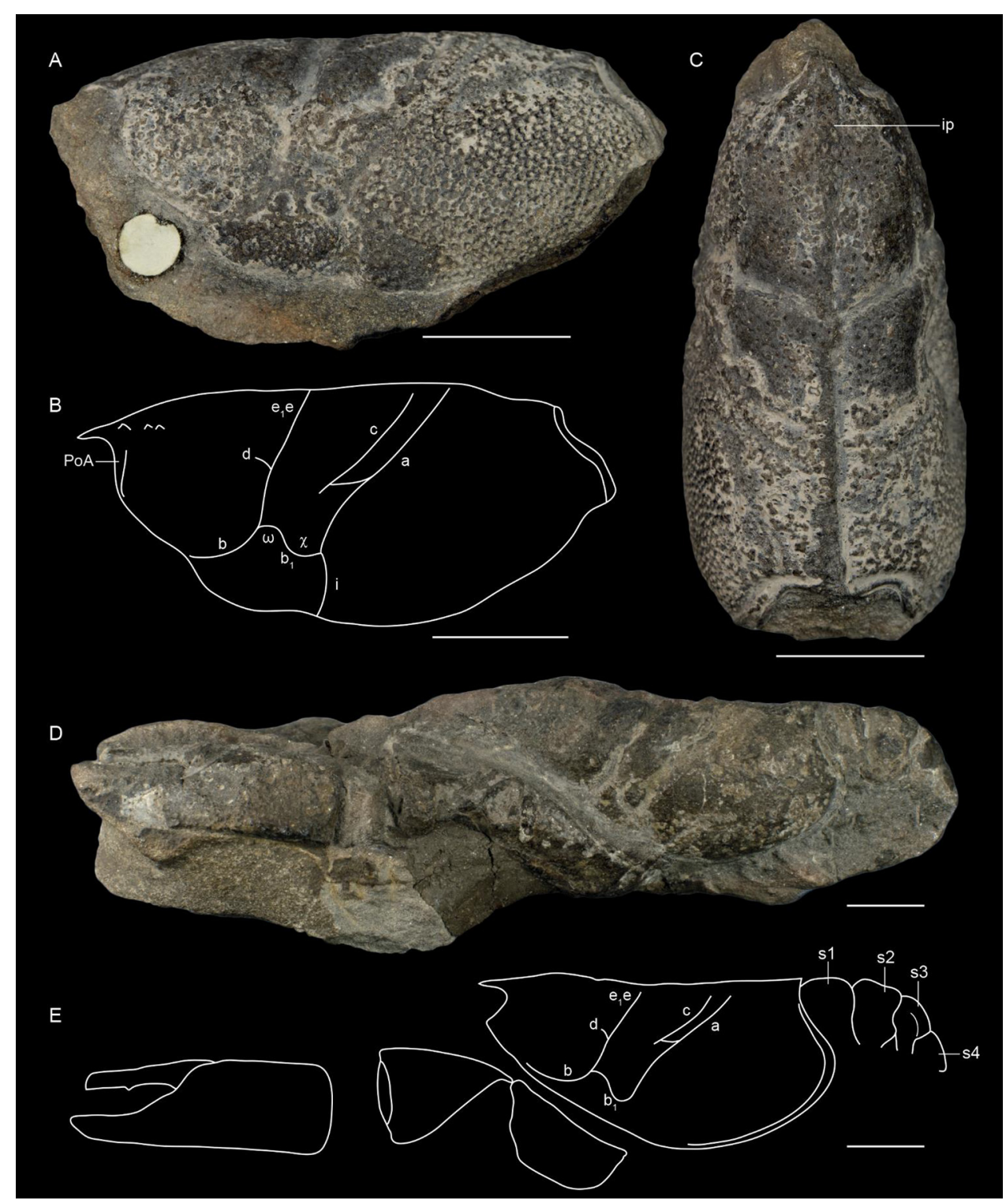

Fig. 4. Eryma birdi Woods, 1930 from the Toarcian of Peak (United Kingdom). A-C: holotype NHMUK In.27125: lateral view (A), schema (B), dorsal view (C); D-E: paratype NHMUK In.27123: lateral view (D), schema (E). Scale bars: $1 \mathrm{~cm}$. Abbreviations: a: branchiocardiac groove; b: antennal groove; b1: hepatic groove; c: postcervical groove; d: gastro-orbital groove; $\mathrm{e}_{1} \mathrm{e}$ : cervical groove; i: inferior groove; ip: intercalated plate; PoA: postorbital area; s1-4: pleonal somites; $\chi$ : attachment site of adductor testis muscle; $\omega$ : attachement site of mandibular muscle. Photographs: J. Devillez. Line drawings: J. Devillez.

not solved, by Wright (1860), Phillips (1875), Fox-Strangeways (1892) and Glaessner (1929). Woods (1930) was the first author to give a real description of Bean's A. birdii. Woods kept almost the same specific epithet, which became valid, and assigned the species to Eryma. The short gastro-orbital groove, the junction between the postcervical and branchiocardiac grooves at carapace mid-heigth, and the sinuous hepatic groove support this generic assignation.

Eryma birdi is distinct from other Eryma species, excepted Eryma sulcatum Harbort, 1905, by the ornamentation of its branchial region made of wide depressions. The downward curvature of the dorsal part of the cephalic region of E. birdi is also unique among other Eryma species from the Early and
Middle Jurassic. The fact that both $\omega$ and $\chi$ areas are inflated distinguished E. birdi from E. amalthei, E. compressum, and E. mandelslohi.

\subsection{Eryma compressum (Eudes-Deslongchamps, 1842)}

Figs. 5-6

Palinurus compressus Eudes-Deslongchamps, 1842: 60, pl. 4, figs 8-9.

Glyphea aalensis Quenstedt, 1858: 349; 1885: 410, fig. 128. nov. syn.

Glyphea bedelta Quenstedt, 1858: 391, pl. 53, figs 5-6. nov. syn. 


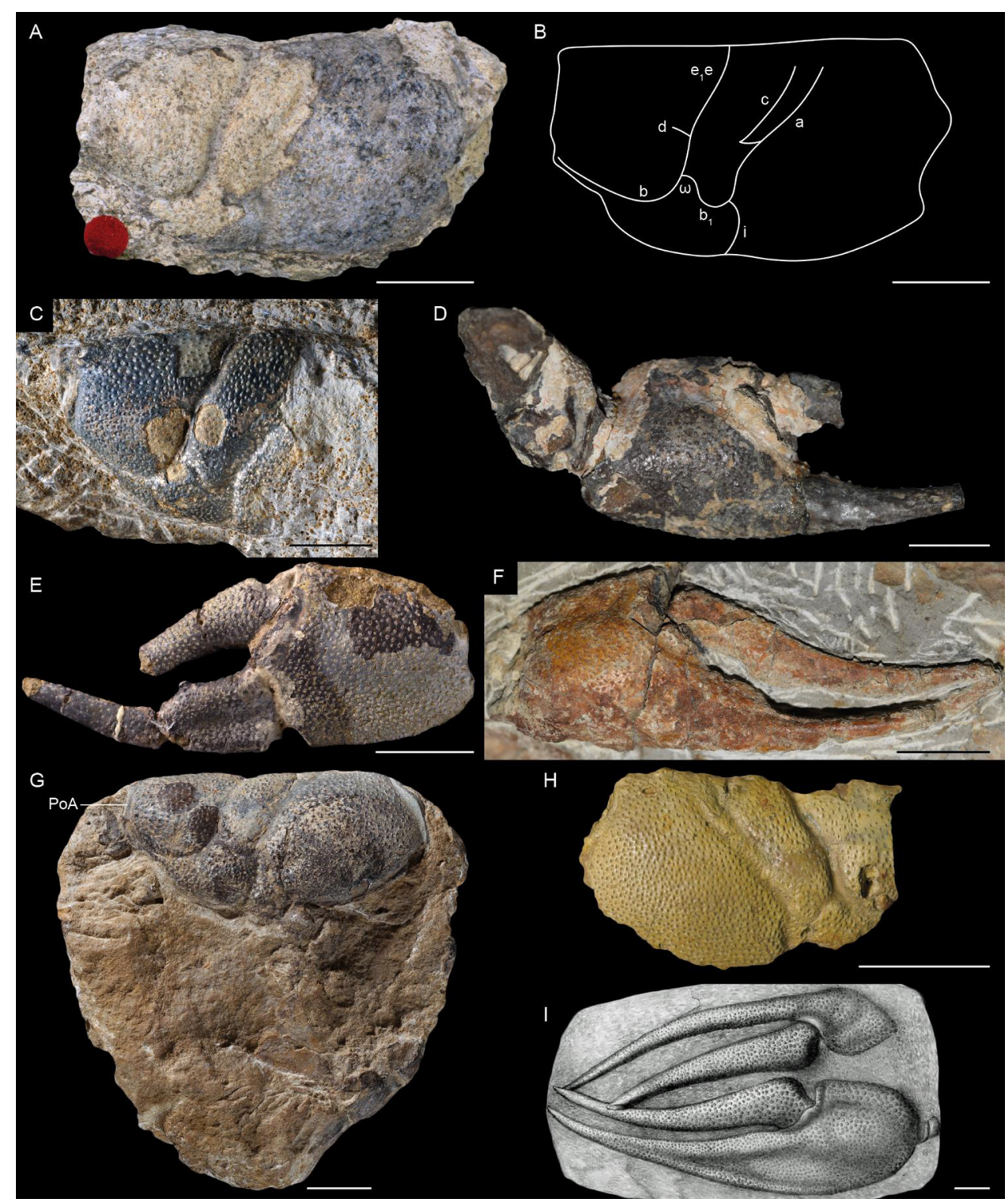

Fig. 5. Type material of Eryma compressum (Eudes-Deslongchamps, 1842) and of its synonyms. A-B: holotype NHMUK In.22917 from the Bathonian of Ranville (France): general view (A), line drawing (B); C: lectotype GPIT 43/53-5 of Glyphea bedeltum Quenstedt, 1858 from the Bajocian of Balingen (Germany); D: holotype GPIT without number of Glyphea aalensis Quenstedt, 1858 from the Aalenian of Aalen (Germany); E: holotype MNHN.F.A29729 of Bolina etalloni Ferry, 1861 from the Bajocian of Solutré (France); F: holotype GPIT without number of Erymastacus quenstedti Beurlen, 1928 from the Bajocian of Beuren (Germany); G: holotype FSL EM 80059 of Eryma elegans Oppel, 1862 from the Bajocian of Longwy (France); H: holotype MAN 2015.0.228 of Eryma authelini Méchin, 1901 from the Aalenian of Amances (France); I: original figure of Morière (1888: pl. 4, fig. 2) of Eryma bizeti Morière, 1888 from the Bathonian of Ecouché (France). Scale bars: $1 \mathrm{~cm}$. Abbreviations: a branchiocardiac groove; $b$ : antennal groove; $b_{1}$ : hepatic groove; $c$ : postcervical groove; $e_{1} e$ : cervical groove; i: inferior groove; PoA: postorbital area; $\omega$ : attachement site of mandibular muscle. Photographs: J. Devillez (A, D, F, H), P. Havlik (C), P. loubry (E), N. Robin (G). Line drawing: J. Devillez.

Eryma wuerttembergica Oppel, 1861: 357; 1862: 25. - Van Straelen, 1925: 240.-Beurlen, 1928: 160, 168. nov. syn.

Eryma aspera Oppel, 1861: 357; 1862: 26.-Beurlen, 1928: 160. nov. syn.

Eryma elegans Oppel, 1861: 357; 1862: 264, pl. 4, fig. 7.-Trautschold, 1866: 20.-Woodward, 1877: 10.-Wright, 1881: 58, 59. - Carter, 1886: 549. - Krause, 1891: 200. - Harbort, 1905: 17. - Van Straelen, 1925: 243, fig. 113, pl. 7, fig. 3.-Beurlen, 1928: 159, 160.-Woods, 1930: 76. nov. syn.
Bolina etalloni Ferry, 1861: 31-32; 1865: 368, pl. 7, figs 12. - Van Straelen, 1925: 242. - Glaessner, 1929: 153. nov. syn. Eryma bizeti Morière, 1888: 140, pl. 4, fig. 2.-Hée, 1924: 130.-Secrétan, 1964: 69.-Förster and Seyed-Emami, 1982: 43. nov. syn.

Eryma elegans gracilis Krause, 1891: 198, pl. 13, fig. 3. - Van Straelen, 1925: 245.-Beurlen, 1928: 160. nov. syn. Eryma ventrosa subhercynica Krause, 1891: 198.-Beurlen, 1928: 160. nov. syn. 

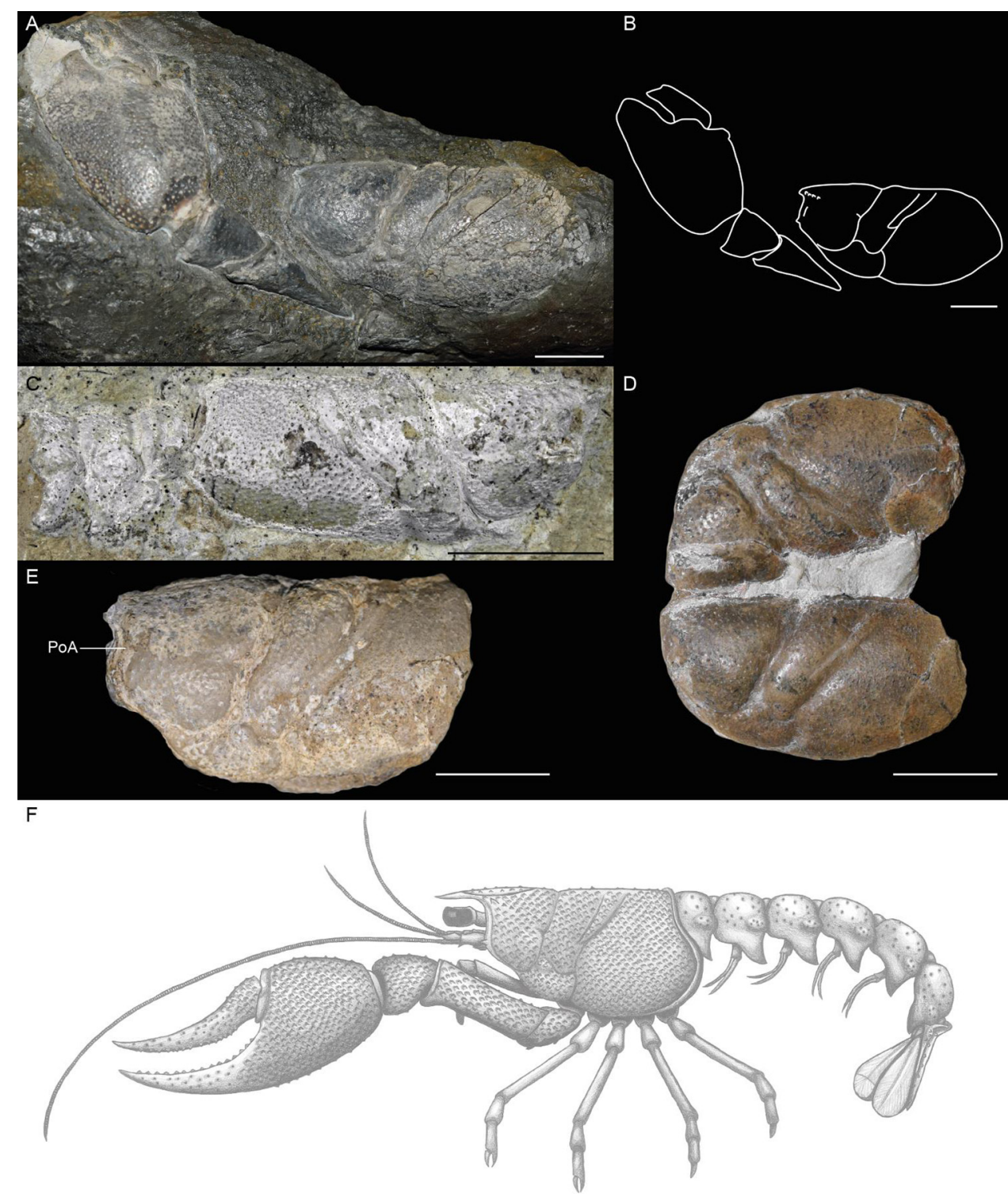

Fig. 6. Additionnal specimens of Eryma compressum (Eudes-Deslongchamps, 1842) and reconstruction. A-B: specimen specimen SMNS 70195 from the Bajocian of Öschingen (Germany): general view (A), line drawing (B); C: specimen NHMUK In.27131 from the Bathonian of Kingsthorpe (United Kingdom); specimen BSPG 1964 I 340 from the Aalenian of Geislingen (Germany); specimen GPIT without number from the Bajocian of Öschingen (Germany); F: reconstruction. Scale bars: $1 \mathrm{~cm}$. Abbreviation: PoA: postorbital area. Photographs, line drawing and drawing: J. Devillez.

Eryma elegans major Lahusen, 1894: 318. - Van Straelen, 1925: 244. - Beurlen, 1928: 160. nov. syn.

Eryma gaiffei Méchin, 1901: 80, fig. 2.-Van Straelen, 1925: 239. - Glaessner, 1929: 154. nov. syn.

Eryma authelini Méchin, 1901: 80, fig. 7.-Van Straelen, 1925: 241.-Glaessner, 1929: 151. nov. syn.

Eryma nicklesi Méchin, 1901: 81, fig. 5-6. - Van Straelen, 1925: 239. - Glaessner, 1929: 157. - Förster, 1966: 95. -Feldmann and Titus, 2006: 64. - Schweitzer et al., 2010: 24. nov. syn.

Eryma oppeli Beurlen, 1928: 158, 162, 163.-Glaessner, 1929: 157. nov. syn.

Erymastacus quenstedti Beurlen, 1928: 173. - Hyžný et al., 2015: 375, 376. nov. syn.
Eryma aalensis-Oppel, 1861: 356; 1862: 25.-Hée, 1924: 131. - Van Straelen, 1925: 238. - Glaessner, 1929: 151. - Devillez et al., 2016: 524.

Eryma compressa-Oppel, 1861: 357; 1862: 27.-Hée, 1924: 132. - Van Straelen, 1925: 251.-Glaessner, 1929: 152. - Förster, 1966: 102. - Feldmann and Titus, 2006: 63.

Astacus bedelta-Quenstedt, 1867: 320; 1885: 410, pl. 32, fig. 12 .

Eryma sp.-Morière, 1888: 140, pl. 4, fig. 1.

Glyphea (Eryma) aalensis-Krause, 1891: 198, pl. 13, fig. 2.

Eryma bedelta - Van Straelen, 1925: 241, fig. 112.-Beurlen, 1928: 157, 158, 159, 161, 162, 163, 168, pl. 7, figs 1920. - Glaessner, 1929: 151. - Woods, 1930: 74 (non pl. 20, figs 
3-7). - Beurlen, 1933: 91. - Vialle, 1948: 60. - Secrétan, 1964: 69. - Förster, 1966: 95, fig. 14, pl. 13, figs 7-12, pl. 14, figs 26.-Feldmann, 1979: 4.-Taylor, 1979: 24, 34.-Förster and Seyed-Emami, 1982: 43. - Secrétan, 1984: 515, fig. 1.-Crônier and Courville, 2004: 1006, 1007.-Etter, 2004: 384. - Schweitzer et al., 2009: 3, figs 1.1-1.2.

Erymastacus aalensis-Beurlen, 1928: 173, pl. 6, fig. 3.-Hyžný et al., 2015: 375, 376, 379.

Clytia bizeti-Glaessner, 1929: 115.

Eryma bedelta gracilis-Glaessner, 1929: 151.-Secrétan, 1964: 68 .

Eryma bedelta major-Glaessner, 1929: 152.

Eryma bedelta rugosa-Glaessner, 1929: 152.

Eryma quenstedti-Glaessner, 1929: 162.-Devillez et al., 2016: 524.

Eryma cf. bedelta-Förster, 1966: 100, pl. 14, fig. 3.

Eryma guisei-Förster, 1966: 100, pl. 14, fig. 4 (non 5).

Eryma bedeltum - Schweitzer et al., 2010: 23. - Karasawa et al., 2013: tab. 1. - Bravi et al., 2014: 94.-Charbonnier et al., 2014: 336, fig. 5. - Hyžný et al., 2015: 379.

Eryma compressum-Schweitzer et al., 2010: 23.-Bravi et al., 2014: 94.

Glyphea regleyana (pars.) - Whicher et al., 2016: fig. 6.

Type material. - Holotype NHMUK 22917.

Type locality.-Ranville, Calvados department, Basse Normandie, France.

Type age.-Bathonian, Middle Jurassic.

Description.

Carapace.-Sub-cylindrical carapace; slightly elongated, spineless rostrum; fusiform intercalated plate; smooth, slightly inflated post-orbital area; gastric region slightly inflated; deep, wide cervical groove, slightly curved dorsally, almost straight and subvertical under its median inflexion, joined to dorsal margin and to antennal groove; deep, narrow antennal groove; short, shallow gastro-orbital groove, originating as a median inflexion of cervical groove; postcervical and branchiocardiac grooves subparallel, closely spaced, not joined to dorsal margin; deep, narrow postcervical groove, curved, joined to branchiocardiac groove at carapace mid- height; deep, wide branchiocardiac groove, curved with a slight inflexion towards its junction with hepatic groove; deep, shallow hepatic groove, concavo-convex, joined to cervical groove; inflated $\omega$ area; flat $\chi$ area; deep, wide inferior groove, joined to hepatic groove.

Pleon and uropods. - Somites with subrectangular tergites; somites with narrow subtriangular pleurites, directed backward, with an elliptic longitudinal bulge on their basis; s2 pleurites wider than that of other somites; s6 pleurites shorter; rounded telson, with two longitudinal crests, wider in their proximal part.

Thoracic appendages.-Chelate $\mathrm{P} 1$; P1 propodus trapezoidal, wide, compressed dorso-ventrally, with a median longitudinal bulge on its ventral surface; narrow, inflated dactylar bulge, posteriorly delimited by a wide and deep groove; elongated, thin P1 fingers, equal in length, progressively narrowing to their distal extremity, curved inward; wide index basis; occlusal margin with short conical teeth, regularly spaced; P1 carpus short, subtriangular; elongated P1 merus, triangular in section, with a short process at outer side of its ventral extremity.

Ornamentation.-Carapace with a dense ornamentation made of small tubercles preceded by small crescent- shaped depressions; cephalic region with an oblique orbital row of tubercles ended by an orbital spine; antennal region with an antennal spine; pleonal tergites and pleurites covered by small, rounded and wide-spaced depressions; telson covered by small, wide-spaced tubercles; P1 propodus, carpus and merus densely covered by small tubercles preceded by crescent shaped depressions; P1 fingers with small tubercles on their basis and by rounded depressions on the remaining part.

Discussion. - Eudes-Deslongchamps (1842) described Palinurus compressus after a carapace bearing a short gastro-orbital groove, a junction between postcervical and branchiocardiac grooves at carapace mid-height and a concavo-convex hepatic groove. According to Oppel (1861; 1862), Hée (1924), Van Straelen(1925), Glaessner(1929), Förster(1966), Feldmann and Titus (2006), Schweitzer et al. (2010) this groove pattern justifies the assignation of the species to Eryma.

The comparison of the carapace groove pattern and ornamentation between Eryma bedeltum (Quenstedt, 1858) (Bajocian, Germany; Fig. 5C) and the holotype of $E$. compressum (Fig. 5A-B) revealed strong similarities: cervical groove curved dorsally; postcervical groove curved and without ventral extension; dense ornamentation, made of small tubercles preceded by crescent-shaped depressions. Considering these characteristics, we consider $E$. bedeltum as a junior synonym of E. compressum. Moreover, the type of Eryma aspera Oppel, 1861 (Bajocian, Germany) is in fact the type of E. bedeltum. So, E. aspera is also a synonym of E. compressum.

After his review of the erymid lobsters, Förster (1966) recognized numerous species as synonyms of E. bedeltum. Some are only known by isolated P1 chelae: Glyphea aalensis Quenstedt, 1858 (Aalenian, Germany; Fig. 5D), Bolina etalloni Ferry, 1861 (Bajocian, France; Fig. 5E) and Erymastacus quenstedti Beurlen, 1928 (Bajocian, Germany; Fig. 5F). These P1 chelae share the same characteristics: trapezoidal propodus with a longitudinal median bulge on ventral surface; narrow dactylar bulge; long fingers, progressively narrowing to their distal extremity and curved inward; index with a wide basis. These characteristics correspond to that of the P1 chelae of E. compressum. Hence, we consider $G$. aalensis, B. etalloni and E. quenstedti as a junior synonyms of E. compressum. Other forms are known by their carapaces: Eryma elegans Oppel, 1862 (Bajocian, France; Fig. 5G) and its varieties established by Krause (1891) and Lahusen (1894), and Eryma authelini Méchin, 1901 (Aalenian, France; Fig. $5 \mathrm{H})$. They exhibit a cervical groove curved dorsally, a curved postcervical groove lacking of ventral extension and joined to the branchiocardiac groove, a dense ornamentation made of small tubercles preceded by crescent-shaped depressions. These characteristics are identical to those of E. compressum, so we add E. elegans and E. authelini in the synonymy of E. compressum.

The type materials of Eryma bizeti Morière, 1888 (Bathonian, France; Fig. 5I), Eryma lafayi Lissajous, 1923 (Bathonian, France), Eryma wuerttembergica Oppel, 1861 (Bajocian, Germany), Eryma gaiffei Méchin, 1901 (Toarcian, France) and Eryma nicklesi Méchin, 1901 (Toarcian, France) are currently lost or destroyed. E. bizeti and E. lafayi are only known by their P1 chelae. The examination of their descriptions and figures reveals very close characteristics to those of the P1 chelae of $E$. 
compressum (trapezoidal propodus with a longitudinal median bulge on ventral surface; narrow dactylar bulge; long fingers, progressively narrowing to their distal extremity and curved inward; index with a wide basis; dense, fine ornamentation). E. wuerttembergica is known by a carapace found in the same outcrop than the lectotype of E. bedeltum, and figured by Quenstedt (1858: pl. 53, fig. 6). Careful examination of the figure shows that $E$. wuerttembergica has a postcervical groove joined to the branchiocardiac groove, no ventral extension for the postcervical groove and the ornamentation is dense and fine. The figures of the types of E. gaiffei and E. nicklesi show similar characteristics with the addition of a short gastro-orbital groove, a hepatic groove concavo-convex, and an inflated $\omega$ area. Considering all these characteristics, we consider E. bizeti, E. lafayi, E. wuerttembergica, E. gaiffei and E. nicklesi as a junior synonyms of E. compressum. We noticed the absence of junction between the postcervical and branchiocardiac grooves on the schemas of the carapace groove pattern draw by Méchin (1901). This is probably due to the fact that this junction is weakly marked in E. compressum. Eryma oppeli Beurlen, 1928 (Bajocian, Germany) is known by two carapaces that have not been localised nor figured. Beurlen compared the carapace groove pattern and the ornamentation of E. oppeli to E. bedeltum. The differences pointed between these two forms are minor: cervical groove slightly wider, postcervical and branchiocardiac grooves closer, ornamentation slightly less dense, depressions smaller in E. oppeli. These differences do not support a clear distinction between E. oppeli and E. bedeltum. Hence, we consider E. oppeli as a junior synonym of E. compressum, like E. bedeltum.

Eryma compressum is a typical erymid species in the Middle Jurassic of Western Europe. Some occurrences in Iran (Förster and Seyed-Emami, 1982), in Morocco (Secrétan, 1984) and in Romania (Schweitzer et al., 2009) suggest a palaeogeographic distribution clearly wider than the European boundaries. E. compressum is the only species of Eryma of the Early and Middle Jurassic to have an inflated ventral surface of the P1 propodus. Moreover, the trapezoidal shape of the P1 propodus is distinct of the subrectangular propodus of E. amalthei, E.birdi, E. osciensis, E. sinemurianum, and E. ventrosum. The curved fingers of E. compressum is also distinct of the straight fingers of E. osciensis. On the carapace groove pattern, E. birdi, E. mandelslohi and E. ventrosum have a postcervical groove with a ventral extension while it is absent in E. compressum. Finally, the ornamentation of E.compressum made of small tubercles preceded by crescent-shaped depressions is distinct of that of E. amalthei, E. mandelslohi, E. osciensis and E. sinemurianum, made exclusively of tubercles or depressions.

\subsection{Eryma mandelslohi (Meyer, 1840b)}

Fig. 7

Klytia mandelslohi Meyer, 1840b: 21, pl. 4, fig. 30.-Quenstedt, 1850: 186, 195.-Devillez and Charbonnier, 2017: 4

Eryma karitzkyi Lahusen, 1894: 314, pl. 1, fig. 1.-Van Straelen, 1925: 252.-Glaessner, 1929: 156.-Birshtein, 1956: 75.-Secrétan, 1964: 70.-Förster, 1966: 103.-Ilyin, 2000:
152.-Crônier and Courville, 2004: 1007.-Feldmann and Titus, 2006: 64.-Schweitzer et al., 2010: 24. nov. syn.

Eryma orthodactylus Beurlen, 1928: 157, 161, 162, 163, pl. 7, fig. 8, figs 12-14.-Glaessner, 1929: 158.

Eryma curva Beurlen, 1928: 162, pl. 7, figs 911.-Glaessner, 1929: 153.

Clytia mandelslohi-Bronn, 1849: 578.-Quenstedt, 1858: 520, pl. 69, fig. 7.-Étallon, 1859: 196.

Astacus mandelslohi-Quenstedt, 1852: 269; 1867: 320.

Eryma mandelslohi-Étallon, 1861: 167, pl. 8, fig. 8.-Oppel, 1861: 357; 1862: 28, pl. 5, figs 3-4.-Ferry, 1865: 370.-Carter, 1886: 546, pl. 16, fig. 2.-Lahusen, 1894: 315. - Van Straelen, 1925: 257, fig. 121, pl. 8, figs 56. - Beurlen, 1928: 156, 157, 161, 162, 163, 164, 166, pl. 7, fig. 7.-Glaessner, 1929: 156. - Woods, 1930: 77, pl. 21, fig. 8. - Secrétan, 1964: 67, 70. - Förster, 1966: 104, fig. 16, pl. 14, figs 9-10, 12.-Martill, 1991: 180, fig. 7.3b (non j). - Crônier and Courville, 2004: 1007.-Feldmann and Titus, 2006: 64. - Schweitzer et al., 2010: 24.

Astacus mandelslohi-Quenstedt, 1885: 410.

Eryma stricklandi-Förster, 1966: pl. 15 figs 2-3, 6.

Eryma curvum-Schweitzer et al., 2010: 23.

Eryma orthodactylum - Schweitzer et al., 2010: 24.

Type material. - Holotype not located, cast NMB 4881.

Type locality.-Metzingen, Baden- Württemberg,

Germany.

Type age.-Callovian, Middle Jurassic.

Description.

Carapace.-Sub-cylindrical carapace; slightly elongated, spineless rostrum; fusiform intercalated plate; orbital notch slightly curved; inflated post-orbital area; elongated cardiac region; branchial region short dorsally; deep, wide cervical groove, slightly inflected at carapace mid-height, joined to dorsal margin and to antennal groove; deep, narrow antennal groove; short, shallow gastro-orbital groove, oblique, originating as a slight median inflexion of cervical groove; deep, wide postcervical groove, slightly curved, convergent with branchiocardiac groove, joined to branchiocardiac groove, with a very short ventral extension;

deep, wide branchiocardiac groove, slightly inflected towards its junction with hepatic groove, joined to posterior extremity of hepatic groove; deep hepatic groove, concavoconvex, joined to cervical groove; inflated $\omega$ area; flat $\chi$ area; deep, wide inferior groove, joined to hepatic groove.

Pleon and uropods.-Somites with subtriangular pleurites, with a rounded bulge on their basis.

Thoracic appendages. - Chelate $\mathrm{P} 1$; P1 propodus trapezoidal, short, compressed dorso-ventrally; narrow, inflated dactylar bulge, posteriorly delimited by a narrow groove; thin P1 fingers, longer than propodus, equal in length; index slightly curved inward, with a strong bulge at its basis; almost straight dactylus; occlusal margin without teeth; P1 carpus short, subtriangular; elongated P1 merus, triangular in section, with a short process at outer side of its ventral extremity.

Ornamentation.-Carapace covered by depressions; depressions closer, deeper and wider in antennal, branchial, hepatic and pterygostomial regions; small, widely spaced depressions cardiac and gastric regions; gastric region with an oblique row of tubercles ended by an orbital spine; antennal region with tubercles between the depressions; pleonal tergites 


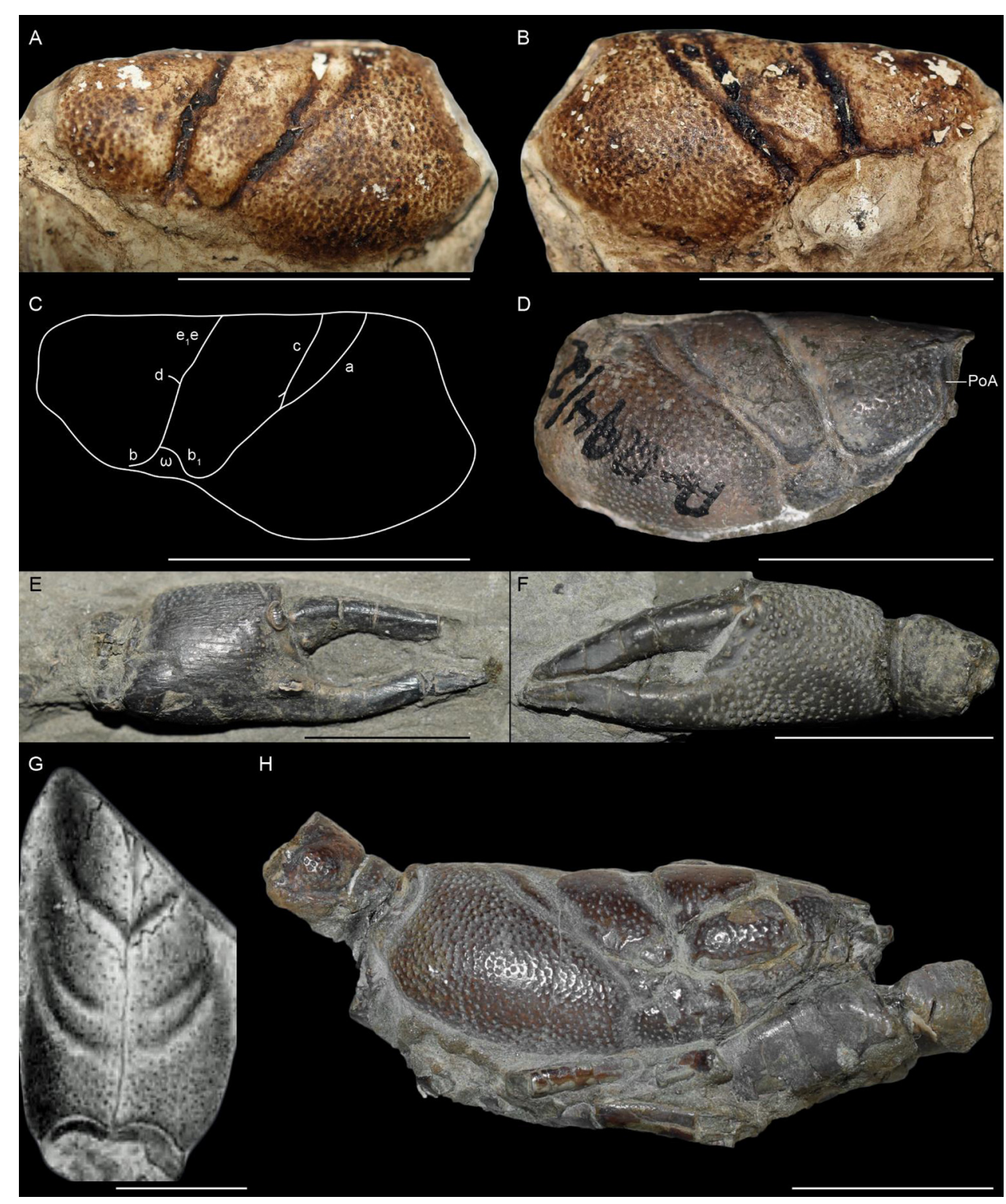

Fig. 7. Eryma mandelslohi (Meyer, 1840b) from the Callovian. A-C: cast of the holotype NMB 4881 from Metzingen (Germany): left lateral view (A), right lateral view (B), schema (C); D: specimen GPIT Ar 1294/2; E: syntype SMNS 29680 of Eryma curva Beurlen, 1928 from Reutlingen (Germany); F, syntype SMNS 29684 of Eryma orthodactylus Beurlen, 1928 from Ursulaberg hill near Reutlingen (Germany); G: original figure of Lahusen (1894: pl. 1, fig. 1) of Eryma karitzkyi Lahusen, 1894 from Kanev (Ukraine); H: specimen BSPG AS VIII 113 from Metzingen (Germany). Scale bars: $1 \mathrm{~cm}$. Abbreviations: a: branchiocardiac; b: antennal groove; $b_{1}$ : hepatic groove; c: postcervical; d: gastroorbital groove; $\mathrm{e}_{1} \mathrm{e}$ : cervical groove; PoA: postorbital area; $\omega$ : attachement site of mandibular muscle. Photographs: J. Devillez. Line drawing: J. Devillez.

covered by small, rounded and widely spaced depressions; pléonal pleurites densely covered by rounded, deep depressions; P1 propodus densely covered by small tubercles preceded by small crescent-shaped depressions; P1 carpus covered by small, rounded and widely spaced depressions; smooth P1 merus.

Discussion.-The type of Klytia mandelslohi Meyer, $1840 \mathrm{~b}$ is currently lost, but a cast is stored in the collections of the NMB (Fig. 7A-B). The carapace groove pattern on this cast is typical of Eryma: short gastro-orbital groove, postcervical and branchiocardiac grooves joined at carapace mid-height, sinuous hepatic groove.
Lahusen (1894) described Eryma karitzkyi (Callovian, Ukraine; Fig. 7G) on the basis of a carapace with slightly curved and convergent postcervical and branchiocardiac grooves, and covered by depressions. These morphological features are characteristics of Eryma mandelslohi. So, E. karitzkyi is here considered as a junior synonym of E. mandelslohi.

The syntypes of Eryma curvum Beurlen, 1928 (Fig. 7E) and Eryma orthodactylus Beurlen, 1928 (Fig. 7F) from the Callovian of Germany are P1 chelae characteristics of E. mandelslohi because of their short trapezoidal propodus bearing thin fingers, slightly longer than propodus, lacking of 
teeth, and with a bulge at the index basis. According to Förster (1966) , E.curvum and E. orthodactylus are considered as a junior synonyms of E. mandelslohi.

The bulge located at the basis of the P1 index in E. mandelslohi is a unique feature among Eryma. The carapace groove pattern of E. mandelslohi is distinct from E. amalthei, E. birdi, E. compressum, E. ornatum, and E. ventrosum because of the slight curvature of the postcervical groove. The branchial region of E. mandelslohi is also shorter dorsally than that of E.birdi, E.compressum, E. sinemurianum, and E. ventrosum. The trapezoidal $\mathrm{P} 1$ propodus of E. mandelslohi is distinct the species with a subrectangular P1 propodus: E. birdi, E. osciensis, E. sinemurianum, and E. ventrosum. At least, the carapace Ornamentation of E. mandelslohi, made of depressions, is distinct to E. birdi, E. compressum, E. ornatum, E. osciensis, and E. ventrosum.

\subsection{Eryma ornatum (Quenstedt, 1858)}

Fig. 8

Glyphea ornati Quenstedt, 1858: 519, pl. 69, figs 1-2.

Eryma calloviensis Oppel, 1861: 357; 1862: 29, pl. 5, figs 1-2.-Krause, 1891: 205.-Lahusen, 1894: 314, 345.-Van Straelen, 1925: 256, fig. 120.-Beurlen, 1928: 171, 173, pl. 6, figs 1-2; 1933: 89, 91.-Birshtein, 1956: 74.- Förster and Seyed-Emami, 1982:44. - Ilyin, 2000: 152.

Astacus ornati-Étallon, 1859: 193, 196.

Eryma ornata-Étallon, 1861: 166, pl. 8, fig. 2.-Oppel, 1861: 357; 1862: 28. - Morière, 1883: 7; 1888: 139, 140. - Van Straelen, 1925: 239. - Förster, 1966: 106, fig. 17, pl. 14, figs 8, 11.-Förster and Seyed-Emami, 1982: 44.-Crônier and Courville, 2004: 1007.-Etter, 2004: 384.-Feldmann and Titus, 2006: 64. - Feldmann and Haggart, 2008: 1794.

Astacus mandelslohi-Quenstedt, 1885: 410. 241.

Glyphea ornata - Van Straelen, 1922: 982. - Fischer, 2003:

Erymastacus ornatus - Beurlen, 1928: 173, pl. 6, figs 1-2; 1933: 90.-Hyžný et al., 2015: 375, 379.

Erymastacus cf. ornatus-Beurlen, 1928: 174; 1933: 90.

Erymastacus ornati-Glaessner, 1929: 162.-Secrétan, 1964: 74.

Eryma ornatum-Schweitzer et al., 2010: 24.-Devillez et al., 2016: 522, 524. - Devillez and Charbonnier, 2017: 6, tab. 1, fig. 2 b.

Eryma sp.-Fantescu et al., 2018: 50, fig. 3.

Type material. - Holotype GPIT/CU/00349.

Type locality.-Gammelshausen, Baden- Württemberg, Germany.

Type age. - Callovian, Middle Jurassic.

Description.

Carapace.-Sub-cylindrical carapace; deep, wide cervical groove, inclined in its dorsal part, subvertical in its ventral half, joined to dorsal margin and to antennal groove; deep antennal groove; short, deep gastro-orbital groove, originating as a median inflexion of cervical groove; deep postcervical groove, slightly curved, wide dorsally, narrowing towards its ventral extremity, not joined to dorsal margin and joined to branchiocardiac groove under the level of the gastro-orbital groove; narrow branchiocardiac groove, subparallel to postcervical groove, inflected ventrally towards its junction with hepatic groove, not joined to dorsal margin and joined to hepatic groove; deep, narrow hepatic groove, concavo-convex, joined to cervical groove; inflated $\omega$ and $\chi$ areas; deep, wide inferior groove.

Thoracic appendages.-Chelate P1; P1 propodus trapezoidal, wide, with rounded inner and outer margins, compressed dorso-ventrally; narrow, inflated dactylar bulge, posteriorly delimited by a narrow groove; elongated $\mathrm{P} 1$ fingers, equal in length, wide at their basis and progressively narrowing to their distal extremity, almost straight or curved inward; occlusal margin with short conical teeth; P1 carpus short, subtriangular; elongated P1 merus.

Ornamentation.-Carapace covered by small tubercles preceded by shallow crescent-shaped depressions; gastric region with an oblique row of tubercles ended by an orbital spine; antennal spine present; $\mathrm{P} 1$ propodus densely covered by small tubercles preceded by crescent- shaped depressions.

Discussion.-Glyphea ornati Quenstedt, 1858 was originally described from a pair of P1 chelae. Glyphea does not have true chelae at the extremities of the $\mathrm{P} 1$, so the species does not belongs to this genus. So, Étallon (1859) assigned it to Astacus J.C. Fabricius, 1775 and later moved it into Eryma (Étallon, 1861). Later, Glaessner (1929) designated Eryma ornatum as type-species of Erymastacus Beurlen, 1928. Careful examination of the type of this species has led Devillez et al. (2016) to confirm the assignation of the species to Eryma because of the trapezoidal P1 propodus, its dorso-ventral compression, the elongated fingers, curved inward and progressively narrowing to their distal extremity. It also resulted in the fall of Erymastacus into the synonymy of Eryma.

Förster (1966) considered Eryma calloviensis Oppel, 1861 (Callovian, Germany; Fig. 8B-C) as a junior synonym of E. ornatum. E. calloviensis was described from a carapace and a pair of P1 chelae strongly similar to those of E. ornatum: trapezoidal propodus, dorso-ventrally compressed, elongated fingers, curved inward, dense ornamentation made of tubercles preceded by crescent-shaped depressions. These characteristics support the synonymy between E.calloviensis and E. ornatum.

E. ornatum was only known in Germany, but a P1 chelae similar to that of E. ornatum was figured by Fantescu et al. (2018: fig. 3). This chela could be considered as a specimen of the species, extending its distribution to Romania.

The junction between the postcervical and the branchiocardiac grooves of Eryma ornatum is very low on the carapace, contrary to E. amalthei, E. birdi, E.compressum, E. mandelslohi, E. sinemurianum, and E. ventrosum: their junction are at the level of the gastro-orbital groove. Moreover, E. ornatum does not have any ventral extension of the postcervical groove, while E.birdi, E. mandelslohi, and E. ventrosum have one. E. ornatum has also both $\omega$ and $\chi$ areas inflated: it is not the case of E.amalthei, E.compressum, E. mandelslohi, and E. ventrosum. The trapezoidal $\mathrm{P} 1$ propodus of E. ornatum is distinct of the subrectangular one of E. amalthei, E. birdi, E. osciensis, E. sinemurianum, and E. ventrosum. Finally, the ornamentation made of small tubercles preceded by crescentshaped depressions allows the distinction of E. ornatum from E. amalthei, E. mandelslohi, E. osciensis and E. sinemurianum and the carapace ornamentation of E. ornatum do not have the scale aspect of that of E. birdi. 


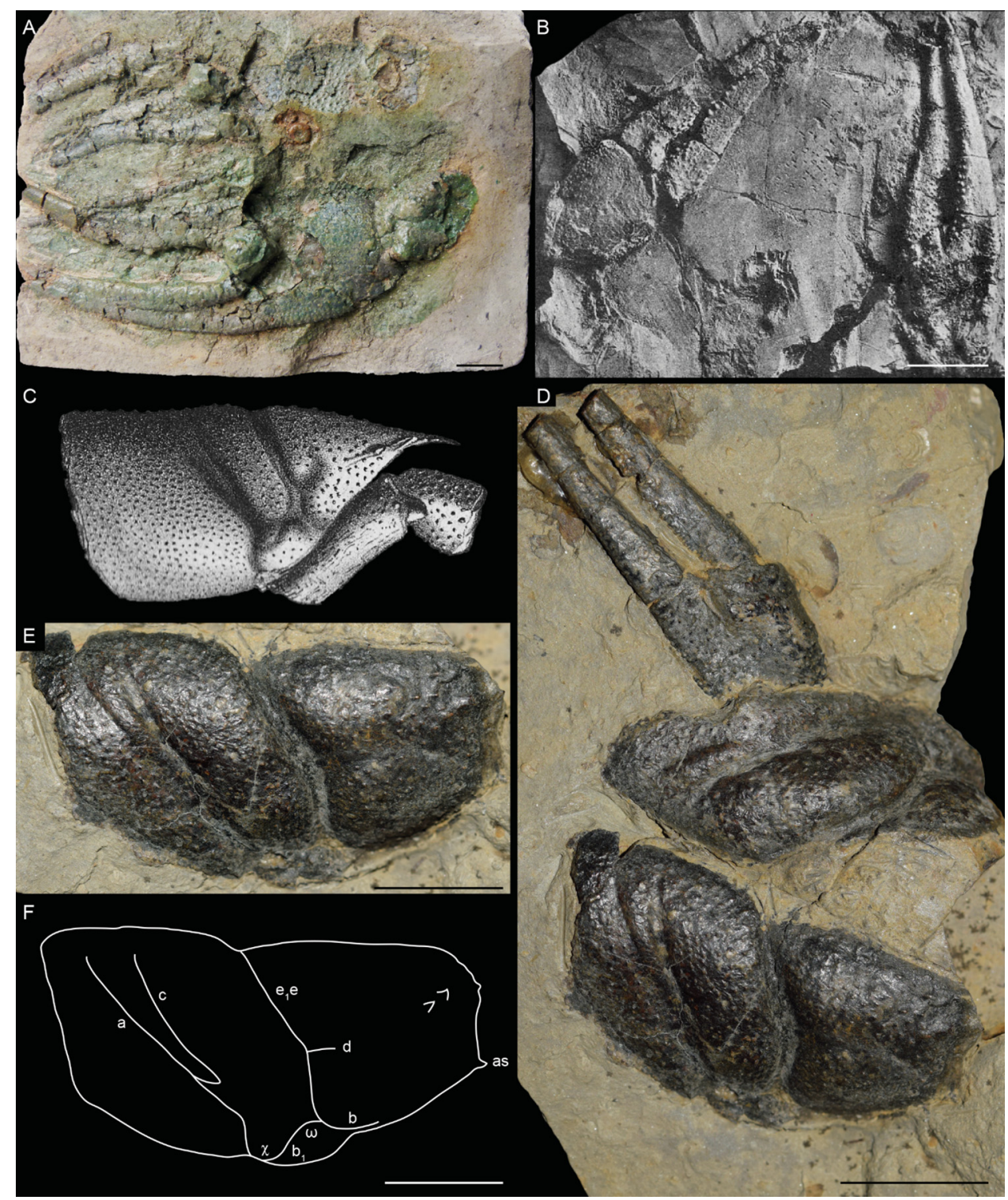

Fig. 8. Eryma ornatum (Quenstedt, 1858) from the Callovian of Germany. A: lectotype GPIT/CU/00349 from Gammelshausen; B: original figure of Beurlen (1928: pl. 6, fig. 1) of one of the syntypes of Eryma calloviensis Oppel, 1861 from Ursulaberg hill near Reutlingen; C: original figure of Oppel (1862: pl. 5, fig. 2) of one of the syntypes of E. calloviensis from Oeschingen; D-F: specimen SMNS 70284/2 from AlbstadtLautlingen: general view (D), details of the carapace (E), schema of the carapace (F). Scale bars: $1 \mathrm{~cm}$. Abbreviations: a: branchiocardiac groove; as: antennal spine; $b$ : antennal groove; $b_{1}$ : hepatic groove; $c$ : postcervical groove; $d$ : gastro- orbital groove; $e_{1} e$ : cervical groove; $\chi$ : attachment site of adductor testis muscle; $\omega$ : attachement site of mandibular muscle. Photographs: G. Schweigert (A), J. Devillez (D-F). Line drawing: J. Devillez.

\subsection{Eryma osciensis Garassino, Audo, Charbonnier and Schweigert, 2014}

Fig. 9A-D

Eryma osciensis Garassino, Audo, Charbonnier and Schweigert, 2014: 92, figs 11-12.

Type material.-Holotype CSMNF 22003v; 6 paratypes CSMNF 22003b, 220031, 22003m, 22003q, 22003s, $22003 \mathrm{a} 4$.

Type locality. - Monte Fallano, Campania, Italy.

Type age. - Bajocian-Bathonian, Middle Jurassic.

Description.

Carapace.-Sub-cylindrical carapace; short, spineless rostrum; deep cervical groove, almost straight, joined to dorsal margin and to antennal groove; short gastro-orbital groove, oblique, originating as a slight median inflexion of cervical groove; narrow, shallow postcervical and branchiocardiac grooves.

Pleon and uropods.-Somites with wide subtriangular pleurites; rounded telson; uropods as long as telson; uropodal exopods with a diaeresis.

Cephalic appendages. - Strong antennular peduncles, with three segments, last segment (basipodite) articulated with two flagella, flagella made of numerous and short cylindrical articles; strong antennal peduncles, with three segments, last segment (basipodite) articulated with a flagellum made of numerous and short cylindrical articles; wide, triangular scaphocerite. 
Thoracic appendages. - Elongated Mxp3, made of cylindrical articles; chelate P1; P1 propodus subrectangular, narrow; thin P1 fingers, almost straight, equal in length; P1 carpus short, subtriangular; elongated P1 merus; P2-P3 chelate; P2-P5 thin.

Ornamentation.-Carapace covered by small tubercles; pleonal somites smooth; $\mathrm{P} 1$ propodus and fingers covered by small tubercles; inner margin of $\mathrm{P} 1$ propodus with a row of small spines; P1 carpus covered by small tubercles, with small spines on dorsal surface.

Discussion. -Eryma osciensis Garassino, Audo, Charbonnier and Schweigert, 2014 is known by a few number of specimens preserved in compression. This preservation makes difficult the observation of the carapace grooves. However, the deep cervical groove, the short gastro-orbital groove, the presence of the postcervical and branchiocardiac grooves, and the morphology of P1 chelae support the assignation to the genus Eryma.

The preservation in compression of E. osciensis limits the comparisons with the other species of the genus. But the straight P1 fingers distinct E. osciensis from E. birdi, E. compressum, E.mandelslohi, E. ornatum, E. sinemurianum and E. ventrosum. The ornamentation of E. osciensis is only made of tubercles while that of E.amalthei, E. birdi, E. compressum, E. mandelslohi, E. ornatum, E. sinemurianum, and $E$. ventrosum includes depressions.

\subsection{Fragments attributed to Eryma}

Fig. 9E-G

Förster (1966: 94, pl. 13, fig. 3) reported as Eryma cf. amalthei some carapaces from the Sinemurian and the Pliensbachian of Germany. The specimen figured by Förster is here identified as E. amalthei, but the specimen from the Sinemurian of Ofterdingen is too badly preserved to be assigned to any species (Fig. 9E). However, it exhibits the characteristic junction between the postcervical and branchiocardiac grooves, so there is no doubt about its assignation to Eryma. Förster (1966: 94) has also designated as Eryma sp. a P1 chela from the Pliensbachian of Normandy (France), previously described and figured by Eudes-Deslongchamps (1842: 45, pl. 1, fig. 11), and identified as "une pince de pagure" (a paguroid chela). Van Straelen (1925) and Glaessner (1929) have then established Palaeastacus deslongchampsi Van Straelen, 1925 on the basis of this chela. But, its morphology does not correspond to that of the erymid lobsters because of the thin fingers curved to each other and the absence of dactylar bulge.

Quenstedt (1854: pl. 2 fig. 20) and, more recently, Schweigert et al. (2013: Fig. 8E-F) figured an isolated and incomplete P1 chela from the Late Pliensbachian of Ohmenhausen near Reutlingen (Germany), stored in the collections of the GPIT (GPIT/CU/344). The subrectangular and elongated propodus and the narrow and inflated dactylar bulge support the identification of the specimen as Eryma sp.

A crushed specimen from the Toarcian of Holzmaden, designated by Hauff (1953: 48, pl. 62, fig. c; Fig. 9F) as "Macrure", was regarded as Eryma sp. by Förster (1966: 94). The preservation of the specimen makes difficult the observation of usefull characteristics for generic identification. However, the presence of a deep cervical groove, a short gastro-orbital groove and a subrectangular P1 propodus bearing thin fingers support the assignation to Eryma. A P1 propodus typical of the genus (elongated, subrectangular, with slightly curved margins, thin fingers), from the Bathonian of Longues (France) was also righteously assigned to Eryma by Förster (1966: 100, pl. 14, fig. 3).

Two P1 chelae found in the Early Jurassic of Lyme Regis (United Kingdom) were assigned to Eryma sp. by Woods (1930: 74, pl. 19, figs 6-7). These chelae exhibit a short propodus with fingers curved outward. These characteristics do not correspond to Eryma nor to any erymid lobster.

Etter (2004: 384, Fig. 2A) righteously assigned to Eryma sp. an isolated P1 chela from the Aalenian of Schinznach (Switzerland). The propodus is subrectangular, elongated, dorso-ventrally compressed, and with thin, elongated fingers typical of the genus.

Another fragment of P1 chela found in the Bajocian of Pasul Strungulita (Romania) was identified as Eryma guisei Wright, 1881 by Schweitzer et al. (2009: 3, fig. 3). E. guisei is here assigned to Stenodactylina, so this chela should be identified as Eryma sp. beacause of its thin and elongated fingers without deviation of the outer margin at the basis of the index. Moreover, the absence of any notable feature does not allow an identification to the species level.

Krause (1891) assigned to Eryma sp. three P1 chelae from the Callovian of Hildesheim (Germany). The description clearly established the proximity between these specimens and the P1 chelae of Eryma greppini (Oppel, 1861), characteristics of the genus.

Finally, an isolated P1 chela from the Bajocian of Collonges-au-Mont-d'Or (France) stored in the collections of the FSL exhibits a propodus compressed dorso- ventrally, elongated fingers, curved inward (Fig. 9G). This is a typical P1 chela of Eryma, so this fossil is here identified as Eryma sp.

\subsection{Genus Palaeastacus Bell, 1850}

(Fig. 10A-B)

Palaeastacus Bell, 1850: 344.-Zittel, 1885: 695.-Beurlen, 1928: 180.-Förster, 1966: 126.-Glaessner, 1969: 626. - Aguirre-Urreta and Ramos, 1981: 606.-AguirreUrreta, 1989: 509.-Schweitzer and Feldmann, 2001: 174.-Feldmann et al., 2015: 3.-Hyžný et al., 2015: 375.-Devillez et al., 2016: 525, fig. 1G-H.-Devillez et al., 2017: 782.

Enoploclytia Palaeastacus-Mertin, 1941: 161.-Glaessner, 1969: 455.

Type Species.-Astacus sussexiensis Mantell, 1824 by subsequent designation of Glaessner (1929).

Emended diagnosis.-Fusiform intercalated plate; deep cervical groove, joined to dorsal margin and to antennal groove; short gastro-orbital groove, originating as a slight median inflexion of the cervical groove; postcervical and branchiocardiac grooves subparallel, joined to hepatic groove; hepatic groove concavo-convex, joined to cervical groove; inferior groove convex posteriorly, joined to hepatic groove; chelate $\mathrm{P} 1$; P1 propodus short, thick, slightly globose, with a narrow dactylar bulge; P1 fingers usually wide, slightly longer than propodus, progressively narrowing to their distal extremity, occlusal margin curved at the basis of the index. 


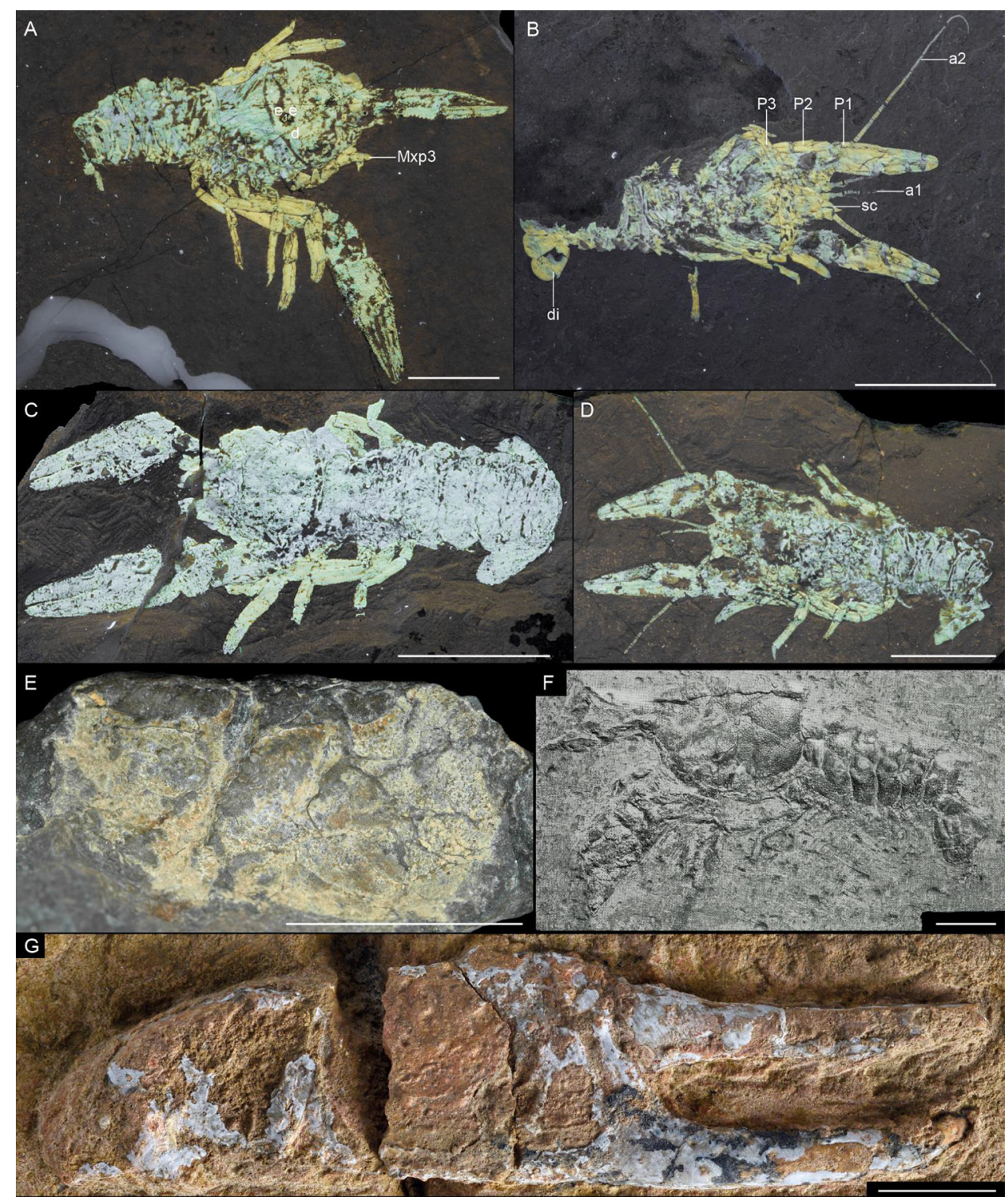

Fig. 9. Eryma osciensis Garassino, Audo, Charbonnier and Schweigert, 2014 from the Bajocian Bathonian of Monte Fallano (Italy) with UV light, and fragments of Eryma sp. A: holotype CSMNF 22003v; B: paratype CSMNF 22003q; C: specimen CSMNF 220035; D: paratype CSMNF 22003b; E: specimen GPIT without number of Eryma sp. from the Sinemurian of Ofterdingen (Germany); F: original figure of Eryma sp.from Hauff (1953: pl. 62, fig. c); G: specimen FSL 170784 of Eryma sp. from the Bajocian of Collonges-au-Mont-d'Or (France). Scale bars: $1 \mathrm{~cm}$. Abbreviations: a1: antennulae; a2: antenna; d: gastro-orbital groove; di: diaeresis; $\mathrm{e}_{1} \mathrm{e}$ : cervical groove; Mxp3: third maxilliped; P1-3: pereiopods; sc: scaphocerite. Photographs: D. Audo (A-D), J. Devillez (E), L. Cazes (G).

\subsection{Palaeastacus meyeri (Garassino, 1996)}

Fig. 10C-E

Eryma meyeri Garassino, 1996: 335, figs 1-3, figs 1517.-Schweigert and Röper, 2001: 2. - Garassino and Schweigert, 2006: 8.-Feldmann and Titus, 2006: 64.-Schweitzer et al., 2010: 24 .

Palaeastacus meyeri-Devillez and Charbonnier, 2017: 6, tab. 1, fig. 3a-b.

Type material. - Holotype MSNM i7606; three paratypes MSNM i9871, i9893, i9895.

Type locality.-Osteno, Lombardy, Italy.

Type age. - Sinemurian, Early Jurassic.

Description.
Carapace.-Short, spineless rostrum; rounded orbital notch; elongated cephalic and cardiac regions; branchial region short dorsally; deep, wide cervical groove, almost straight, joined to dorsal margin and to antennal groove; deep antennal groove; short, shallow gastro-orbital groove, joined to cervical groove at carapace mid-height; postcervical and branchiocardiac grooves subparallel, shallow, sinuous, strongly inclined, not joined to dorsal margin; postcervical groove joined to hepatic groove; branchiocardiac groove joined to the posterior extremity of hepatic groove; hepatic groove concavoconvex, joined to postcervical groove; inferior groove joined to hepatic groove.

Pleon and uropods.-Somites with wide subtriangular pleurites, with bulge on their basis. 
Thoracic appendages.-Chelate $\mathrm{P} 1$; P1 propodus short, subrectangular; wide P1 fingers, as long as propodus, straight dorsally, equal in length; occlusal margin with short conical teeth, closely spaced; P1 carpus short, subtriangular; elongated P1 merus.

Ornamentation.-Carapace densely covered by small tubercles; cephalic region with some strong and widely spaced spines; antennal region with an antennal spine; pleonal tergites and pleurites covered by small tubercles; $\mathrm{P} 1$ propodus covered by coarse, sub-spinous tubercles; inner margin of dactylus with a row of strong spines directed forward; P1 carpus with coarse tubercles; P1 merus with tubercles.

Discussion.-Like Eryma sinemurianum, Palaeastacus meyeri (Garassino, 1996) is known by some compressed specimens. Firstly assigned to Eryma, this species was integrated to Palaeastacus by Devillez and Charbonnier (2017) because of the carapace groove pattern typical of the genus (short gastro-orbital groove, postcervical and branchiocardiac grooves joined to hepatic groove, hepatic groove sinuous) and the morphology of the P1 chelae (short and subrectangular propodus, short, wide and straight fingers). So, Palaeastacus meyeri is the oldest record of the genus currently known.

The preservation in compression of the specimens limits the comparisons with the other species. However, the carapace ornamentation of P. meyeri, made of small tubercles closely spaced and some strong tubercles in cephalic region, is quite different than the ornamentation of $P$. argoviensis, $P$. foerster $i$ and $P$. numismalis. Moreover, the $\mathrm{P} 1$ propodus of $P$. meyeri is only ornamented by small tubercles, contrary to P. argoviensis, P. edwardsi which have spines on their $\mathrm{P} 1$ propodus.

\subsection{Palaeastacus numismalis (Oppel, 1853) n. comb.}

Fig. 10F-I

Glyphea numismalis (Oppel, 1853): 24, pl. 1, fig. 2; 1854: 62 , pl. 1, fig. 2 .

Eryma numismalis -Oppel, 1861: 356; 1862: 26, pl. 4, fig. 5.-Carter, 1886: 549.-Krause, 1891: 198.-Beurlen, 1928: 158. - Charbonnier et al., 2013: 279, figs 577-579.

Pseudoglyphea numismalis - Van Straelen, 1925: 203, fig. 98. - Woods, 1926: 42. - Glaessner, 1929: 355. -Förster, 1971: 401.-Secrétan, 1972: 618, fig. 8c3.-Feldmann et al., 2002: 26. - Garassino and Rigo, 2008: 70. - Schweitzer et al., 2010: 21.-Klompmaker and Fraaije, 2011: 9.

Type material. - Holotype destroyed during World War II (Charbonnier et al., 2013).

Type locality.-Gomaringen-Hinterweiler, Baden-Württemberg, Germany.

Type age. - Pliensbachian, Early Jurassic.

Description.

Carapace. - Sub-cylindrical carapace; fusiform intercalated plate; deep, wide cervical groove, slightly curved dorsally, joined to dorsal margin and to antennal groove; short, shallow gastro-orbital groove, originating as a slight median inflexion of cervical groove; postcervical and branchiocardiac grooves subparallel, sinuous, joined to dorsal margin; postcervical groove shallow dorsally, becoming deep ventrally, joined to hepatic groove; branchiocardiac groove shallow dorsally, becoming deep ventrally, joined to the posterior extremity of hepatic groove; hepatic groove concavo- convex, joined to postcervical groove; strongly inflated $\omega$ area; inflated $\chi$ area; deep inferior groove, joined to hepatic groove.

Pleon and uropods.-Somites with wide subtriangular pleurites; rounded uropods.

Thoracic appendages.-Chelate P1; P1 propodus short, trapezoidal, slightly globose; narrow dactylar bulge; wide P1 fingers, slightly shorter than propodus; index wider than dactylus; P1 carpus short, subtriangular; elongated P1 merus.

Ornamentation. - Carapace covered by rounded tubercles; pleonal tergites and pleurites covered by wide circular depressions; P1 propodus, carpus and merus covered by rounded tubercles.

Discussion.-The generic assignation of this species remained uncertain for a long time. It was firstly considered as a member of Glyphea Meyer, 1835 and was alternatively assigned to Eryma and Pseudoglyphea Oppel, 1861. The carapace groove pattern, the chelate $\mathrm{P} 1$ and the presence of an intercalated plate support the assignation of this species into Erymidae. Moreover, the absence of junction between the postcervical and branchiocardiac grooves, the junction of both postcervical and branchiocardiac grooves to the sinuous hepatic groove are characteristic of Palaeastacus. Hence, we propose the new combination Palaeastacus numismalis.

The postcervical and branchiocardiac grooves remaining strongly parallel on all their length in P.numismalis is not observed in all the other known Palaeastacus. The shallow depth of the dorsal part of these grooves and the clearly trapezoidal P1 propodus are also unique among the Palaeastacus of the Early and Middle Jurassic. Finally, the homogeneous ornamentation of $P$. numismalis is distinct from the ornamentation of $P$. argoviensis, $P$. edwardsi, and P. meyeri.

\subsection{Palaeastacus argoviensis Förster and Rieber, 1982}

Fig. $11 \mathrm{~A}-\mathrm{C}$

Palaeastacus argoviensis Förster and Rieber, 1982: 774, figs 1-3.-Garassino and Schweigert, 2006: 11.-Schweitzer et al., 2010: 25.

Type material. - Holotype PIM R/36.

Type locality. - Wittnau, Aargau canton, Switzerland.

Type age. - Aalenian, Middle Jurassic.

Description.

Carapace.-Sub-cylindrical carapace; elongated rostrum, with spines; fusiform intercalated plate; branchial region short dorsally; deep cervical groove, slightly curved dorsally, almost straight and subvertical under the level of gastro-orbital groove, joined to dorsal margin and to antennal groove; deep antennal groove; short gastro-orbital groove, originating as a median inflexion of cervical groove; postcervical and branchiocardiac grooves subparallel, narrow, shallow, slightly curved, strongly inclined, not joined to dorsal margin; postcervical groove joined to hepatic groove; branchiocardiac groove joined to the posterior extremity of hepatic groove; deep, wide hepatic groove, concavo-convex, joined to postcervical groove; inflated $\omega$ and $\chi$ areas; inferior groove joined to hepatic groove.

Thoracic appendages. - Chelate P1; P1 propodus short, subrectangular, slightly globose; wide, strongly inflated dactylar bulge; P1 fingers wide, as long as propodus, equal 


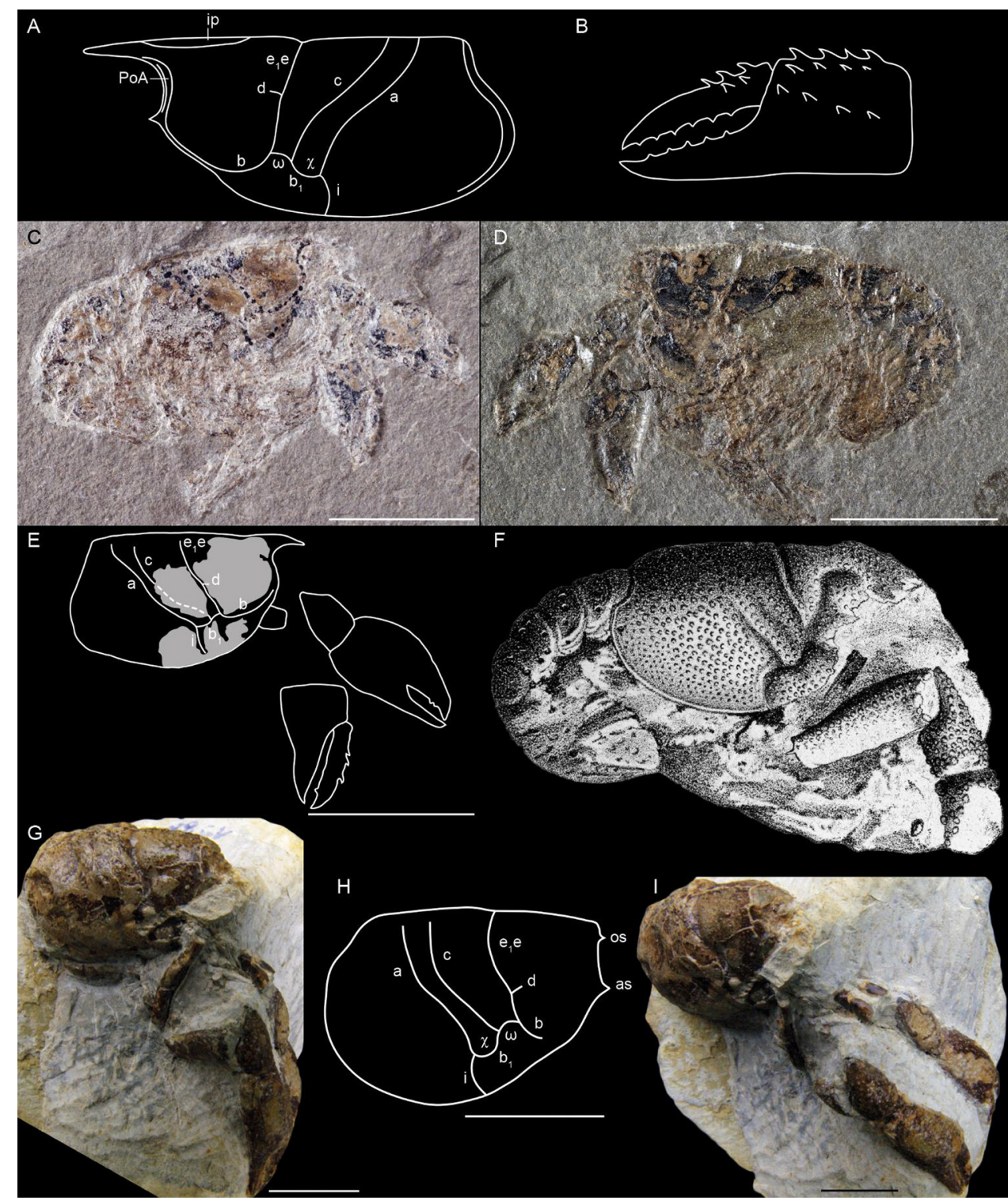

Fig. 10. Morphology of the carapace and of the chela of the first pair of pereiopods of Palaeastacus Bell, 1850 and species from the Early Jurassic. A: typical carapace groove pattern of Palaeastacus; B: typical chela of the first pair of pereiopods of Palaeastacus; C-E: holotype MSNM 17606 of Palaeastacus meyeri (Garassino, 1996) from the Sinemurian of Osteno (Italy): counterpart (C), general view (D), line drawing of the carapace and P1 chelae (E); F: original figure of Oppel (1862: pl. 4, fig. 5) of the holotype of Palaeastacus numismalis (Oppel, 1853) n. comb. from the Pliensbachian of Gomaringen- Hinterweiler (Germany); G-I: specimen of P. numismalis n. comb. from the Pliensbachian of Böbingen an der Rems (Germany) in Thomas Balle's collection, Alfdorf: lateral view (B), anterior view (C), schema of the carapace (D). Scale bars: $1 \mathrm{~cm}$. Abbreviations: a: branchiocardiac groove; as: antennal spine; b: antennal groove; $b_{1}$ : hepatic groove; c: postcervical groove; $d$ : gastro-orbital groove; $\mathrm{e}_{1} \mathrm{e}$ : cervical groove; i: inferior groove; ip: intercalated plate; PoA: postorbital area; os: orbital spine; $\chi$ : attachment site of adductor testis muscle; $\omega$ : attachement site of mandibular muscle. Photographs: A. Garassino (C-D), W. K. Mayer (G, I). Line drawings: J. Devillez.

in length; index wider than dactylus; occlusal margin with short conical teeth, closely spaced; P1 carpus short, subtriangular; elongated P1 merus.

Ornamentation.-Carapace densely covered by small depressions; cardiac region with coarse tubercles; gastric region with two rows of tubercles parallel to the intercalated plate; P1 propodus with strong spines on ventral and dorsal surfaces; P1 fingers covered by widely spaced circular depressions; P1 merus with spines along ventral margin.
Discussion.-Palaeastacus argoviensis is known by a unique specimen. It is assigned to Palaeastacus because of the carapace groove pattern typical of the genus: short gastroorbital groove, postcervical and branchiocardiac grooves joined to the sinuous hepatic groove.

Palaeastacusargoviensis exhibits some particularities among the other species of the genus: the postcervical and branchiocardiac grooves are narrow and shallow, interrupted relatively far from the dorsal margin, and the ornamentation 
made of small depressions and some coarse tubercles in gastric and cardiac regions are unique morphological features. Moreover, the strong sinuosity of the cervical groove of P. argoviensis is not present in P. meyeri, and P. numismalis. The presence of spines on the dorsal side of the $\mathrm{P} 1$ propodus of $P$. argoviensis is also absent in P.edwardsi, P.foersteri, $P$. meyeri and P. numismalis.

\subsection{Palaeastacus edwardsi Étallon, 1861}

Fig. 11D-E

Palaeastacus edwardsi Étallon, 1861: 160, pl. 1, fig. 11.-Oppel, 1862: 45, pl. 11, fig. 3.-Van Straelen, 1925: 288. - Glaessner, 1929: 289. - Förster, 1966: 130. - Förster and Rieber, 1982: 777.-Schweitzer and Feldmann, 2001: 174.-Garassino and Schweigert, 2006: 11.-Schweitzer et al., 2010: 25.

Type material. - Holotype lost.

Type locality.-Etrochey, Côte d'Or department, Bourgogne, France.

Type age. - Callovian, Middle Jurassic.

Description.

Thoracic appendages.-Chelate P1; P1 propodus short, subrectangular, slightly globose; wide index, progressively narrowing to its distal extremity, slightly curved inward; occlusal margin with a few number of very wide, short teeth, widely spaced.

Ornamentation. - P1 propodus covered by closely spaced tubercles, with an irregular longitudinal row of coarse tubercles on dorsal surface; inner margin of P1 propodus with a row of strong spines; index covered by thin tubercles, with an irregular longitudinal row of coarse tubercles on dorsal surface.

Discussion.-Only known by lost isolated and incomplete P1 chela, Palaeastacus edwardsi is assigned to this genus because of the typical shape of the propodus (short, subrectangular, slightly globose), and of the index (wide, slightly longer than propodus).

The occlusal margin of $P$. edwardsi with a few number of very wide teeth and the presence of an irregular row of coarse tubercles on the dorsal surface of the index are unique among the genus Palaeastacus. Moreover, the unique longitudinal row of coarse tubercles on the propodus of P.edwardsi is distinct of what we can observe on $P$. argoviensis, P. foersteri, P. meyeri, and P. numismalis.

\subsection{Palaeastacus foersteri (Feldmann, 1979) n. comb.}

Fig. 12

Eryma foersteri Feldmann, 1979: 2, figs 1-2.-Feldmann and Copeland, 1988: 93, 95.-Feldmann and Titus, 2006: 63. - Feldmann and Haggart, 2008: 1792, 1794.-Schweitzer et al., 2010: 23. - Devillez et al., 2017: 792, tab. 2, fig. 8.

Type material. - Holotype AMNH FI 35862.

Type locality. - Brush Canyon, Wyoming, United States.

Type age. - Callovian, Middle Jurassic.

Description.

Carapace.-Sub-cylindrical carapace; short, spineless rostrum; fusiform intercalated plate; orbital notch widely curved; deep, wide cervical groove, almost straight, joined to dorsal margin; short, shallow gastro-orbital groove, joined to cervical groove at carapace mid-height; postcervical and branchiocardiac grooves subparallel, slightly inclined, not joined to dorsal margin; narrow, shallow postcervical groove; deep branchiocardiac groove, wider than postcervical groove.

Pleon and uropods. - Somites with subrectangular tergites; somites with subtriangular pleurites; telson with a median longitudinal groove; uropods as long as telson; uropodal exopods with a longitudinal carina.

Cephalic appendages. - Wide antennal peduncle; antennas made of numerous and short cylindrical articles.

Thoracic appendages.-Elongated Mxp3; Chelate P1; P1 propodus short, subrectangular; wide P1 fingers, as long as propodus, equal in length; dactylus wider than index; occlusal margin with strong conical teeth closely spaced; P1 carpus short; elongated P1 merus, triangular in section; thin P2-P5.

Ornamentation.-Carapace covered by small, widely spaced circular depressions; telson with four coarse rounded tubercles in its median part, two on each side of the longitudinal groove; $\mathrm{P} 1$ covered by small and shallow rounded depressions; P2-P5 covered by small and widely spaced depressions.

Discussion.-This species is known by a unique compressed specimen. It has been firstly assigned to Eryma, but the absence of junction between the postcervical and branchiocardiac grooves and the morphology of the P1 chelae (short, subrectangular propodus, short and wide fingers) are characteristic of Palaeastacus. So, the new combination Palaeastacus foersteri is here proposed.

This new combination leads to a case of secondary homonymy with Palaeastacus foersteri Taylor, 1979, described the same year than the species of Feldmann. Only the year is mentioned on Taylor's publication, while Feldmann's publication was released on January 30th 1979. According to the article 21.3.2 of the ICZN (1999), if only the year of the publication is mentioned, the date of released is considered to be the last of the year. So, the species described by Feldmann has the precedence and Taylor's species needs a new specific epithet. Hence, we propose the name Palaeastacus uranusiensis nom. nov. for the species previously described by Taylor (1979). This epithet refers to the Uranus glacier, next to the location where the type material was found.

The specimen of $P$. foersteri is crushed so the comparisons with other species of the genus are limited. The carapace and P1 chelae ornamentation of $P$. foersteri is only made of widely spaced depressions. Such ornamentation is unique among Palaeastacus.

\subsection{Fragments attributed to Palaeastacus}

In his review of the erymid lobsters, Förster (1966: 129) assigned to Palaeastacus sp. two fragments of P1 chelae found in the Sinemurian of Lyme Regis (United Kingdom) and stored at the NHMUK $\left(n^{\circ} 60140\right)$ and at the University of Oxford. These specimens were not figured but the description clearly notes the propodus slightly longer than wide, globose, with an oblique row of tubercles on the ventral surface, and the presence of a row of strong spines on inner margin. These morphological features are commonly observed on the P1 of the representatives of Palaeastacus. So, the fossils described 


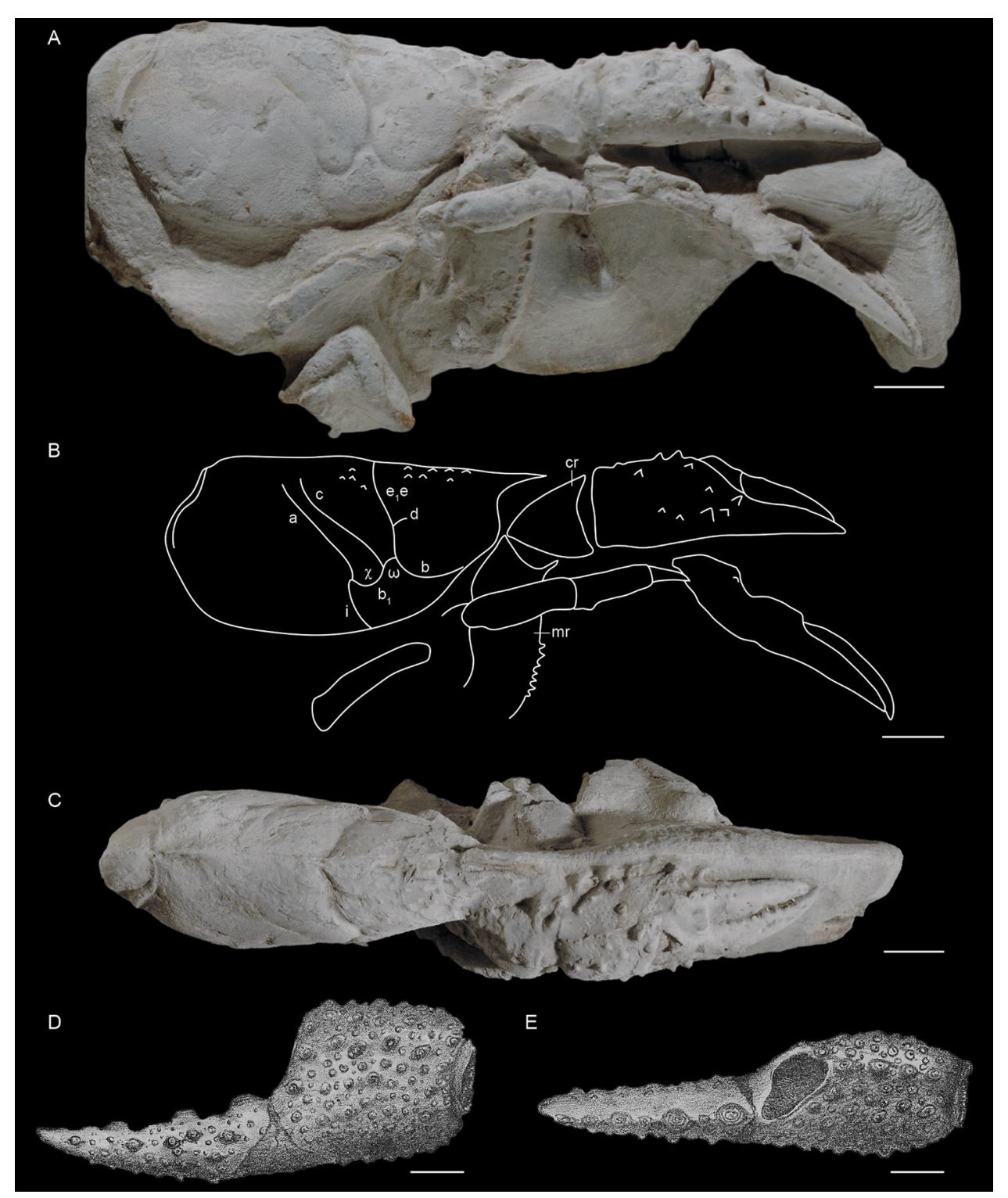

Fig. 11. Palaeastacus argoviensis Förster and Rieber, 1982 from the Aalenian of Wittnau (Switzerland) and Palaeastacus edwardsi Étallon, 1861 from the Callovian of Etrochey (France). A-C: holotype PIM R/36 of P. argoviensis whitened with ammonium chloride: lateral view (A), line drawing (B), dorsal view (C); E-F: original figure of Étallon (1861: pl. 1, fig. 11) of the holotype of P. edwardsi: dorsal view (A), internal view (B). Scale bars: $1 \mathrm{~cm}$. Abbreviations: a: branchiocardiac groove; b: antennal groove; $b_{1}$ : hepatic groove; c: postcervical groove; cr: carpus; d: gastro-orbital groove; $\mathrm{e}_{1} \mathrm{e}$ : cervical groove; i: inferior groove; mr: merus; $\chi$ : attachment site of adductor testis muscle; $\omega$ : attachement site of mandibular muscle. Photographs: C. Klug. Line drawing: J. Devillez.

by Förster (1966) were righteously assigned to this genus and are, with $P$. meyeri, the oldest occurences of this genus.

Frentzen (1937) described Clytia decorata on the basis of an isolated P1 propodus found in the Bajocian of Reutlingen (Germany). Förster (1966), followed by Schweitzer et al. (2010), assigned this species to Palaeastacus. The type is lost since the World War II (Förster, 1966), so only the original figure of Frentzen (1937: pl. 8, fig. 3) can be examined. This propodus does not have any particular feature that could allow a generic and specific assignation. This is maybe not an Erymoidea. So, this specimen is here considered as incertae sedis.

\subsection{Genus Pustulina Quenstedt, 1858}

(Fig. 13A-B)

Pustulina Quenstedt, 1858: 807.-Feldmann et al., 2015: 3.-Devillez et al., 2016: 531, Fig. 1K-L.-Devillez et al., 2017: 792

Phlyctisoma Bell, 1863: 34.-Zittel, 1885: 695.- Secrétan, 1964: 74.-Förster, 1966: 135.

Type species.-Pustulina suevica Quenstedt, 1858 by monotypy.

Emended diagnosis by Devillez et al. (2016). - Fusiform intercalated plate; inflated hepatic, cardiac and branchial 


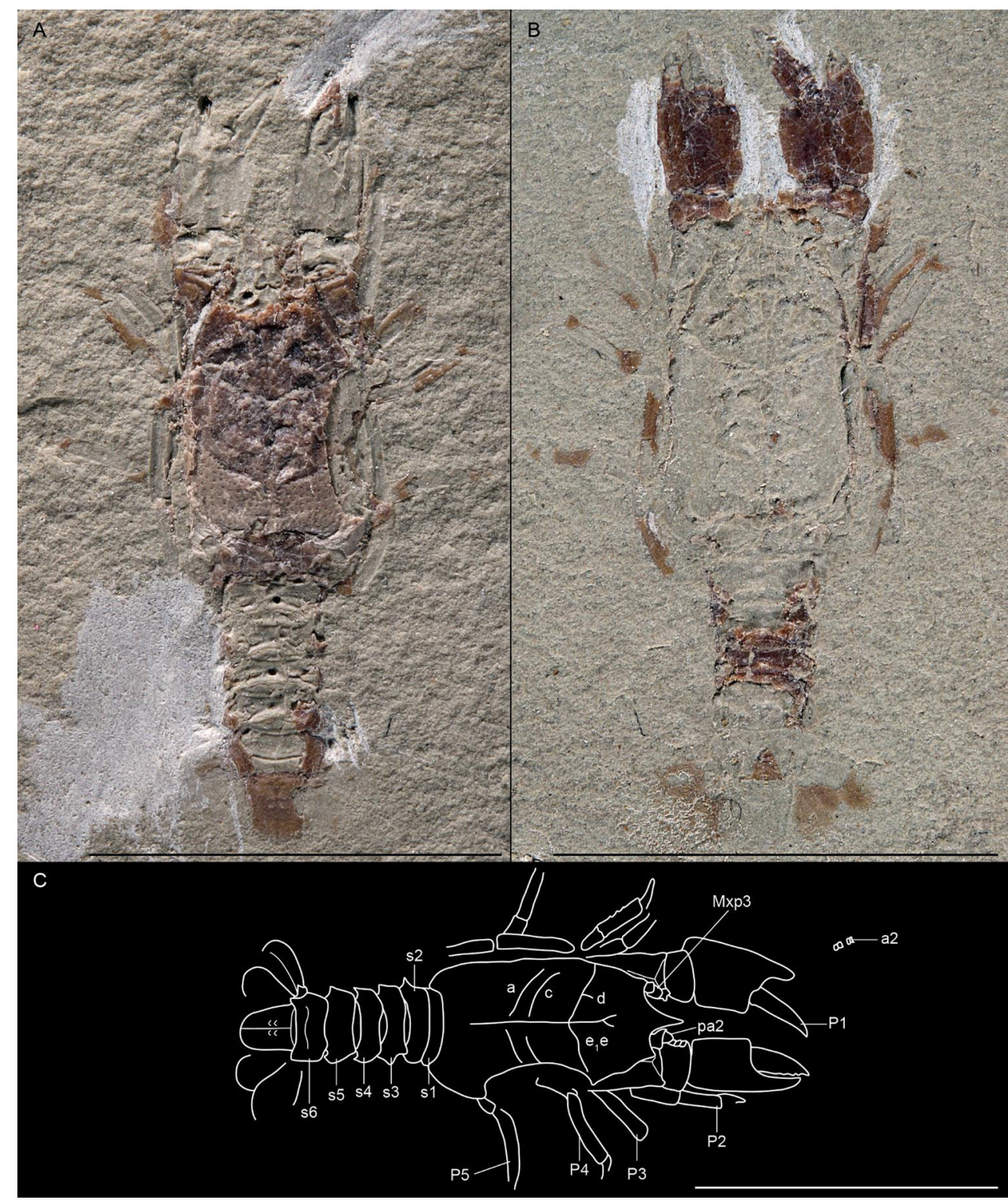

Fig. 12. Palaeastacus foersteri (Feldmann, 1979) n. comb. from the Callovian of Brush Canyon (United States). A-C: holotype AMNH FI 35862: general view (A), counterpart (B), line drawing (C). Scale bars: $1 \mathrm{~cm}$. Abbreviations: a: branchiocardiac groove; a2: antenna; c: postcervical groove; d: gastro-orbital groove; $\mathrm{e}_{1} \mathrm{e}$ : cervical groove; Mxp3: third maxilliped; pa2: antennal peduncle; P1-5: pereiopods; s1-6: pleonal somites. Photographs: S. Thurston. Line drawing: J. Devillez.

regions; deep cervical groove, joined to dorsal margin and to antennal groove; deep, long gastro-orbital groove, originating as a slight median inflexion of the cervical groove, with two divergent, curved branches, delimiting two gastro-orbital lobes; strongly inclined postcervical groove, inflected before joining hepatic groove, not joined to dorsal margin; short and shallow branchiocardiac groove, joined to dorsal margin and not joined to postcervical groove; concave hepatic groove, joined to cervical groove; shallow cardiac groove, straight, inclined forward, rising from postcervical groove, joined to dorsal margin; cephalic region with strongly tuberculate antennal row and distal antennal spine; carapace with tuberculate ornamentation; chelate P1-P3; P1 with strongly tuberculate ornamentation; short P1 propodus with fingers barely longer; P1 dactylus longer than P1 index.

\subsection{Pustulina elegans (Förster, 1966)}

Fig. $13 \mathrm{C}-\mathrm{D}$

Phlyctisoma elegans Förster, 1966: 138, pl. 18, fig. 1. Eryma elegans - Méchin, 1901: 82, pl. 1, figs 8-9.

Pustulina elegans-Schweitzer et al., 2010: 26.

Type material. - Holotype MAN 2016.0.620.

Type locality. - Marbache, Meurthe-et- Moselle departement, Lorraine, France.

Type age.-Bajocian, Middle Jurassic.

Description.

Carapace. - Sub-cylindrical carapace; dorsal margin of the cephalic region slightly curved downward; elongated cardiac region; straight orbital notch; deep, wide cervical groove, curved dorsally, inflected at carapace mid-height, subvertical 


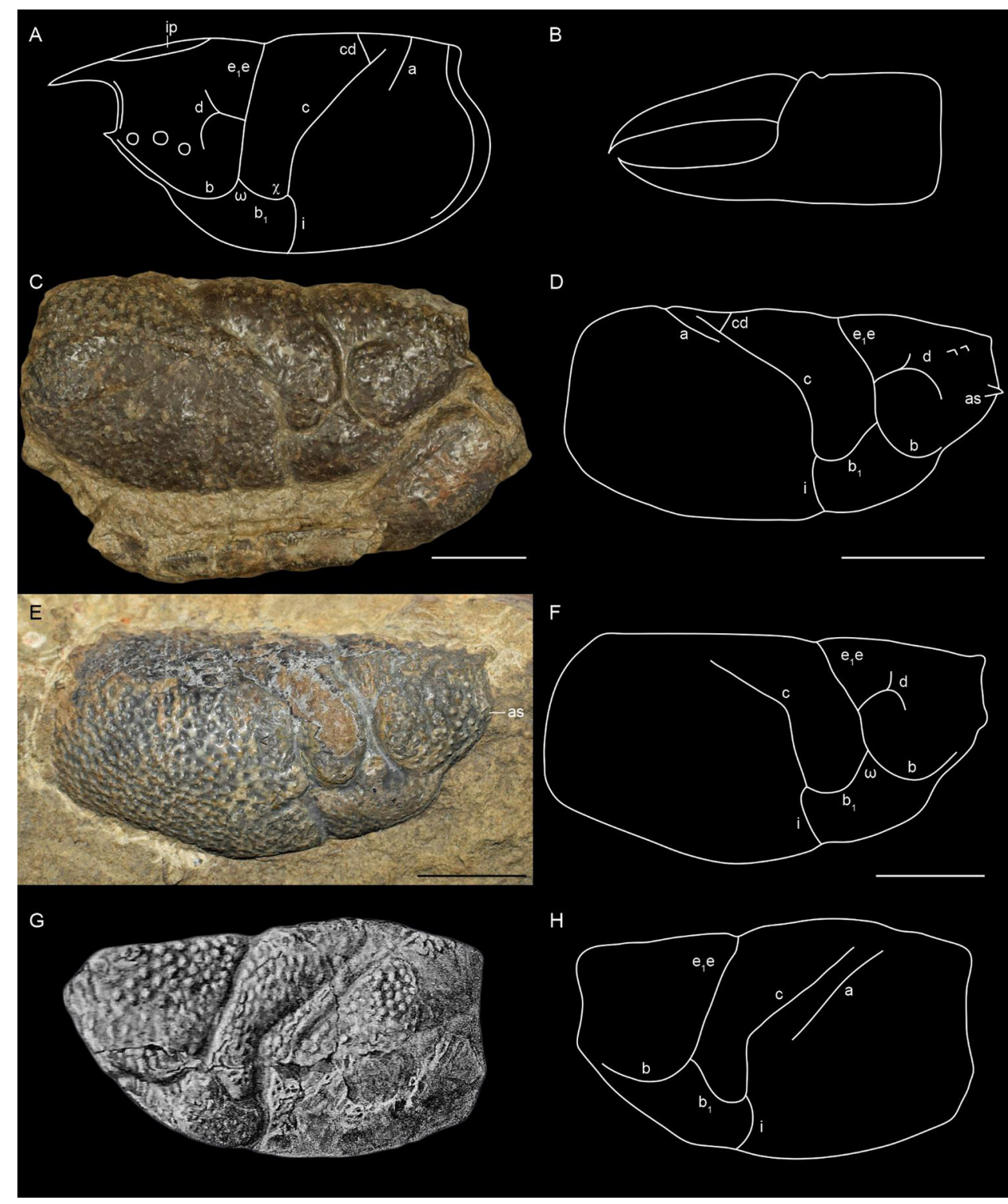

Fig. 13. Morphology of the carapace and of the chela of the first pair of pereiopods of Pustulina Bell, 1863 and species from the Early and Middle Jurassic. A: typical carapace groove pattern of Pustulina; B: typical chela of the first pair of pereiopods of Pustulina; C-D: lectotype MAN 2016.0.620 of Pustulina elegans (Förster, 1966) from the Bajocian of Marbache (France): general view (A), line drawing (B); E-F: lectotype MAN 2016.0.620 of Pustulina calloviensis (Förster, 1966) from the Callovian of Kornberg (Switzerland): general view (A), line drawing (B); G-H: Pustulina sp. from the Early Jurassic of Ilminster (United Kingdom): original figure of the specimen of Woods (1930: pl. 19, fig. 5) (G), line drawing (H). Scale bars: $1 \mathrm{~cm}$. Abbreviations: a: branchiocardiac groove; as: antennal spine; b: antennal groove; $b_{1}$ : hepatic groove; c: postcervical groove; cd: cardiac groove; $d$ : gastro-orbital groove; $\mathrm{e}_{1} \mathrm{e}$ : cervical groove; i: inferior groove; ip: intercalated plate; $\chi$ : attachment site of adductor testis muscle; $\omega$ : attachement site of mandibular muscle. Photographs and line drawings: J. Devillez.

and narrow ventrally, joined to dorsal margin and to antennal groove; deep, narrow antennal groove; deep, elongated gastroorbital groove, oblique, joined to cervical groove at carapace mid-height, with two divergent branches delimiting two gastro-orbital lobes (flat upper lobe, slightly inflated inferior lobe), upper branch shorter than inferior branch; postcervical and branchiocardiac groove very close; deep postcervical groove, inflected at carapace mid-height, strongly inclined dorsally, not joined to dorsal margin; very narrow and very shallow branchiocardiac groove, strongly inclined, joined to dorsal margin and interrupted in banchial region; hepatic groove concave, joined to cervical groove; deep inferior groove, joined to hepatic groove; short, shallow cardiac groove, almost straight, inclined forward, joined to the postcervical groove and to dorsal margin.

Thoracic appendages. - Massive P1 merus.

Ornamentation. - Carapace densely covered by tubercles preceded by depressions, ornamentation denser in branchial region, depressions deeper and wider in branchial region; gastric region with an oblique row of tubercles; antennal 
region with an antennal spine; P1 merus with small depressions.

Discussion.-Pustulina elegans (Förster, 1966) is known by two carapaces (one is lost) assigned to Eryma elegans Oppel, 1861 by Méchin (1901). In his revision of the erymid lobsters, Förster (1966) recognized Méchin's specimens as representatives of a new species assigned to Phlyctisoma Bell, 1863, currently synonym of Pustulina Quenstedt, 1850. The examination of the carapace groove pattern on the type material led us to confirm the assignation to Pustulina because of the elongated gastro-orbital groove with two divergent branches, the inflected postcervical groove joined to the posterior extremity of the concave hepatic groove, the presence of the cardiac groove and the weakly developed branchiocardiac groove.

Pustulina elegans is the oldest known Pustulina and exhibits some atypical characteristics among this genus. The strong inclination and the proximity of the branchiocardiac groove with the dorsal part of the postcervical groove are unique among the genus. Moreover, the almost sinuous trajectories of the hepatic groove, reminding the other erymid genera (excepting Tethysastacus Devillez, Charbonnier, Hyžný and Leroy, 2016) is another characteristic of P. elegans. Moreover, none of the regions of the carapace of this species is inflated, contrary to most of the representatives of Pustulina. In the Early and Middle Jurassic, P. elegans is also the only species to have a clearly identified orbital row, usually found in the representatives of Eryma.

\subsection{Pustulina calloviensis (Förster, 1966)}

Fig. 13E-F

Phlyctisoma calloviensis Förster, 1966: 139, pl. 18, fig. 2.

Pustulina calloviensis-Schweitzer et al., 2010: 26.

Type material. - Holotype NMB F 252.

Type locality. - Kornberg, Aargau canton, Switzerland.

Type age.-Callovian, Middle Jurassic.

Description.

Carapace. - Sub-cylindrical carapace; dorsal margin of the cephalic region slightly curved downward; inflated cardiac, hepatic and branchial regions; dorsal part of cardiac and branchial regions crushed; deep, wide cervical groove, inclined backward and slightly sinuous above the gastroorbital groove, joined to dorsal margin and to antennal groove; shallow antennal groove, curved forward; shallow, narrow gastro-orbital groove, oblique, elongated, originating as a median inflexion of cervical groove, with two divergent branches delimiting two gastro-orbital lobes (flat upper lobe, inflated inferior lobe); deep postcervical groove, inflected at carapace mid-height, strongly inclined dorsally, joined to hepatic groove; deep, wide hepatic groove, concave, joined to cervical groove; cardiac and branchiocardiac grooves notpreserved; inflated $\omega$ area.

Ornamentation.- Heterogeneous ornamentation; cephalic region with an antennal spine; cephalic, cardiac and hepatic regions covered by coarse and widely spaced tubercles; branchial region densely covered by tubercles preceded by wide and deep depressions, depressions wider and deeper dorsally; pterygostomial region covered by small tubercles not strongly prominent, preceded by small depressions.
Discussion.-Pustulina calloviensis (Förster, 1966) is known by a unique specimen assigned to Pustulina because of its carapace groove pattern typical of the genus: wide and elongated gastro-orbital groove with two divergent branches, inflected postcervical groove joined to the posterior extremity of the hepatic groove, hepatic groove concave. The inflated regions posterior to the cervical groove are also typical of Pustulina.

Pustulina calloviensis is distinct from all other species of the genus by the ornamentation of the branchial region of the carapace which has a characteristic scale aspect. It is also the only Pustulina with a $\omega$ area clearly inflated. The dorsal part of its cervical groove is not curved nor sinuous like in P. elegans.

\subsection{Fragments attributed to Pustulina}

Förster (1966) assigned to Pustulina two specimens from the end of the Early Jurassic of United Kingdom previously figured by Woods (1930) as Eryma sp. The first specimen is an isolated carapace showing a postcervical groove not joined to the branchiocardiac groove and joined to the posterior extremity of the hepatic groove, and an ornamentation made of coarse rounded tubercles in the cephalic region and thinner tubercles on the other parts of the carapace (Fig. 13G-H). These characteristics are typical of Pustulina, so we confirm the assignation of the specimen to the genus. The second specimen is a short $\mathrm{P} 1$ propodus bearing short fingers with an almost smooth surface. The absence of ornamentation on the $\mathrm{P} 1$ chelae is not a feature found in any erymid lobster, so this fossil cannot be assigned to Erymoidea.

\subsection{Genus Stenodactylina Beurlen, 1928}

(Fig. 14A-C)

Stenodactylina Beurlen, 1928: 175.-Glaessner, 1969: 456. - Schweigert, 2013: 411. - Devillez et al., 2016: 522, Fig. 1D-F.

Erymastacus Beurlen, 1928: 171 (pars.). - Secrétan, 1964: 71.-Glaessner, 1969: 456 (pars.).-Hyžný et al., 2015: 375.

Type species. - Stenodactylina liasina Beurlen, 1928, by monotypy.

Emended diagnosis. - Fusiform intercalated plate; narrow post-orbital area; deep, very wide cervical groove, joined to dorsal margin and to antennal groove; short gastro-orbital groove originating as a slight median inflexion of cervical groove; postcervical and branchiocardiac grooves nearly parallel; narrow postcervical groove, not joined to branchiocardiac groove and interrupted in hepatic region; branchiocardiac groove strongly inclined, joined to hepatic groove; hepatic groove concavo-convex, joined to cervical groove; inferior groove convex posteriorly, joined to hepatic groove; chelate $\mathrm{P} 1$; P1 propodus rectangular or trapezoidal, with inner margin more compressed than outer margin, with a wide dactylar bulge; P1 with extremely long and slender fingers, equal in length; P1 chela (form I; Fig. 14B) with strong, rectangular or trapezoidal propodus, bearing straight or sinuous fingers, strongly narrowing immediately after their basis; outer margin convex at the basis of the index; P1 chela (form II; Fig. 14C) with trapezoidal propodus, outer margin straight or convex, straight fingers, narrowing gradually to their distal extremity. 


\subsection{Stenodactylina falsani (Dumortier, 1867)}

Fig. 14D-F

Eryma falsani Dumortier, 1867: 86, pl. 15, fig. 1-3.-Van Straelen, 1925: 234. - Vialle, 1948: 62.

Palaeastacus falsani-Förster, 1966: 128.-Förster and Rieber, 1982: 377.-Schweitzer and Feldmann, 2001: 174.-Garassino and Schweigert, 2006: 11.-Schweitzer et al., 2010: 25.

Erymastacus falsani-Glaessner, 1929: 162.-Hyžný et al., 2015: 376.

Stenodactylina falsani-Devillez et al., 2016: 524.

Type material. - Holotype FSL 170514.

Type locality. - Saint-Didier-au-Mont-d'Or, Rhône-Alpes, France.

Type age. - Sinemurian, Early Jurassic.

Description.

Thoracic appendages. - Chelate $\mathrm{P} 1$; P1 propodus elongated, subrectangular, slightly globose dorso-ventrally; longitudinal depression along the inner margin on the ventral surface; slight deviation of the outer margin at the basis of the index; elongated, slender P1 fingers, curved downward; occlusal margin with short conical teeth, regularly spaced.

Ornamentation. - P1 propodus covered by small widely spaced tubercles and with a median row of coarse tubercles; presence of coarse tubercles along the inner margin.

Discussion. - Stenodactylina falsani is only known by two specimens, and only the P1 chelae are preserved. This species, assigned to Eryma, Palaeastacus, Erymastacus and Stenodactylina according to different authors, exhibits a subrectangular and elongated P1 propodus, angular in shape, with an inflated median part, a deviation of outer margin at the basis of the index. This propodus bears slender, straight fingers, of constant width. These characteristics are typical of the P1 chelae of the representatives of Stenodactylina. So, we follow Devillez et al. (2016) and we maintain the assignation of this species to Stenodactylina.

Stenodactylina falsani is the oldest species of the genus currently known. As it is only known by some P1 chelae, the comparisons are limited to the other species whose the P1 chelae are known. The fine ornamentation around a unique median row of coarse tubercles and the absence of spines on inner margin of the propodus of $S$. falsani are distinct from all other species of Stenodactylina.

\subsection{Stenodactylina liasina Beurlen, 1928}

Fig. 14G-H

Stenodactylina liasina Beurlen, 1928: 176, pl. 6, fig. 4.-Glaessner, 1929: 380.-Förster and Rieber, 1982: 377.-Schweitzer et al., 2010: 26.-Schweigert, 2013: 410, fig. 1.-Hyžný et al., 2015: 376, fig. 3D.

Type material.-Holotype SMNS 7785.

Type locality.-Holzmaden, Baden- Württemberg, Germany.

Type age.-Toarcian, Early Jurassic.

Description.

Thoracic appendages. - Chelate P1; P1 propodus elongated, subrectangular, slightly globose dorso-ventrally; strong deviation of the outer margin at the basis of the index; narrow, inflated dactylar bulge; slender, straight index, with the same width on all its length.

Ornamentation. - P1 propodus covered by widely spaced tubercles, with a longitudinal median row of strong tubercles; inner margin with a row of spines directed forward.

Discussion.-The comparisons of S. liasina with other species of the Early and Middle Jurassic are limited to those known by their P1 chelae: S. burgundiaca, S. deslongchampsi, S. falsani, S. lagardettei, S. rogerfurzei and S. spinosa. It is easy to distinguish $S$. liasina from these species because of the very strong deviation of the outer margin of the propodus at the basis of the index. S. liasina is also the only Stenodactylina to have two longitudinal rows of coarse tubercles on its propodus.

\subsection{Stenodactylina spinosa (Étallon, 1861) n. comb.}

Fig. 14I-K

Macrourites spinosus Étallon, 1861: 170, pl. 1, fig. 10.-Förster and Rieber, 1982: 777.

Palaeastacus spinosus - Van Straelen, 1925: 288. - Glaessner, 1929: 290. - Förster, 1966: 129, pl. 17, fig. 5. - Schweitzer and Feldmann, 2001: 174.-Garassino and Schweigert, 2006: 11.-Schweitzer et al., 2010: 26.

Type material. - Lost (after Förster, 1966).

Type locality.-Les Nans, Jura departement, FrancheComté, France.

Type age. - Toarcian, Early Jurassic.

Description.

Thoracic appendages. - Chelate P1; P1 propodus elongated, subrectangular, slightly globose dorso-ventrally; rounded outer margin, with a slight deviation at the basis of the index; slender index; dactylar bulge not well-marked.

Ornamentation. $-\mathrm{P} 1$ propodus covered by small tubercles, with two longitudinal rows of coarse tubercles on ventral surface, with spines in quincunx, directed forward on inner margin.

Discussion. - The holotype of this species is lost (Förster, 1966). On the original figure we can see that the $\mathrm{P} 1$ propodus is elongated, slightly globose, with a deviation of the outer margin at the basis of the index and a slender index. Such morphology is characteristic of Stenodactylina. Hence, we assigned this species to this genus and we propose the new combination Stenodactylina spinosa (Étallon, 1861).

Förster (1966) assigned some other specimens to this species, which was considered to be a Palaeastacus. The first is a $\mathrm{P} 1$ propodus similar to that of the type (Fig. 14K). But the other P1 chelae from the Aalenian stored in the collections of the FSL have a morphology characteristic of Eryma: a propodus compressed dorso-ventrally, fingers curved inward, progressively narrowing to their distal extremity.

Stenodactylina spinosa is only known by its P1 chelae and can only be compared to other species whose P1 chelae are preserved (S. burgundiaca, S.deslongchampsi, S.falsani, S. lagardettei, S. liasina, S. rogerfurzei). S. spinosa is distinct from S. burgundiaca, S. deslongchampsi, S.falsani, and $S$. liasina by its longitudinal rows of coarse tubercles on the propodus. Moreover, the absence of depressions in the ornamentation of the propodus of S. spinosa is distincts from S. lagardettei, S. rogerfurzei. 


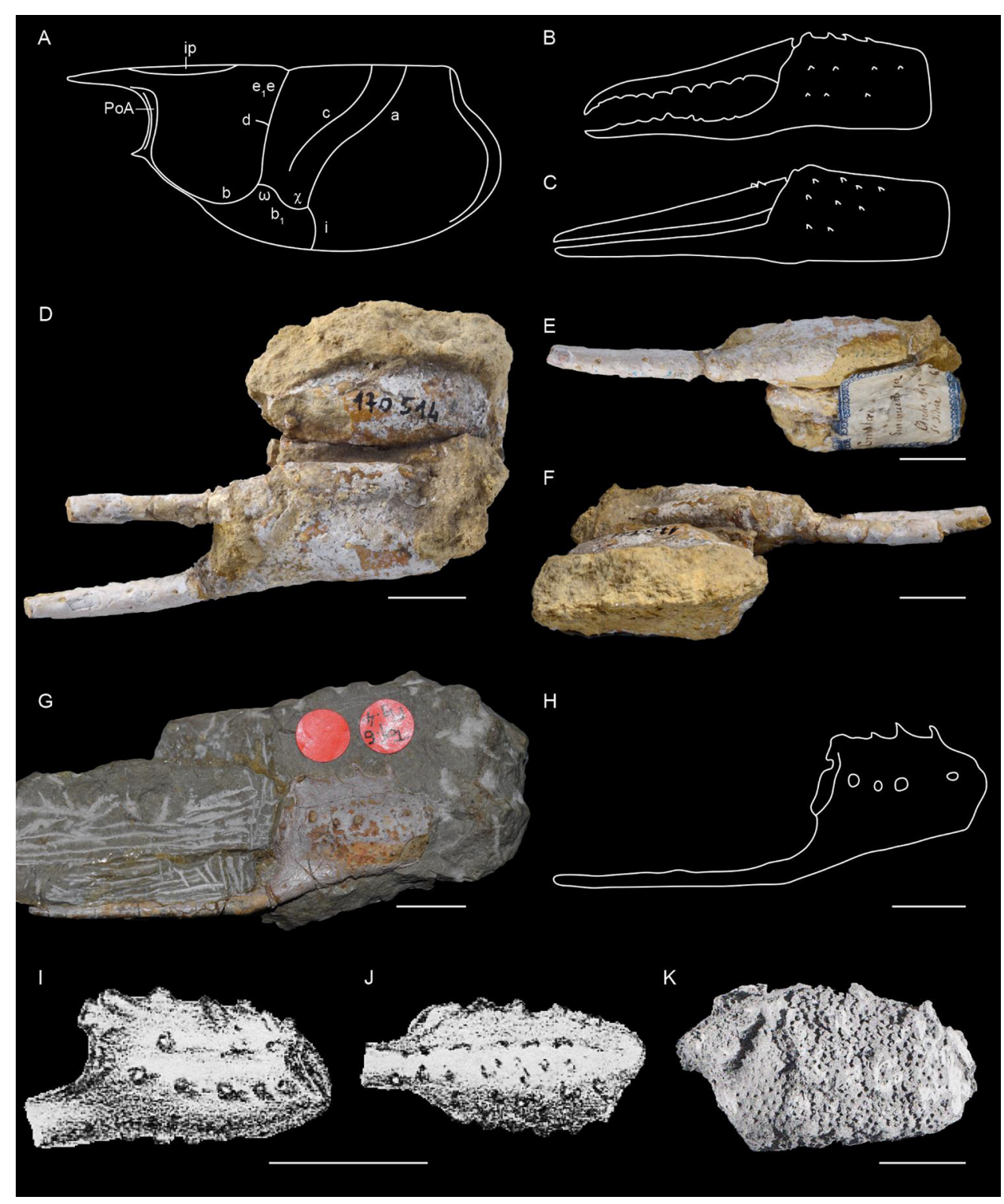

Fig. 14. Morphology of the carapace and of the chela of the first pair of pereiopods of Stenodactylina Beurlen, 1928 and species from the Early Jurassic. A: typical carapace groove pattern of Stenodactylina; B: form I of chela of the first pair of pereiopods of Stenodactylina; C: form II of chela of the first pair of pereiopods of Stenodactylina; D-F: holotype FSL 170514 of Stenodactylina falsani (Dumortier, 1867) from the Sinemurian of Saint-Didier-au-Mont-d'Or (France): ventral view (D), external view (E), internal view (F); G-H: Holotype SMNS 7785 of Stenodactylina liasina Beurlen, 1928 from the Toarcian of Holzmaden (Germany): general view (G), line drawing (H); I-J: original figures of Étallon (1861: pl. 1, fig. 10) of the holotype of Stenodactylina spinosa (Étallon, 1861) n. comb. from the Toarcian of Les Nans (France): ventral view (I), outer view (J); K: original figure of Förster (1966: pl. 17, fig. 5) of a specimen of S. spinosa from the Toarcian of Perrigny (France). Scale bars: $1 \mathrm{~cm}$. Abbreviations: a: branchiocardiac groove; b: antennal groove; $b_{1}$ : hepatic groove; c: postcervical groove; d: gastro-orbital groove; $\mathrm{e}_{1} \mathrm{e}$ : cervical groove; i: inferior groove; ip: intercalated plate; PoA: post-orbital area; $\chi$ : attachment site of adductor testis muscle; $\omega$ : attachement site of mandibular muscle. Photographs: L. Cazes (D-F), J. Devillez (G). Line drawings: J. Devillez.

\subsection{Stenodactylina deslongchampsi (Van Straelen, 1925)}

Fig. 15A

Eryma deslongchampsi Van Straelen, 1925: 237.--Glaessner, 1929: 153. - Secrétan, 1964: 68.-Crônier and Courville, 2004: 1006.-Feldmann and Titus, 2006: 63.-Schweitzer et al., 2010: 23.
Eryma aalensis-Eudes-Deslongchamps, 1878: 7, pl. 1, fig. 11.-Hée, 1924: 131. 524.

Stenodactylina deslongchampsi-Devillez et al., 2016:

Type material.-Destroyed during the World War II (Förster, 1966).

Type locality.-May-sur-Orne, Calvados departement, Normandy, France. 
Age type.-Aalenian, Middle Jurassic.

Description.

Carapace.-Sub-cylindrical carapace; short post-orbital area; elongated cephalic region, representing almost half of the length of the carapace, compressed dorso-ventrally; wide cervical groove, strongly inclined, concav forward, joined to dorsal margin and to antennal groove; deep, wide antennal groove; shallow gastro-orbital groove, oblique, originating as a slight median inflexion of cervical groove, with a subvertical branch directed towards dorsal margin; postcervical and branchiocardiac grooves subparallel, almost straight, strongly inclined; narrow postcervical groove, not well- marked dorsally, becoming deeper and wider toward its ventral extremity, not joined to dorsal margin and interrupted in hepatic region; deep, wide branchiocardiac groove, not joined to dorsal margin, joined to hepatic groove; hepatic groove concavo-convex, joined to cervical groove; flat $\omega$ and $\chi$ areas; deep inferior groove, joined to hepatic groove.

Thoracic appendages. - Chelate $\mathrm{P} 1$; P1 propodus trapezoidal, with a slightly rounded inner margin; slender, elongated P1 fingers, straight dorsally; P1 carpus short, subtriangular; elongated $\mathrm{P} 1$ merus, triangular in section, with a short process at outer side of its ventral extremity.

Ornamentation.-Carapace and chelipeds covered by small tubercles.

Discussion. - Stenodactylina deslongchampsi is known by a specimen showing the carapace connected to a P1. This fossil has been destroyed during the World War II (Förster, 1966), so the original figure of Eudes-Deslongchamps (1878) is the only representation of the specimen. It has been originally assigned to Eryma aalensis (Quenstedt, 1858) (Eudes-Deslongchamps, 1878) and then recognized as a distinct species by Van Straelen (1925): Eryma deslongchampsi. Careful examination of the figure of the specimen leds to assign the species to another genus. Indeed, there is no junction between the postcervical and branchiocardiac grooves, and the postcervical is interupted in hepatic region while the branchiocardiac groove is joined to the hepatic groove. This groove pattern is characteristic of Stenodactylina and support the assignation of the species to this genus (Devillez et al., 2016).

The shape of the carapace of Stenodactylina deslongchampsi is particular among the genus, and the erymid lobsters: the strongly elongated cephalic region is compressed dorso-ventrally, with an antennal groove strongly straightened up as consequence. The strong obliquity of the gastro-orbital groove and the presence of a subvertical branch at the distal extremity of this groove are unique features among the other species of Stenodactylina. Some other characteristics of the carapace groove pattern allow the distinction between $S$. deslongchampsi and some other species. Hence, the wellmarked sinuosity of the cervical groove of $S$. deslongchampsi is absent in S.burgundiaca, S.guisei, S.lagardettei and $S$. walkerae. The inclination of the postcervical and branchiocardiac grooves is stronger in S.deslongchampsi than in S. burgundiaca, S. guisei and S.walkerae. Finally, the ornamentation of $S$. deslonchampsi does not have particular arrangement nor coarse elements contrary to S.falsani, S. lagardettei, S.liasina, S. rogerfurzei, S. spinosa and $S$. walkerae.

\subsection{Stenodactylina guisei (Wright, 1881) n. comb.}

Fig. 15B-J

Eryma guisei Wright, 1881: 56, figs 1-2.-Förster, 1966: 100, fig. 15, pl. 14, fig. 5 (non 4). - Taylor, 1979: 4. - Secrétan, 1984: 517.-Crônier and Courville, 2004: 1007. - Etter, 2004: 384. - Feldmann and Titus, 2006: 64. - Feldmann and Haggart, 2008: 1794. - Schweitzer et al., 2010: 24. - Astrop, 2011: 115, 118, 119, 120, annexes 1-2.

Eryma lemairei Méchin, 1901: 80, figs 3-4. - Van Straelen, 1925: 240.-Glaessner, 1929: 155.-Schweitzer et al., 2010: 23. nov. syn.

Eryma bedelta-Woods, 1930: 74, pl. 20, figs 3-7.

Type material. - Holotype not located.

Type locality. - Leckhampton Hill, Gloucestershire, United Kingdom.

Type age. - Aalenian, Middle Jurassic.

Description.

Carapace.-Sub-cylindrical carapace; spiny rostrum; fusiform intercalated plate; narrow post-orbital area; high, inflated branchial region, with a strongly rounded ventral margin; inflated pterygostomial region; deep, wide cervical groove, almost straight, joined to dorsal margin and to antennal groove; deep, wide antennal groove; short gastro-orbital groove, wide and deep, originating as a slight median inflexion of cervical groove; postcervical and branchiocardiac grooves subparallel, almost straight, separated by a narrow crest; deep postcervical groove, strongly inclined, not joined to dorsal margin, interrupted in hepatic region; deep branchiocardiac groove, strongly inclined, joined to dorsal margin and to hepatic groove; wide, shallow hepatic groove, concavo-convex, joined to cervical groove; inflated $\omega$ and $\chi$ areas, $\omega$ area ventrally delimited by a shallow depression extending between cervical and hepatic grooves; inferior groove strongly curved forward, joined to hepatic groove.

Ornamentation.-Carapace covered by small tubercles preceded by crescent-shaped depressions, ornamentation coarser and more widely spaced in gastric, antennal, cardiac and hepatic regions; post-orbital area with small tubercles.

Discussion.-This species described by Wright (1881) from a not located carapace was firstly assigned to Eryma. We notice the following characteristics on the figure of this specimen from the Aalenian of Leckhampton Hill: a high branchial region widely rounded ventrally, giving a paunchy aspect to the carapace, a $\omega$ area clearly bounded by a depression running between the antennal and hepatic grooves, an almost straight branchiocardiac groove and a homogeneous ornamentation. The representation of the postcervical groove is quite strange because of its junction to the branchiocardiac groove located very low on the carapace. So, it could supports the assignation to Eryma. However, there are some specimens in the collections of the NHMUK identified as "Eryma guisei", assigned to Eryma bedelta by Woods (1930), and mentionned by Förster (1966). Among these specimens, one was found in the same locality than the type of Wright: the Aalenian of Leckhampton Hill (Fig. 15F). The comparison of the specimens of the NHMUK with the figure of the type shows strong similarities between them: high carapace with a paunchy aspect, well-marked $\omega$ area, branchiocardiac groove slightly curved or almost straight, 


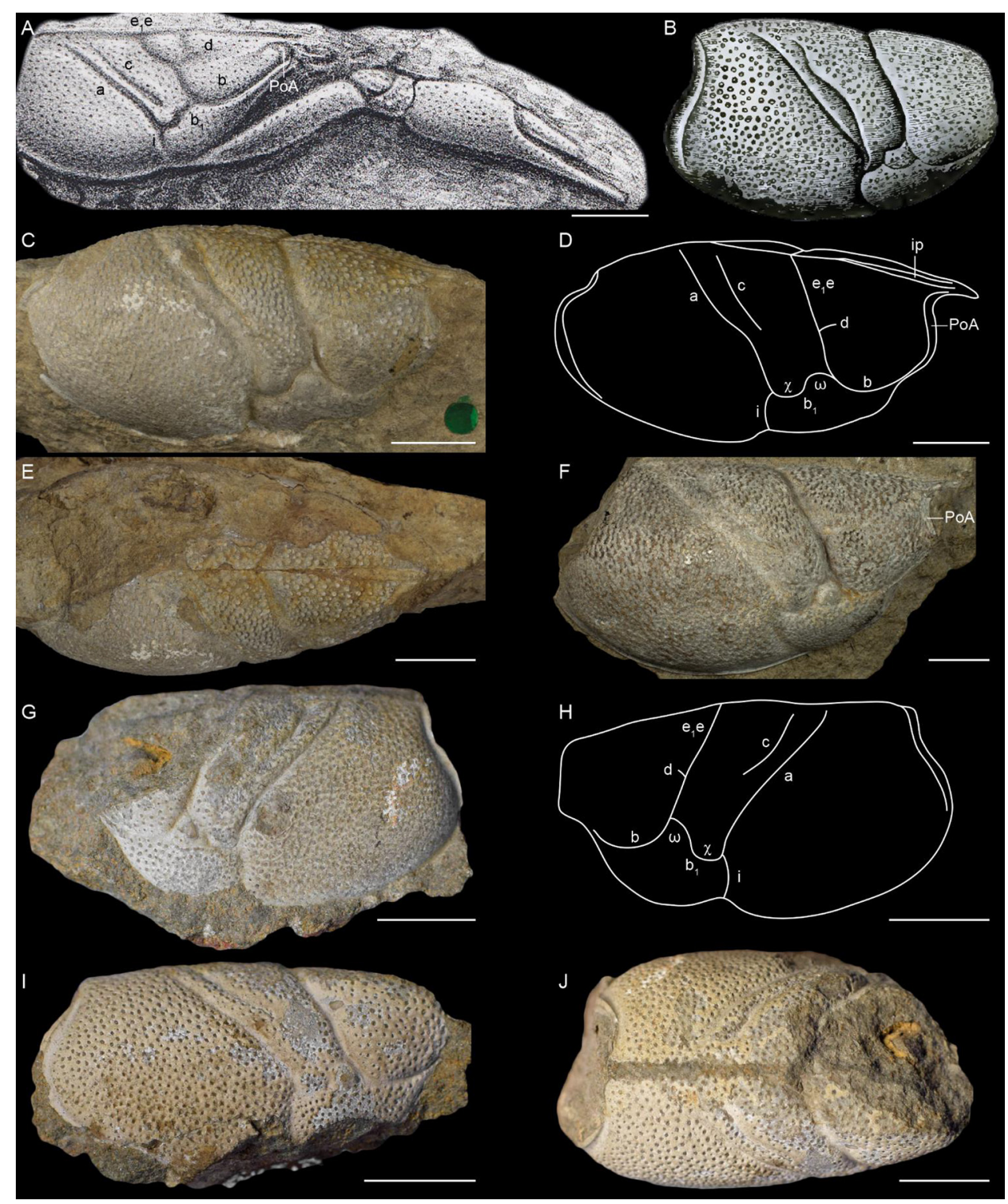

Fig. 15. Stenodactylina deslongchampsi (Van Straelen, 1925) and Stenodactylina guisei (Wright, 1881) n. comb. A: original figure of EudesDeslongchamps (1878: pl. 1, fig. 11) of the holotype of S. deslongchampsi from the Aalenian of May-sur-Orne (France); B: original figure of Wright (1881: fig. 1) of the holotype of S. guisei n. comb.; C-E: specimen NHMUK In.27142 of S. guisei n. comb. from the Bajocian of Waltham on the Wolds (United Kingdom): lateral view (C), line drawing (D), dorsal view (E); F: specimen NHMUK I.1036 of $S$. guisei n. comb. from the Aalenian of Leckhampton Hill (United Kingdom); G-J: holotype MAN 2015.0.227 of Eryma lemairei Méchin, 1901 from the Toarcian of Chavigny (France): left lateral view $(\mathrm{F})$, schema $(\mathrm{G})$, right lateral view $(\mathrm{H})$, dorsal view (I). Scale bars: $1 \mathrm{~cm}$. Abbreviations: a: branchiocardiac groove; $b$ : antennal groove; $b_{1}$ : hepatic groove; $c$ : postcervical groove; $d$ : gastro-orbital groove; $e_{1} e$ : cervical groove; i: inferior groove; ip: intercalated plate; PoA: post-orbital area; $\chi$ : attachment site of adductor testis muscle; $\omega$ : attachement site of mandibular muscle. Photographs: J. Devillez. Line drawings: J. Devillez.

homogeneous ornamentation. These similarities led us to consider the specimen figured by Wright (1881) and those of the NHMUK to belong to the same species. The absence of junction between the postcervical and branchiocardiac grooves and the interruption of the postcervcical groove in the hepatic region observed on the fossils are characteristic of Stenodactylina and support the assignation of E. guisei to this genus. So, we propose the new combination Stenodactylina guisei (Wright, 1881).
Eryma lemairei Méchin, 1901 was found in the Aalenian of Chavigny (France; Fig. 15G-J) and exhibits characteristics similar to those of S. guisei: high branchial region, strongly rounded ventrally, postcervical and branchiocardiac grooves not joined, slightly curved postcervical groove interrupted in the dorsal part of the hepatic region, slightly curved branchiocardiac groove, inflated $\omega$ and $\chi$ areas, with a ventral delimitation for the $\omega$ area, homogeneous ornamentation made of small tubercles and depressions. Considering all these 
elements, we consider E. lemairei to be a junior synonym of $S$. guisei. It is moreover the only occurrence of this species reported outside United Kingdom.

Stenodactylina guisei is only known by its carapace, so it can only be compared to the other species of the genus whose carapace is preserved: S. burgundiaca, S. deslongchampsi, $S$. lagardettei and $S$. walkerae. The very high branchial region, the paunchy aspect of the carapace and the strong inflation of the $\omega$ area are characteristics only found in S.guisei. The relatively short length of the postcervical groove of $S$. guisei allows its distinction from S. burgundiaca, S. deslongchampsi, S. lagardettei and S. walkerae. Moreover, S. guisei has an inflation of both $\omega$ and $\chi$ areas contrary to $S$. deslongchampsi and S. walkerae.

\subsection{Stenodactylina lagardettei (Hyžný, Schlögl, Charbonnier, Schweigert, Rulleau and Gouttenoire, 2015)}

Fig. 16

Erymastacus lagardettei Hyžný, Schlögl, Charbonnier, Schweigert, Rulleau and Gouttenoire, 2015: 376, fig. 3F-G, figs 5-11.

Stenodactylina lagardettei-Devillez et al., 2016: 524. 346.

Type material. - Holotype PF Aal 345, 1 paratype PF Aal

Type locality.-Belmont-d'Azergues, Rhône department, Rhône-Alpes, France.

Type age.-Aalenian, Middle Jurassic.

Description.

Carapace.-Sub-cylindrical carapace; spineless rostrum; fusiform intercalated plate; deep, wide cervical groove, joined to dorsal margin and to antennal groove; deep antennal groove; short, oblique gastro-orbital groove, originating as a median inflexion of cervical groove; postcervical and branchiocardiac grooves subparallel; deep postcervical groove, slightly curved, wider in its dorsal part, not joined to dorsal margin and interupted in hepatic region; deep, wide branchiocardiac groove, not joined to dorsal margin and joined to the posterior extremity of hepatic groove; hepatic groove concavo-convex, joined to cervical groove; slightly inflated $\omega$ and $\chi$ areas; deep, very wide inferior groove, joined to hepatic groove.

Cephalic appendages.-Wide epistome, with a linear contact with the carapace; smooth, subrectangular mandibles.

Thoracic appendages.-Chelate $\mathrm{P} 1$, with two distinct morphologies; P1 propodus of form I massive, subrectangular, slightly globose; wide, inflated dactylar bulge; deviation of outer margin at the basis of the index; slender, elongated P1 fingers, sometimes slightly sinuous, slightly curved downward, with a terminal hook; occlusal margins with short, sharp and widely spaced teeth; P1 propodus of form II massive, trapezoidal, slightly globose; wide, inflated dactylar bulge; deviation of outer margin at the basis of the index; elongated P1 fingers, straight, index wide at its basis; occlusal margin with short conical teeth; P1 carpus short, subtriangular; elongated P1 merus, with a moderately elongated process at outer side of its ventral extremity.

Ornamentation.-Carapace covered by small tubercles preceded by depressions; intercalated plate with two rows of small tubercles; gastric region with a row of coarse tubercles parallel to the intercalated plate, and with some coarse tubercles irregularly disseminated; P1 propodus densely covered by small depressions, with longitudinal rows of coarse tubercles on dorsal and ventral surfaces, inner margin with short spines directed forward; dactylus with two proximal spines directed forward; P1 carpus with spines on its upper margin, and covered by coarse tubercles widely spaced and by small tubercles preceded by depressions; P1 merus covered by small depressions, spines along ventral margin.

Discussion. - The description of this species has led to the restoration of the genus Erymastacus Beurlen, 1928 by Hyžný et al. (2015), who have not considered its type species, Glyphea ornati Quenstedt, 1858, as a representative of Eryma Meyer, 1840a. The fossils from Belmont have the carapace connected to their P1, so Hyžný et al. (2015) have pointed out the similarities of these chelae with those of Stenodactylina. The confusion about the type species of Erymastacus led them to consider Stenodactylina as a junior synonym of this genus. This confusion was corrected by Devillez et al. (2016), who reinstaured the validity of Stenodactylina and the synonymy between Eryma and Erymastacus. The specimens of Erymastacus lagardettei can be assigned to Stenodactylina on the basis of the shape of their P1 chelae: elongated propodus, subrectangular, slightly globose, with a deviation of the outer margin at the basis of the index, slender fingers, strongly elongated and sometime sinuous (Fig. 16A). These fossils have allowed the identification of the carapace groove pattern of Stenodactylina. Indeed, in 2015 this genus was known by only two species decribed from an isolated P1 chela: S. liasina Beurlen, 1928 and S. rogerfurzei Schweigert, 2013.

The examination of the P1 chelae of $S$. lagardettei revealed two morphologies (Fig. 16A-B) interpreted as a possible sexual dimorphism by Hyžný et al. (2015).

The fine ornamentation of S.lagardettei, made of tubercles and depressions, is quite different from that of $S$. deslongchampsi and S. walkerae. Moreover, the row of coarse tubercles parallel to the intercalated plate is absent in S. burgundiaca, S.deslongchampsi, S. guisei and S.walkerae. S. lagardettei has also an orbital row, which is absent in S. burgundiaca, S. deslongchampsi, and S.guisei. The postcervical groove of $S$. lagardettei is more elongated than in S. guisei, and it is more inclined and less curved than that of $S$. burgundiaca and $S$. walkerae. Both $\omega$ and $\chi$ areas are inflated in $S$. lagardettei contrary to $S$. deslongchampsi and $S$. walkerae. Finally, the presence of some longitudinal rows of coarse tubercles on the $\mathrm{P} 1$ propodus also distincts S. lagardettei from S. burgundiaca, S. deslongchampsi, and S. liasina.

\subsection{Stenodactylina rogerfurzei Schweigert, 2013}

Fig. 17A-D

Stenodactylina rogerfurzei Schweigert, 2013: 411, fig. 3.-Hyžný et al., 2015: 376, fig. 3E.

Type material. - Holotype SMNS 70043.

Type locality.-Scheffheu Hill, Baden- Württemberg, Germany.

Type age.-Aalenian, Middle Jurassic.

Description. 


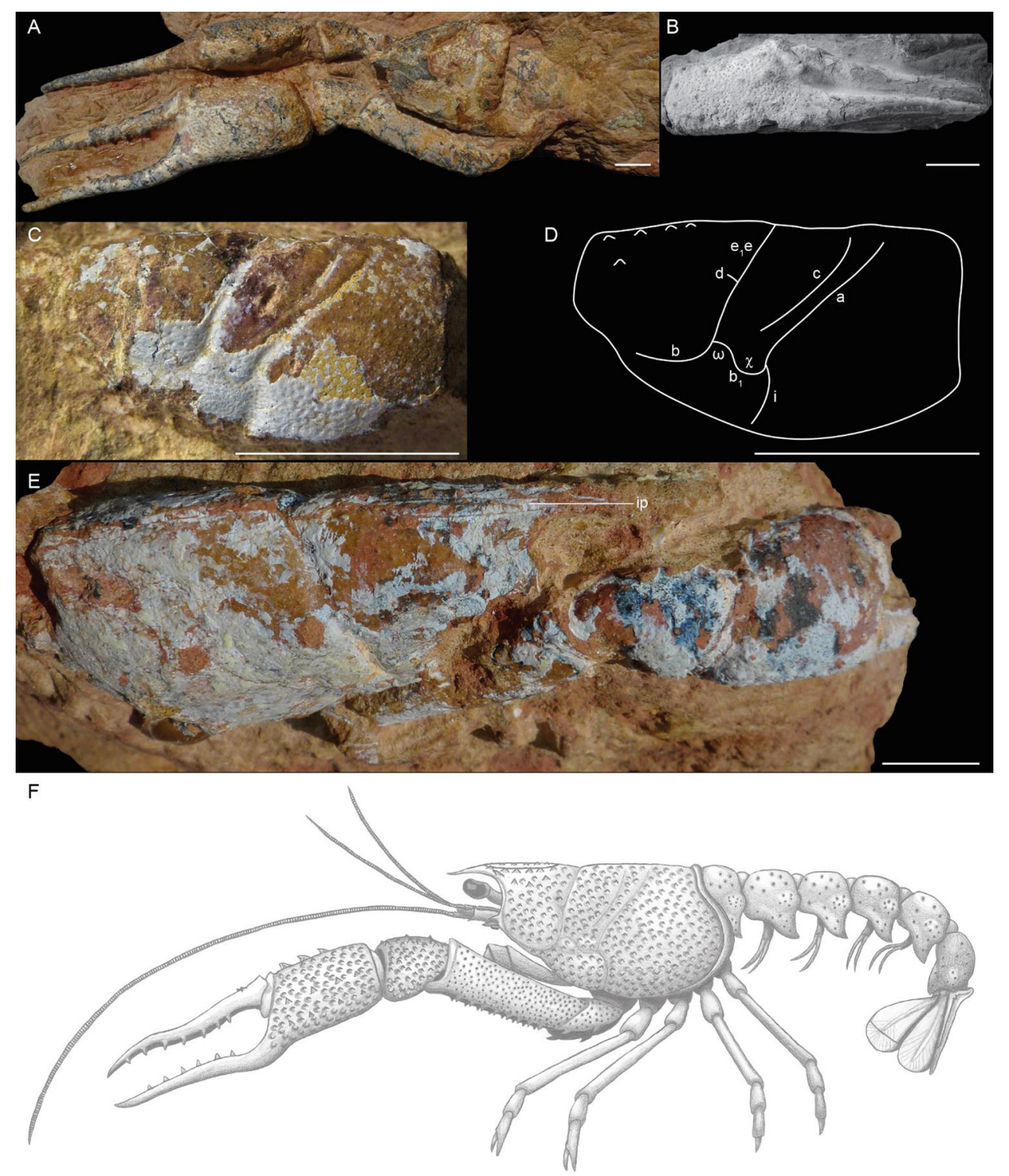

Fig. 16. Stenodactylina lagardettei (Hyžný, Schlögl, Charbonnier, Schweigert, Rulleau and Gouttenoire, 2015) from the Aalenian of Belmontd'Azergues (France). A: holotype PF Aal 345; B: specimen KGP-MH/BE-008 whitened with ammonium chloride; C-D: specimen MHNL 20 103064: lateral view (C), line drawing (D); E: paratype PF Aal 346. Scale bars: $1 \mathrm{~cm}$. Abbreviations: a: branchiocardiac groove; b: antennal groove; $b_{1}$ : hepatic groove; $c$ : postcervical groove; $d$ : gastro-orbital groove; $\mathrm{e}_{1} \mathrm{e}$ : cervical groove; i: inferior groove; ip: intercalated plate; $\chi$ : attachment site of adductor testis muscle; $\omega$ : attachement site of mandibular muscle. Photographs: M. Hyžný. Line drawing and drawing: J. Devillez.

Thoracic appendages. - Chelate $\mathrm{P} 1$; $\mathrm{P} 1$ propodus elongated, subrectangular, slightly compressed dorso-ventrally; strong deviation of the outer margin at the basis of the index; narrow, inflated dactylar bulge; index slender and almost straight.

Ornamentation. - P1 propodus covered by small tubercles preceded by crescent-shaped depressions; oblique median row of coarse tubercles on ventral surface; four oblique rows of coarse tubercles on dorsal surface; inner margin with coarse tubercles in quincunx.

Discussion. - This species is known by a unique fragment of P1 chela. Stenodactylina rogerfurzei is assigned to Stenodactylina because of its elongated, subrectangular propodus, angular in shape, slightly globose, with an inner margin more compressed than the outer margin, the deviation of the outer margin at the basis of the index, and its wellmarked dactylar bulge.

Comparisons of Stenodactylina rogerfurzei with other representatives of Stenodactylina are limited to the P1 chela. The presence of longitudinal rows of coarse, widely spaced tubercles distincts S.rogerfurzei from all Stenodactylina species whose P1 chelae are known, excepting S. lagardettei and S. spinosa. S. rogerfurzei is different from these two species by its stronger deviation of the outer margin at the basis of the index. 


\subsection{Stenodactylina burgundiaca (Crônier and Courville, 2004)}

Fig. 17E-I

Eryma burgundiaca Crônier and Courville, 2004: 1004, fig. 3, pl. 1, fig. 1.-Garassino and Schweigert, 2006: 8. - Feldmann and Titus, 2006: 63.

Eryma burgundiacum-Schweitzer et al., 2010: 23.

Stenodactylina burgundiaca-Devillez et al., 2016: 524.

Type material. - Holotype UR ON10Cr1.

Type locality. - «Les Minières», Etrochey, Côte d'Or departement, Bourgogne, France.

Type age.-Callovian, Middle Jurassic.

Description.

Carapace. - Sub-cylindrical carapace; deep cervical groove, slightly inclined, joined to dorsal margin and to antennal groove; deep antennal groove; short, deep gastro-orbital groove, originating as a slight median inflexion of cervical groove; postcervical and branchiocardiac grooves subparallel; deep, narrow postcervical groove, curved forward, not joined to dorsal margin and interrupted in hepatic region; narrow branchiocardiac groove, shallow dorsally, becoming wider and deeper toward its junction with the hepatic groove, not joined to dorsal margin, joined to the posterior extremity of hepatic groove; shallow hepatic groove, concavo-convex, joined to cervical groove; slightly inflated $\omega$ and $\chi$ areas, $\chi$ area delimited dorsally by a groove extending between hepatic and branchiocardiac grooves; deep inferior groove, joined to hepatic groove.

Thoracic appendages. - Chelate $\mathrm{P} 1 ; \mathrm{P} 1$ propodus elongated, subrectangular, slightly globose dorso-ventrally; inner margin more compressed than outer margin; inflated dactylar bulge.

Ornamentation. - Carapace densely covered by tubercles preceded by rounded depressions, the ornamentation is thinner and denser in cardiac and hepatic regions; $\mathrm{P} 1$ propodus densely covered by rounded tubercles preceded by depressions.

Discussion.-Eryma burgundiacum is known by a carapace and a P1 chela. Examination of the holotype reveals the absence of junction between the postcervical and branchiocardiac grooves. The postcervical groove is interrupted in the hepatic region while the branchiocardiac groove is joined to the posterior extremity of the sinuous hepatic groove. This carapace groove pattern is typical of Stenodactylina. So, we concur with Devillez et al. (2016), who considered this species to be a representative of this genus.

Stenodactylina burgundiaca exhibits a dense, uniform ornamentation made of tubercles preceded by depressions. This kind of ornamentation is relatively common among the erymid lobsters, but the absence of coarser tubercles and of any row allows the distinction between this species and S.deslongchampsi, S. falsani, S. lagardettei, S. liasina, S. rogerfurzei $S$. spinosa and $S$. walkerae. Both $\omega$ and $\chi$ areas are inflated in S. burgundiaca, contrary to S. deslongchampsi and S. walkerae. However, $\omega$ area is les inflated than in S. guisei.

\subsection{Stenodactylina walkerae (Feldmann and Haggart, 2008)}

Fig. 17J-K

Eryma walkerae Feldmann and Haggart, 2008: 1792, fig. 2.-Schweitzer et al., 2010: 25.
Stenodactylina walkerae-Devillez et al., 2016: 524; 2017 : 792.

Type material. - Holotype RBCM.EH2007.005.0001.

Type locality.-McDonnell Lake, British Columbia, Canada.

Type age.-Bajocian-Callovian, Middle Jurassic.

Description.

Carapace. - Sub-cylindrical carapace; orbital notch slightly curved; narrow post-orbital area; deep, wide cervical groove, strongly curved, joined to dorsal margin and to antennal groove; narrow antennal groove; short gastro-orbital groove, originating as a slight median inflexion of cervical groove; inferior gastro-orbital lobe inflated; deep postcervical and branchiocardiac grooves, subparallel; narrow postcervical groove, slightly curved forward, joined to dorsal margin and interupted in hepatic region; branchiocardiac groove as wide as postcervical groove, joined to dorsal margin and to hepatic groove; shallow hepatic groove, concavo-convex, joined to cervical groove; inflated $\omega$ area; flat $\chi$ area; deep, wide inferior groove, joined to hepatic groove.

Ornamentation.-Carapace densely covered by small tubercles; gastric region with an orbital row supported by an oblique carina; antennal region with an antennal spine.

Discussion.-Eryma walkerae is known by a single carapace. Later, Devillez et al. (2016) have assigned the species to Stenodactylina. It is justified because of the short gastro-orbital groove, the absence of junction between the postcervical and branchiocardiac grooves, the interruption of the postcervical groove in the hepatic region, and the sinuous hepatic groove.

Stenodactylina walkerae is currently the oldest erymid species reported from North America. It is the only representative of the genus to have an orbital carina. Moreover, there is no orbital row in S. burgundiaca, S. deslongchampsi and $S$. guisei contrary to $S$. walkerae. There are no depressions in the ornamentation of $S$. walkerae contrary to S. burgundiaca, S. guisei and S.lagardettei. The postcervical and branchiocardiac grooves of $S$. walkerae are less curved than those of S. burgundiaca.

\section{Conclusions}

After this study of the erymid lobsters of the Early and Middle Jurassic, 25 species within four genera (Eryma Meyer, 1840a, Palaeastacus Bell, 1850, Pustulina Quenstedt, 1858, Stenodactylina) are recognised to be valid. With the exception of Eryma ventrosum (Meyer, 1835), which is present in the Middle Jurassic, but with a type age in the Late Jurassic, all the erymid species of Early and Middle Jurassic age are described here. Among all these species, nine are reported in the Early Jurassic and sixteen in the Middle Jurassic.

With nine species, Stenodactylina is the most diversified genera, but Eryma ( 8 species, including E. ventrosum) is more common. Pustulina is known by only three fossils. These old representatives of the genus exhibits some particularities on their carapace compared to the species of the Late Jurassic and Cretaceous. Indeed, the hepatic groove of Pustulina sp., P. elegans and P.calloviensis becomes almost convex in its anterior part. Moreover, Pustulina sp. does not have a welldeveloped gastro-orbital groove and shows a strongly 


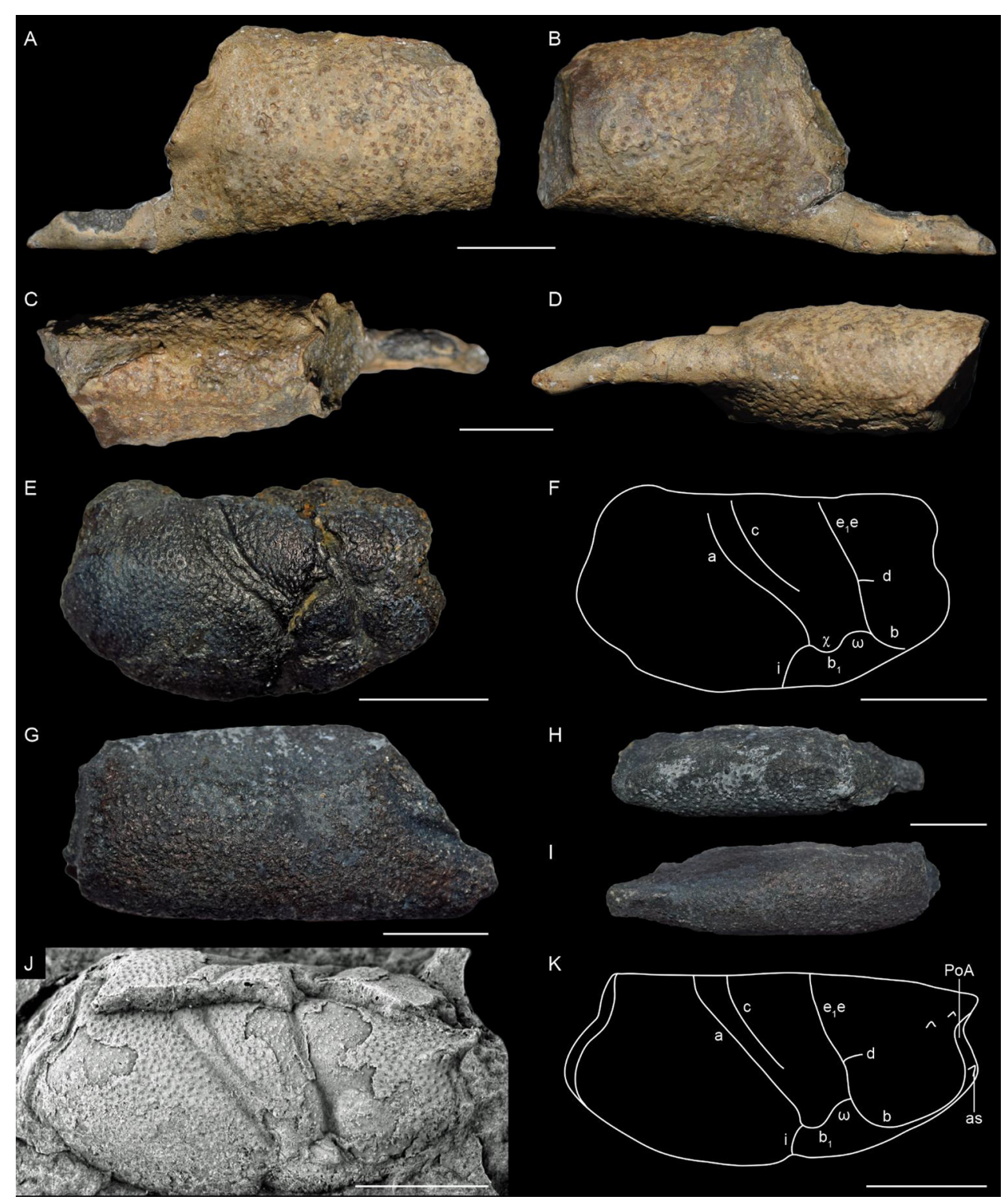

Fig. 17. Other species of Stenodactylina from Middle Jurassic. A-D: holotype SMNS 70043 of Stenodactylina rogerfurzei Schweigert, 2013 from the Aalenian of Scheffheu Hill (Germany): dorsal view (A), ventral view (B), inner view (C), outer view (D); E-F: holotype UR ON10Cr1 of Stenodactylina burgundiaca (Crônier and Courville, 2004) from the Callovian of Etrochey (France): general view (E), line drawing (F); G-I: additional specimen of S. burgundiaca UR without number: dorsal view (G), inner view (H), outer view (I); J-K: holotype of Stenodactylina walkerae (Feldmann and Haggart, 2008) from the Bajocian-Callovian of McDonnell Lake (United States): original figure of Feldmann and Haggart (2008: fig. 2) (J), line drawing (K). Scale bars: $1 \mathrm{~cm}$. Abbreviations: a: branchiocardiac groove; as: antennal spine; b: antennal groove; $b_{1}$ : hepatic groove; c: postcervical groove; $d$ : gastro- orbital groove; $\mathrm{e}_{1} \mathrm{e}$ : cervical groove; i: inferior groove; PoA: post-orbital area; $\chi$ : attachment site of adductor testis muscle; $\omega$ : attachement site of mandibular muscle. Photographs and line drawings: J. Devillez.

elongated branchiocardiac groove. $P$. calloviensis have also an inflated $\omega$ area. Such morphological features recall other erymid genera, like Eryma for example.

The presence of representatives of Eryma, Palaeastacus and Stenodactylina in Italy and Germany during the Sinemurian clearly suggests that an erymid fauna was already well- established in Western Europe at the beginning of the Jurassic. Moreover, all the fossils of erymid lobsters reported in Early Jurassic were found in Western Europe and almost all of the specimens of the Middle Jurassic: Eryma compressum (Eudes-Deslongchamps, 1842) was reported from Iran (Förster and Seyed-Emami, 1982) and Morocco (Secrétan, 1984), and Palaeastacus foersteri (Feldmann, 1979) n. comb. and Stenodactylina walkerae (Feldmann and Haggart, 2008) were found in North America. So, the extraEuropean erymid faunas are largely unknown and it is impossible to say if these lobsters spread out from Europe at the beginning of the Jurassic or if the European fauna was the result of previous migrations of populations from other areas. 


\section{Institutional abbreviations}

\begin{tabular}{|c|c|}
\hline AMNH & $\begin{array}{l}\text { American Museum of Natural His- } \\
\text { tory, New York (United States) }\end{array}$ \\
\hline $\mathrm{BM}$ & $\begin{array}{l}\text { Booth Museum of Natural History, } \\
\text { Brighton (United Kingdom) }\end{array}$ \\
\hline BSPG & $\begin{array}{l}\text { Bayerische Staatsammlung für Pal- } \\
\text { äontologie und Geologie, Munich } \\
\text { (Germany) }\end{array}$ \\
\hline CSMNF & $\begin{array}{l}\text { Museo di Paleontologia de l'Univer- } \\
\text { sità degli Studi di Napoli "Federico } \\
\text { II", Naples (Italy) }\end{array}$ \\
\hline FSL & $\begin{array}{l}\text { Université Claude Bernard Lyon 1, } \\
\text { Lyon (France) }\end{array}$ \\
\hline GPIT & $\begin{array}{l}\text { Fachbereichs Geowissenschafte, } \\
\text { Eberhard Karls Universität, Tübin- } \\
\text { gen (Germany) }\end{array}$ \\
\hline IRSNB & $\begin{array}{l}\text { Institut Royal des Sciences Naturelles } \\
\text { de Belgique, Bruxelles (Belgium) }\end{array}$ \\
\hline KGP-MH & $\begin{array}{l}\text { Katedra geológie a paleontológie, } \\
\text { Prírodovedecká fakulta, Univerzity } \\
\text { Komenského v Bratislave, Brati- } \\
\text { slava (Slovakia) }\end{array}$ \\
\hline MAN & Musée-aquarium, Nancy (France) \\
\hline MFN & $\begin{array}{l}\text { Museum für Naturkunde, Berlin } \\
\text { (Germany) }\end{array}$ \\
\hline MNHN.F & $\begin{array}{l}\text { Muséum national d'Histoire nature- } \\
\text { lle, Paris (France) }\end{array}$ \\
\hline MSNM & $\begin{array}{l}\text { Museo di Storia Naturale di Milano, } \\
\text { Milan (Italy) }\end{array}$ \\
\hline NHMUK & $\begin{array}{l}\text { Natural History Museum, London } \\
\text { (United Kingdom) }\end{array}$ \\
\hline NMB & $\begin{array}{l}\text { Naturhistorisches Museum, Basel } \\
\text { (Switzerland) }\end{array}$ \\
\hline PF & $\begin{array}{l}\text { Musée Pierres Folles, Saint-Jean- } \\
\text { des-Vignes (France) }\end{array}$ \\
\hline PIM & $\begin{array}{l}\text { Paläontologisches Institut und Mu- } \\
\text { seum, Universität Zürich, Zurich } \\
\text { (Switzerland) }\end{array}$ \\
\hline RBCM & $\begin{array}{l}\text { Royal British Columbia Museum, } \\
\text { Victoria (Canada) }\end{array}$ \\
\hline SMNS & $\begin{array}{l}\text { Staatliches Museum für Naturkunde, } \\
\text { Stuttgart (Germany) }\end{array}$ \\
\hline UR & $\begin{array}{l}\text { Laboratoire de paléontologie de } \\
\text { l'Université de Rennes, Rennes } \\
\text { (France) }\end{array}$ \\
\hline
\end{tabular}

\section{Anatomical abbreviations}

$\begin{array}{ll}\text { Mxp3 } & \text { Third maxilliped } \\ \text { P1-5 } & \text { Pereiopods } 1 \text { to } 5 \\ \text { s1-6 } & \text { Somites } 1 \text { to } 6 \\ \chi & \text { Attachment site of adductor testis muscle } \\ \omega & \text { Attachment site of mandibular muscle }\end{array}$

Acknowledgments. The authors are gratefull to Philippe Courville and Damien Gendry (University of Rennes 1,
Rennes, France), Sandra Delaunay and Thibault Keinerknecht (Musée Aquarium, Nancy, France), Annelise Folie (Institut Royal des Sciences naturelles de Belgique, Bruxelles, Belgium) Claire Mellish (Natural History Museum, London, United Kingdom), Christian Neumann and Andreas Abele (Museum für Naturkunde, Berlin, Germany), Günter Schweigert (Staatliches Museum für Naturkunde, Stuttgart, Germany), Ingmar Werneburg (Eberhard Karls Universität, Tübingen, Germany) and Walter Etter (Naturhistorisches Museum, Basel, Switzerland) for the access to the fossils housed in the collections of their respective institutions. We also greatly thank Alessandro Garassino (Museo di Storia Naturale di Milano, Milan, Italy), Christian Klug (University of Zurich, Zurich, Switzerland) and Neil Landman, Bushra Hussaini and Stephen Thurston (American Museum of Natural History, New York, United States) for searching and supplying photographs of the specimens stored in the collections of their institutions. We also like to express our thanks to Lilian Cazes and Philippe Loubry (MNHN, Paris, France), Philipe Havlik (Eberhard Karls-Universität Tübingen, Germany), Ninon Robin (New Jersey Institute of Technology, Newark, United States), Matúš Hyžný (Comenius University, Bratislava, Slovakia), Denis Audo (Yunnan University, Kunming, China) for the photographs of some figured specimens. Finally, we address special thanks to Alessandro Garassino and Günter Schweigert who took the time to review this paper and share their constructive suggestions to improve this work.

\section{References}

Aguirre-Urreta MB. 1982. Crustaceos Decapodos Barremianos de la region del Tucu-Tucu, Provincia de Santa Cruz. Revista de la Asociación Paleontológica Argentina 19(3-4): 303-317.

Aguirre-Urreta MB. 1989. The Cretaceous decapod Crustacea of Argentina and the Antarctic Peninsula. Palaeontology 32(3): 499-552.

Aguirre-Urreta MB, Ramos VA. 1981. Crustaceos Decapodos del Cretacico Inferior de la Cuenca Austral, Provincia de Santa Cruz, Argentina. Comité Sudamericano del Jurásico y Cretácico: Cuencas sedimentarias del Jurásico y Cretácico de América del Sur 2: 599-623.

Astrop TI. 2011. Phylogeny and evolution of Mecochiridae (Decapoda: Reptantia: Glypheoidea): An integrated morphometric and cladistic approach. Journal of Crustacean Biology 31(1): 114-125.

Bachmayer F. 1959. Neue Crustaceen aus dem Jura von Stramberg (ČSR). Sitzungsberichte der Österreichischen Akademie der Wissenschaften, mathematisch-naturwissenschaftliche Klasse, Abteilung 1. Biologie, Mineralogie, Erdkunde, und verwandte Wissenschaften 168: 937-944.

Bean W. 1839. A catalogue of the fossils found in the Cornbrash Limestone of Scarborough. Magazine of Natural History 3: 57-62.

Bell T. 1850. Notes on the crustacea of the chalk formation. In : Dixon F, ed. The geology and fossils of the tertiary and cretaceous formations of Sussex. Londres: Longman, Brown, Green and Longmans, pp. 344-345.

Bell T. 1863. Crustacea of the gault and greensand. In : A monograph of the fossil malacostracous Crustacea of Great Britain, Part II. Londres: Palaeontographical Society Monograph.

Beurlen K. 1928. Die Decapoden des Schwäbischen Jura mit Ausnahme der aus den oberjurassischen Plattenkalken stammenden. Palaeontographica 70: 115-278. 
Beurlen K. 1933. Crustacea Decapoda aus den Tendaguru-Schichten. Palaeontographica Suppl. 7(2): 89-94.

Birshtein JA. 1956. Desyatinogie rakobrznye paleogena Fergany. Byulleten' Moskovskogo Obshchestva ispytatelei prirody 61: 63-75.

Birshtein JA. 1958. Ein Vertreter der ältesten Ordo der Crustacea Decapoda Protoclytiopsis antiqua gen. nov. sp. nov. aus dem Permo West-Sibiriens. Doklady Akademii Nauk, SSSR 122: $477-480$.

Bravi S, Garassino A, Bartiromo A, Audo D, Charbonnier S, Schweigert G et al. 2014. Middle Jurassic Monte Fallano Plattenkalke (Campania, southern Italy): First report on terrestrial plants, decapod crustaceans and fishes. Neues Jahrbuch für Geologie und Paläontologie Abhandlungen 272 (1): 79-107.

Bronn HG. 1849. Index Palaeontologicus oder übersicht der bis jetzt bekannten fossilen Organismen. Stuttgart: Schweizerbart.

Carter JE. 1886. On the decapod Crustaceans of the Oxford clay. The Quarterly Journal of the Geological Society of London 42: 542-559.

Charbonnier S, Garassino A, Pasini G. 2012. Revision of Mesozoic decapod crustaceans from Madagascar. Geodiversitas 34(2): 313-357.

Charbonnier S, Garassino A, Schweigert G, Simpson M. 2013. A worldwide review of fossil and extant glypheid and litogastrid lobsters (Crustacea, Decapoda, Glypheoidea). Mémoires du Muséum national d'Histoire naturelle 205: 304.

Charbonnier S, Garassino A, Schweigert G, Audo D, Fernandez S. 2014. New look at the lobster Eryma greppini, Oppel, 1861 (Crustacea, Decapoda, Erymidae) from the Middle Jurassic of France and Switzerland. Neues Jahrbuch für Geologie und Paläontologie-Abhandlungen 272(3): 331-339.

Charbonnier S, Audo D, Garassino A, Hyžný M. 2017. Fossil crustacea of Lebanon. Mémoires du Muséum national d'Histoire naturelle 210: 252.

Copeland MJ. 1960. Erymastacus bordenensis a new Mesozoic decapod from the Canadian Arctic. Geological Survey of Canada Bulletin 60: 55-57.

Crônier C, Courville P. 2004. A rich and highly endemic decapod crustacean fauna from the Middle Jurassic of north-east France. Palaeontology 47(4): 999-1014.

Devillez J, Charbonnier S. 2017. The genus Eryma Meyer, 1840 (Crustacea: Decapoda: Erymidae): New synonyms, systematic and stratigraphic implications. Bulletin de la Société géologique de France 188(3): 1-10.

Devillez J, Charbonnier S, Hyžný M, Leroy L. 2016. Review of the Early Cretaceous erymid lobsters (Crustacea: Decapoda) from the Western Tethys. Geodiversitas 38(4): 515-541.

Devillez J, Charbonnier S, Kocová Veselská M, Pezy J-P. 2017. Review of the Late Cretaceous erymid lobsters (Crustacea: Decapoda) from the Western Tethys. Proceedings of the Geologists' Association 128: 779-797.

Devillez J, Charbonnier S, Pezy J-P. 2018. First Jurassic occurrence of Enoploclytia M'Coy, 1849 (Crustacea: Decapoda: Erymidae). Annales de Paléontologie 104: 143-148.

Dumortier E. 1867. Études paléontologique sur les dépôts jurassiques du Bassin du Rhône, deuxième partie, Lias Inférieur. Paris : F. Savy.

Étallon A. 1859. Description des crustacés fossiles de la Haute-Saône et du Haut-Jura. Bulletin de la Société géologique de France 16: 169-205.

Étallon A. 1861. Notes sur les crustacés jurassiques du bassin du Jura. Recueil agronomique, industriel et scientifique publié par la Société d'Agriculture de la Haute- Saône 9: 129-171.
Etheridge Jr. R. 1914. The genus Enoploclytia in the Cretaceous rocks of Queensland. Records of the Australian Museum 10: 271-273.

Etter W. 2004. Decapod crustaceans from the Middle Jurassic Opalinus Clay of northern Switzerland, with comments on crustacean taphonomy. Eclogae Geologicae Helvetiae 97: 381-392.

Eudes-Deslongchamps E. 1842. Mémoire pour servir à l'histoire naturelle des Crustacés fossiles. Mémoire de la Société Linnéenne de Normandie 7: 53-60.

Eudes-Deslongchamps E. 1878. Études paléontologiques des divers niveaux jurassiques de la Normandie comprenant la description et l'iconographie de tous les fossiles vertébrés et invertébrés qu'ils renferment, Vol. 2. Paris : Savy.

Fabricius JC. 1775. Systema entomologiae: sistens insectorum classes, ordines, genera, species, adiectis synonymis, locis, descriptionibus, observationibus. Flansburgi and Lipsiae.

Fantescu OD, Feldmann RM, Schweitzer CE, Lazär L, Stoica M. 2018. New lobsters and lobster-like decapods (Crustacea) from the Jurassic and Cretaceous of Romania. Neues Jahrbuch für Geologie und Paläontologie-Abhandlungen 287(1): 45-60.

Feldmann RM. 1979. Eryma foersteri, a new species of lobster (Decapoda) from the Jurassic (Callovian) of North America. American Museum Novitates 2668: 1-5.

Feldmann RM, Copeland MJ. 1988. A new species of erymid lobster from Lower Jurassic strata (Sinemurian/Pliensbachian), Fernie Formation, Southwestern Alberta. Contributions to Canadian Paleontology 379: 93-101.

Feldmann RM, Haggart JW. 2008. A new species of lobster (Astacidea, Erymidae) from the Smithers Formation (Middle Jurassic) of British Columbia, Canada. Canadian Journal of Earth Sciences 44: 1791-1796.

Feldmann RM, McPherson CB. 1980. Fossil decapod crustaceans of Canada. Geological Survey of Canada Paper 79-16: 1-20.

Feldmann RM, Schweitzer CE. 2013. A new Early Jurassic lobster (Decapoda: Glypheoidea: Glypheidae) from Lyme Regis, England. Bulletin of the Mizunami Museum 39: 1-5.

Feldmann RM, Titus AL. 2006. Eryma jungostrix n.sp. (Decapoda; Erymidae) from the Redwater Shale of the Stump Formation (Jurassic; Oxfordian) of Utah. Journal of Crustacean Biology 26 (1): 63-68.

Feldmann RM, Crisp G, Pirrie D. 2002. A new species of glypheoid lobster, Pseudoglyphea foersteri (Decapoda: Astacidea: Mecochiridae) from the Lower Jurassic (Pliensbachian) of Raasay, Inner Hebrides, UK. Palaeaontology 45(I): 23-32.

Feldmann RM, Schweitzer CE, Karasawa H. 2015. Crustacea. In : Selden PA, ed. Treatise online, Part R (Revised), Arthropoda 4(1), Chapter 8I, pp. 1-28.

Ferry M. De 1861. Note sur l'étage Bajocien des environs de Mâcon (Saône et Loire). Mémoires de la Société Linnéenne de Normandie 12: $1-46$.

Ferry M. De 1865 . Note sur les crustacés et les spongiaires de la base de l'étage Bathonien des environs de Mâcon. Bulletin de la Société linnéenne de Normandie 9: 365-376.

Fischer JC. 2003. Invertébrés remarquables du Callovien inférieur de la Voulte-sur-Rhône (Ardèche, France). Annales de Paléontologie 89: 223-252.

Förster R. 1966. Über die Erymiden, eine alte konservative Familie der mesozoischen Dekapoden. Palaeontographica A125(4-6): 61-175.

Förster R. 1971. Die Mecochiridae, eine spezialisierte Familie der mesozoischen Glypheoidea (Crustacea, Decapoda). Neues Jahrbuch für Geologie und Paläontologie-Abhandlungen 137(3): 396-421. 
Förster R, Rieber H. 1982. Der älteste Vertreter der Gattung Palaeastacus (Crustacea, Decapoda), Palaeastacus argoviensis n. sp., aus dem unteren Dogger der Nordschweiz. Eclogae geologicae Helvetiae 75(3): 773-778.

Förster R, Seyed-Emami K. 1982. First occurrence of Eryma bedelta (Quenstedt) (Crustacea, Decapoda) from the Aalenian of Iran. Mitteilungen der Bayerischen Staatssammlung für Paläontologie und historische Geologie 22: 41-45.

Fox-Strangeways C. 1892. The Jurassic rocks of Britain. Vol.2, Yorkshire-Tables of fossils. Londres: Eyre and Spottiswoode.

Frentzen K. 1937. Über einige Decapoden aus dem Lias Delta Schwabens. Beiträge zur naturkundlichen Forschung in Südwestdeutschland 2(1): 106-115.

Garassino A. 1994. The macruran decapod crustaceans of the Upper Cretaceous of Lebanon. Paleontologia Lombarda, nuova serie 3: $1-27$.

Garassino A. 1996. The family Erymidae Van Straelen, 1924 and the superfamily Glypheoidea Zittel, 1885 in the Sinemurian of Osteno in Lombardy (Crustacea, Decapoda). Atti della Società italiana di Scienze naturali e del Museo civico di Storia naturale in Milano 135: 333-373.

Garassino A, Krobicki M. 2002. Galicia marianae n. gen., n. sp. (Crustacea, Decapoda, Astacidea) from the Oxfordian (Upper Jurassic) of the Southern Polish Uplands. Bulletin of the Mizunami Fossil Museum 29: 51-59.

Garassino A, Rigo R. 2008. Pseudoglyphea friulana n. sp. (Decapoda, Astacidea, Mecochiridae) from the Upper Triassic (Carnian) of Dogna (Udine, Friuli-Venezia Giulia, NE Italy). Atti della Societá italiana di Scienze naturali e del Museo civico di Storia natural in Milano 149(1): 69-76.

Garassino A, Schweigert G. 2006. The Upper Jurassic Solnhofen decapod crustacean fauna: review of the types from old descriptions. Part I. Infraorders Astacidea, Thalassinidea and Palinura. Memorie della Società italiana di Scienze naturali e del Museo civico di Storia naturale di Milano 34(1): 1-64.

Glaessner MF. 1929. Crustacea Decapoda. In: Pompeckj JF, ed. Fossilium Catalogus, I: Animalia, Pars 41, pp. 1-464.

Glaessner MF. 1931. Eine Crustaceenfauna aus den Lunzer Schichten Niederösterreichs. Jahrbuch der Geologischen Bundesanstalt 81 (3-4): 467-486.

Glaessner MF. 1969. Decapoda. In: Moore RC, ed. Treatise on Invertebrate Paleontology, Part R, Arthropoda 4(2), pp. 399-533.

Harbort E. 1905. Die Fauna der Schaumburg-Lippeschen Kreidemulde. Abhandlungen der Preussischen Geologischen Landesanstalt, Neue Folge 45: 10-22.

Hauff B. 1953. Das Holzmadenbuch. Öhringen: Rau.

Hée A. 1924. Catalogue critique des crustacés jurassiques du Calvados et de l'Orne. Bulletin de la Société linnéenne de Normandie 7(6): 126-157.

Hyžný M, Schlögl J, Charbonnier S, Schweigert G, Rulleau L, Gouttenoire M. 2015. Intraspecific variation and taphonomy of a new erymid lobster (Crustacea: Decapoda) from the Middle Jurassic of Belmont (Beaujolais, France). Geobios 48: 371-384.

ICZN. 1999. International Code of Zoological Nomenclature. International Trust for Zoological Nomenclature. Londres: The Natural Museum, v-xxix, pp. 1-306.

Ilyin IV. 2000. Histoire de l'étude des décapodes fossiles du Cénozoïque et du Mésozoïque de l'Eurasie du Nord. Proceedings of the Undergraduate and Postgraduate Student International Conference on Fundamental Sciences 5: 151-156.

Jagt WM, Fraaije RHB. 2002. The erymid lobster Enoploclytia leachii (Mantell, 1822) from the Upper Campanian of northeast
Belgium. Bulletin de l'Institut royal des sciences naturelles de Belgique, Sciences de la Terre 72: 91-95.

Joleaud L, Hsu T- Y. 1935. Crustacés décapodes du Crétacé de Tanout (Damergou, Niger français). Archives du Muséum national d'Histoire naturelle 13(6): 99-110.

Karasawa H, Ohara M, Kato H. 2008. New records for Crustacea from the Arida Formation (Lower Cretaceous, Barremian) of Japan. Boletín de la Sociedad Geológica Mexicana 60(1): 101-110.

Karasawa H, Schweitzer CE, Feldmann RM. 2013. Phylogeny and systematics of extant and extinct lobsters. Journal of Crustacean Biology 33(1): 78-123.

Kato H, Takahashi T, Taira M. 2010. Late Jurassic decapod crustaceans from northeast Japan. Palaeontology 53(4): 761-770.

Klompmaker AA, Fraaije RHB. 2011. The oldest (Middle Triassic, Anisian) lobsters from the Netherlands: Taxonomy, taphonomy, paleoenvironment, and paleoecology. Palaeontologia Electronica 14(1): 1-16.

Krause HPG. 1891. Die Decapoden des norddeutschen Jura. Zeitschrift der Deutschen Geologischen Gesellschaft 43: 171-225.

Lahusen J. 1894. Über die russischen Krebsreste aus den jurassischen Ablagerungen und der unteren Wolgastufe. Verhandlungen der Russischen Kaiserlichen Mineralogischen Gesellschaft 31(2): 313-324.

Latreille PA. 1802. Histoire naturelle, générale et particulière des crustacés et des insectes. Tome 3. Paris : Dufart.

Lissajous M. 1923. Étude sur la faune du Bathonien des environs de Mâcon : mémoire posthume. Première partie. Lyon: Laboratoire de Géologie de l'Université de Lyon.

Mantell GA. 1824. Outlines of the natural history, of the environs of Lewes. In : Horsfield TW, ed. The History and antiquities of Lewes and its vicinity. Lewes: J. Baxter.

Mantell GA. 1833. The geology of the South-East of England. Londres: Longman, Rees, Orme, Brow, Green and Longman.

Martill DM. 1991. Other invertebrates. In: Martill DM, Hudson JD, eds. Fossils of the Oxford Clay. Londres: The Palaeontological Association.

Méchin A. 1901. Sur quelques formes nouvelles du genre Eryma (Astacomorpha fossiles) du Jurassique de Lorraine. Bulletin des Séances de la Société des Sciences de Nancy 3(2): 73-84.

Mertens H. 1833. Beobachtungen und Untersuchungen über die Beroëartigen Akalephen. Mémoires de l'Académie impériale des sciences de St.-Pétersbourg 6(2): 479-543.

Mertin H. 1941. Decapode Krebse aus dem subhercynen und Braunschweiger Emscher und Untersenon. Nova Acta Leopoldina 68(10): 149-264.

Meyer H. von 1835. Briefliche Mittheilungen. Neues Jahrbuch für Mineralogie, Geognosie, Geologie und Petrefactenkunde 328-329.

Meyer H. von 1840a. Briefliche Mittheilungen. Neues Jahrbuch für Mineralogie, Geognosie, Geologie und Petrefactenkunde 576-587.

Meyer H. von 1840b. Neue Gattungen fossiler Krebse aus Gebilden vom bunten Sandstein bis in die Kreide. Stuttgart: Schweizerbart.

Monaco P, Garassino A. 2000. Burrows and body fossil of decapod crustaceans in the Calcari Grigi, Lower Jurassic, Trento Platform (Italy). Geobios 34(3): 291-301.

Morière J. 1883. Note sur quelques crustacés fossiles. Bulletin de la Société linnéenne de Normandie 4(2): 136-143.

Morière J. 1888. Note sur quelques crustacés fossiles. Bulletin de la Société Linnéenne de Normandie 4(1): 137-143.

Münster G, Graf Zu. 1839. Decapoda Macrura. Abbildung und Beschreibung der fossilen langschwänzigen Krebse in den Kalkschiefern von Bayern. Beiträge zur Petrefaktenkunde 2: 1-88. 
Oppel A. 1853. Der mittlere Lias Schwabens. Stuttgart: Ebner and Seubert.

Oppel A. 1854. Der mittlere Lias Schwabens. Jahreshefte des Vereins für vaterländische Naturkunde in Württemberg 10: 39-136.

Oppel A. 1861. Die Arten der Gattungen Eryma, Pseudastacus, Magila und Etallonia. Jahreshefte des Vereins für vaterländische Naturkunde in Württemberg 17: 355-361.

Oppel A. 1862. Ueber jurassische Crustaceen (Decapoda Macrura). Palaeontologische Mittheilungen aus dem Museum des koeniglich Bayerischen Staates 1: 1-120.

Phillips J. 1875. Illustration of the geology of Yorkshire; or, a description of the strata and organic remains. In: Part I, The Yorkshire coast, 3rd ed. Londres: J. Murray.

Quenstedt FA. 1851. Das Flözgebirge Würtembergs: mit besonderer Rücksicht auf den Jura. Tübingen: H. Laupp.

Quenstedt FA. 1854. Ueber Mecochirus im braunen Jura $\zeta$ bei Gammelshausen und einige andere Krebse. Jahreshefte des Vereins für vaterländische Naturkunde in Württemberg 10: 186-361.

Quenstedt FA. 1856-1858. Der Jura. Tübingen: H. Laupp.

Quenstedt FA. 1867. Handbuch der Petrefaktenkunde, 2nd ed. Tübingen: H. Laupp.

Quenstedt FA. 1885. Handbuch der Petrefaktenkunde, 3rd ed. Tübingen: H. Laupp.

Rathbun MJ. 1923. Decapod Crustaceans from the Upper Cretaceous of North Carolina. North Carolina Geological and Economic Survey 5: 403-408.

Rathbun MJ. 1926. The fossil stalk-eyed crustacea of the Pacific Slope of North America. Smithsonian Institution United States National Museum Bulletin 138: 1-155.

Reuss AE. 1854. Über Klytia Leachi, einen langschwänzigen Decapoden der Kreideformation. Denkschriften der kaiserlichen Akademie der Wissenschaften 6: 1-10.

Roger J. 1946. Les invertébrés des couches à poissons du Crétacé supérieur du Liban. Mémoires de la Société Géologique de France 51: 1-92.

Schlotheim EF. von 1822. Beiträge zur näheren Bestimmung der versteinerten und fossilen Krebsarten. Nachträge zur Petrefaktenkunde. Gotha, Becker, pp. 17-37.

Schram FR, Dixon CJ. 2004. Decapod phylogeny: Addition of fossil evidence to a robust morphological cladistics data set. Bulletin of the Mizunami Fossil Museum 31: 1-19.

Schweigert G. 2013. A new record of the enigmatic lobster genus Stenodactylina Beurlen, 1928 (Crustacea: Decapoda: Erymidae) from the Middle Jurassic of south-western Germany. Paläontologische Zeitschrift 87: 409-413.

Schweitzer CE, Feldmann RM. 2001. New Cretaceous and Tertiary decapod crustaceans from western North America. Bulletin of Mizunami Fossil Museum 28: 173-210.

Schweigert G, Röper M. 2001. Neue Krebse der Gattung Palaeastacus (Crustacea: Decapoda: Erymidae) aus oberjurassischen Plattenkalken Süddeutschlands. Stuttgarter Beiträge zur Naturkunde, Serie B (Geologie und Paläontologie) 313: 1-10.

Schweigert G, Garassino A, Hall RL, Hauff RB, Karasawa H. 2003. The lobster genus Uncina Quenstedt, 1851 (Crustacea: Decapoda: Astacidea: Uncinidae) from the Lower Jurassic. Stuttgarter Beiträge zur Naturkunde, B 332: 1-43.

Schweitzer CE, Feldmann RM, Iuliana L. 2009. Fossil Crustacea (excluding Cirripedia and Ostracoda) in the University of
Bucharest collections, Romania, including two new species. Bulletin of the Mizunami Fossil Museum 35: 1-14.

Schweitzer CE, Feldmann RM, Garassino A, Karasawa H, Schweigert G. 2010. Systematic list of fossil decapod crustacean species. Crustaceana Monographs 10: 1-222.

Schweigert G, Fraaije R, Havlik P, Nützel A. 2013. New Early Jurassic hermit crabs from Germany and France. Journal of Crustacean Biology 33(6): 802-817.

Secrétan S. 1964. Les Crustacés décapodes du Jurassique supérieur et du Crétacé de Madagascar. Mémoires du Muséum national d'Histoire naturelle, Nouvelle série, Série C, Sciences de la Terre 14: $1-226$.

Secrétan S. 1972. L'évolution segmentaire squelettique des Crustacés supérieurs. In : 24th International Geological Congress, Canada, 1972, section 7, Paleontology, pp. 612-620.

Secrétan S. 1984. Présence d'Eryma bedelta (Crustacea Decapoda) dans le Bajocien du Maroc oriental. Geobios 17(4): 515-518.

Stenzel HB. 1945. Decapod Crustacea from the Cretaceous of Texas. Texas University Publications 4401: 401-476.

Taylor BJ. 1979. Macrurous Decapoda from the Lower Cretaceous of South-Eastern Alexander Island. British Antarctic Survey Scientific Reports 81: 1-39.

Trautschold H. 1866. Zur Fauna des russischen Jura. Bulletin de la Société Impériale des Naturalistes de Moscou 1: 1-24.

Van Straelen V. 1922. Les crustacés décapodes du Callovien de la Voulte-sur- Rhône (Ardèche). Comptes rendus des séances de l'Académie des Sciences, Paris 175: 1224-1226.

Van Straelen V. 1925. Contribution à l'étude des crustacés décapodes de la période jurassique. Mémoires de la Classe des Sciences de l'Académie royale de Belgique 7: 1-462.

Vega FJ, Garassino A, Jaime RZ. 2013. Enoploclytia tepeyacensis n. sp. (Crustacea, Decapoda, Erymidae) from the Cretaceous (Campanian) of Coahuila, NE Mexico. Boletín de la Sociedad Geológica Mexicana 65(2): 207-211.

Vialle A. 1948. Révision des décapodes jurassiques du Laboratoire de Géologie. Mémoire de DES présenté à la Faculté des Sciences de l'Université de Lyon, $70 \mathrm{p}$.

Whicher J, Collins JSH, Chandler RB, Dodge M, Davey S. 2016. The fossil macrurous Crustacean Glyphea from within Thalassinoides burrows in the Inferior Oolite Formation of Frogden Quarry, Oborne, Dorset, UK. Proceedings of the Geologists' Association 127: 189-195.

Woods H. 1925-1931. A monograph of the fossil macrurous crustacea of England. Londres: The Palaeontographical Society, pp. 1-122.

Woods JT. 1957. Macrurous Decapods from the Cretaceous of Queensland. Memoirs of the Queensland Museum 13(3): 155-175.

Woodward H. 1877. A catalogue of British fossil Crustacea with their synonyms and the range in time of each genus and order. Londres: Taylor and Francis.

Wright T. 1860. On the subdivisions of the Inferior Oolite in the South of England, compared with the equivalent beds of that formation on the Yorkshire coast. The Quaterly Journal of the Geological Society of London 16(1): 1-48.

Wright T. 1881. On a new Astacomorphous crustacean from the middle coral reef of Leckhampton Hill. Proceedings of th Cotteswold Naturalists' Field Club 8: 56-59.

Zittel KA. von 1885. Handbuch der Palaeontologie (Arthropoda, Decapoda) 1(2): 523-721.

Cite this article as: Devillez J, Charbonnier S. 2019. Review of the Early and Middle Jurassic erymid lobsters (Crustacea: Decapoda), BSGF - Earth Sciences Bulletin 190: 6. 